NAYARA GOMES LUIZ SANTOS

\title{
DESENVOLVIMENTO DE UM MÉTODO DE IMUNOFLUORESCÊNCIA APLICADO À DETECÇÃO DE ANTICORPOS CONTRA O ARBOVÍRUS MAYARO
}

Dissertação apresentada ao Programa de PósGraduação Interunidades em Biotecnologia USP/ Instituto Butantan/IPT, para obtenção do Título de Mestre em Biotecnologia. 
NAYARA GOMES LUIZ SANTOS

\title{
DESENVOLVIMENTO DE UM MÉTODO DE IMUNFLUORESCÊNCIA APLICADO À DETECÇÃO DE ANTICORPOS CONTRA O ARBOVÍRUS MAYARO
}

\begin{abstract}
Dissertação apresentada ao Programa de Pós-Graduação Interunidades em Biotecnologia USP/ Instituto Butantan/IPT, para obtenção do Título de Mestre em Biotecnologia.

Área de concentração: Biotecnologia

Orientador: Dr. Renato Mancini Astray

Versão corrigida. A versão original eletrônica encontrase disponível tanto na Biblioteca do ICB quanto na Biblioteca Digital de Teses e Dissertações da USP (BDTD).
\end{abstract}

SÃO PAULO

2017 


\section{CATALOGAÇÃO NA PUBLICAÇÃO (CIP) Serviço de Biblioteca e informação Biomédica do Instituto de Ciências Biomédicas da Universidade de São Paulo}

Ficha Catalográfica elaborada pelo(a) autor(a)

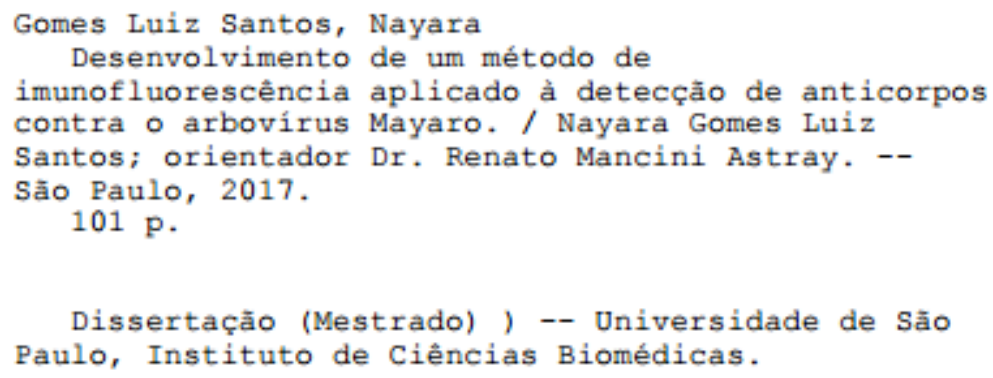

1. Virus Mayaro. 2. Imunofluorescência indireta. 3. Diagnóstico. 4. Células S2 de Drosophila melanogaster. 5. Expressão recombinante de proteinas. I. Mancini Astray, Dr. Renato, orientador. II. Título. 


\section{UNIVERSIDADE DE SÃO PAULO \\ Programa de Pós-Graduação Interunidades em Biotecnologia}

Universidade de São Paulo, Instituto Butantan, Instituto de Pesquisas Tecnológicas

Candidato(a): Nayara Gomes Luiz Santos

Título da Dissertação: Desenvolvimento de um método de imunofluorescência aplicado à detecção de anticorpos contra o arbovírus Mayaro.

Orientador(a): Dr. Renato Mancini Astray

A Comissão Julgadora dos trabalhos de Defesa da Dissertação de Mestrado, em sessão pública realizada a ...................................., considerou
( ) Aprovado(a)
( ) Reprovado(a)

Examinador(a): Assinatura:

Nome:

Instituição:

Examinador(a): Assinatura:

Nome:

Instituição:.

Presidente: Assinatura:

Nome:

Instituição: 


\section{il butantan \\ Comissão de Ética no \\ Uso de Animais}

São Paulo, 18 de janeiro de 2017 CEUAX N 3308270416

Ilimo(a). Sr(a).

Responsável: Renato Mancini Astray

Area: Imunologia Viral

Equipe envolvida: Nayara Luiz Gomes Santos - executor (instituto Butantan); Renato Mancini Astray (orientador)

Titulo do projeto: "Desenvolvimento de método de imunofluorescència aplicado à detecçāo de anticorpos contra o arbovirus Mayaro".

Parecer Consubstanciado da CEUA IB

A Comissão de Etica no Uso de Animais da Instituto Butantan, na reuniăo de 09/01/2017, ANALISOU e APROVOU o protocolo de estudo acima referenciado. A partir desta data, é dever do pesquisador:

1. Comunicar toda e qualquer alteraçāo do protocolo.

2. Comunicar imediatamente ao Comitê qualquer evento adverso ocorrido durante o desenvolvimento do protocolo.

3. Os dados individuais de todas as etapas da pesquisa devem ser mantidos em local seguro por 5 anos para possivel auditoria dos órgãos competentes.

4. Relatórios parciais de andamento deverão ser enviados anualmente à CEUA até a conclusâo do protocolo.

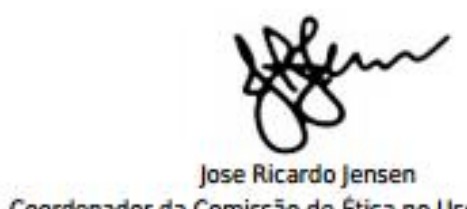

Coordenador da Comissäo de Ética no Uso de Animais Instituto Butantan

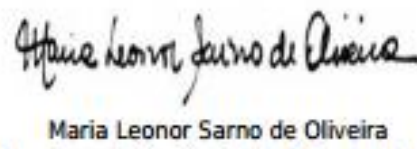

Vice-Coordenadora da Comissāo de Ética no Uso de Animais Instituto Butantan 


\section{ib butantan \\ Comissão de Ética no Uso de Animais}

Sảo Paulo, $18^{\text {th }}$ January 2017

\section{CERTIFIED}

We certify that the Research "Development of an immunofluorescence method for Mayaro infection diagnosis", protocol number CEUAx 3308270416, under the responsibility Renato Mancini Astray, agree with Ethical Principles in Animal Research adopted by Ethic Committee in the Use of Animals of Butantan Institute, and was approved in the meeting of day January 09, 2017.

Certificamos que o protocolo do Projeto de Pesquisa intitulado "Desenvolvimento de método de imunofluorescència aplicado à deteç̧āo de anticorpos contra o arbovirus Mayaro", protocolado sob o CEUAx n 3308270416, sob a responsabilidade de Renato Mancini Astray, está de acordo com os princípios éticos de experimentaçâo animal da Comissão de Ética no Uso de Animais da Instituto Butantan, e foi aprovado na reunião de 09 de janeiro de 2017.

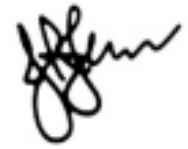

Jose Ricardo Jensen

Coordenador da Comissāo de Ética no Uso de Animais Instituto Butantan

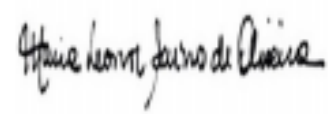

Maria Leonor Sarno de Oliveira

Vice-Coordenadora da Comissāo de Ética no Uso de Animais Instituto Butantan 
A Deus, por tão imenso amor e por permitir que este sonho se tornasse realidade. Aos meus amados pais Ana Maria Luiz e Amarildo Santos, aos quais devo tudo o que sou. 


\section{AGRADECIMENTOS}

\section{“Todo grande progresso da ciência resultou de uma nova audácia da imaginação" (John Dewey).}

A caminhada não seria fácil, e não foi, mas quem disse que isso deveria interromper um sonho? O que faz o trajeto valer a pena é a companhia de quem sempre acreditou em você. $\mathrm{E}$ a todos que, de alguma forma, contribuíram para o meu crescimento, o meu MUITO OBRIGADA!

A Deus, que por mim tem imensa misericórdia e amor, entregando seu filho amado Jesus Cristo na cruz para me salvar. A Este meu Salvador, melhor amigo, que me manteve de pé em todas as circunstâncias e fez meu sonho de chegar até aqui tornar-se realidade, meu eterno agradecimento.

Aos meus pais, que acreditaram e investiram no meu futuro, me guiaram no caminho de felicidade e me apoiaram nos momentos tristes e felizes, enxugando minhas lágrimas e me acompanhando nos risos. A quem devo tudo em que me tornei.

Ao meu amado e inesquecível Bhetwolven (in memorian), que me ensinou a simplicidade da felicidade, o sorriso fácil, o carinho quando necessário e a mais importante lição: que nada é para sempre, mas pode ser eterno enquanto dura.

Ao meu orientador Dr. Renato Mancini Astray, que mais do que professor e chefe, se fez amigo e conselheiro, a quem também devo tudo que aprendi. Obrigada pela paciência, cuidado, entrega e por acreditar em mim. Admiração e gratidão sempre ao melhor dos melhores.

À sempre atenciosa Dra. Soraia Attie Calil Jorge, por tantos momentos de aprendizado, ajuda, conselhos, co-orientação, afinal tantas discussões científicas ao seu lado me permitiram aprender ainda mais.

Aos meus QUERIDOS amigos do Laboratório de Imunologia Viral do Instituto Butantan, Ana Lia, Vera Boldorini, Mayra, Marcos, Fernanda, Sandra, Thaíssa, Daniella, Flávia, Alexandre, Deny, Dona Júlia, Denise, Silvana, Honorata, Lúcia, Leme e a todos os outros que por lá já passaram, tão amados quanto, que ajudaram a construir a profissional, mas, acima de tudo, o ser humano que sou hoje. Obrigada também pelos diversos momentos de descontração, tão importantes quando a angústia, incertezas e desafios pareciam grandes demais e até impossíveis de se alcançar.

À Dra. Alessandra Soares Schanoski, pela paciência, ensinamentos e compreensão no 
início de nosso trabalho, quando o mestrado ainda me exigia tempo e dedicação. À Cláudia Sossai, pelo companheirismo desde o primeiro momento.

Ao Instituo Butantan e ao Programa de Pós-Graduação Interunidades em Biotecnologia. A CNPq e FAPESP pelas bolsas de mestrado e treinamento técnico, investimento e suporte de projetos de pesquisa.

Um muito obrigada sempre será pouco para descrever minha gratidão. 
"E tudo quanto fizerdes, fazei-o de todo o coração, como para o Senhor e não para homens, conscientes de que recebereis do Senhor a recompensa da herança. É a Cristo, o Senhor, que estais servindo!" Colossenses 3:23, 24. 


\section{RESUMO}

SANTOS, N. G. L. Desenvolvimento de um método de imunofluorescência aplicado à detecção de anticorpos contra o arbovírus Mayaro. 2017. (101 f.). Dissertação (Mestrado em Biotecnologia) - Instituto de Ciências Biomédicas, Universidade de São Paulo, São Paulo, 2017.

O vírus Mayaro (MAYV) é um Alphavirus artritogênico responsável por causar uma doença febril aguda com sintomatologia parecida à da Dengue não-hemorrágica, porém com o agravante, igualmente à febre Chikungunya, de desenvolvimento de artralgia, a qual pode perdurar por meses ou anos, em alguns casos. Os dados epidemiológicos disponíveis ainda são poucos devido à falta de diagnóstico adequado, pois algumas das técnicas desenvolvidas apresentam dificuldades quanto à coleta de amostra, devido à curta viremia, e ao background que interfere na interpretação dos resultados, subestimando o real número dos casos de infecção principalmente em tempos de co-circulação de outras arboviroses também de impacto socioeconômico, como a própria Dengue e, mais recentemente, os vírus Zika e Chikungunya. A imunofluorescência é uma das metodologias mais utilizadas para o diagnóstico de infecções virais. Quando aplicada para a pesquisa de anticorpos direcionados a antígenos virais imunogênicos tem a capacidade de diagnosticar se o paciente já entrou em contato com um agente etiológico, mesmo que o período de viremia já tenha sido ultrapassado. Neste trabalho desenvolvemos um procedimento de imunofluorescência indireta dirigido ao diagnóstico da infecção pelo vírus Mayaro (MAYV) através da detecção de anticorpos contra a glicoproteína de membrana E2 do vírus. Primeiramente foi padronizada a metodologia de imunofluorescência indireta (IFI) direcionada à detecção de anticorpos contra a Glicoproteína do Vírus da Raiva (RVGP) em amostra de soro de camundongo e coelho, objetivando a reprodutibilidade da técnica para a detecção de anticorpos anti-E2 em amostras de soro de camundongos e humanos e, em seguida, obtivemos células de Drosophila melanogaster expressando E2 na membrana plasmática (S2MtMAYV(E3E2) e S2MtBipMAYV(E3E2V5)). Essas linhagens passaram por processos de seleções clonal e imunomagnética, dando origem às sub-linhagens S2MtMAYV(E3E2)_SC, S2MtBipMAYV(E3E2V5)_SC e S2MtMAYV(E3E2)_M1. A metodologia de IFI para RVGP foi aplicada para as linhagens recombinantes de MAYV utilizando soro hiperimune de camundongos e a sub-linhagem S2MtMAYV(E3E2)_SC, que apresentou a melhor relação de fluorescência por célula, foi testada, posteriormente, para amostras de soro humano com infecção confirmada para Mayaro e para os vírus Zika, Dengue e Chikungunya, permitindo a avaliação de possível reação cruzada. Análises de cinética de crescimento, em comparação com a linhagem selvagem, e de RT-qPCR, utilizando primers específicos de E2, foram realizadas para as linhagens originais e sub-linhagens em diferentes tempos de indução por $\mathrm{CuSO}_{4}$ e mostraram alcançar altas concentrações (ordem de $10^{7-} / \mathrm{mL}$ ) mesmo após 168 horas de indução, além do fato de que apresentaram menor quantidade de mRNA relativo à proteína E2 nos tempos 144 e 168 pós-indução, momentos em que a expressão da mesma na membrana foi maior. Os resultados obtidos com as células S2 expressando E2 na sua membrana confirmaram a utilidade da técnica de imunofluorescência indireta desenvolvida para o diagnóstico de infecção por MAYV, de forma que a aplicação de células S2 como suporte diagnóstico foi eficientemente avaliada. O teste também mostrou ser eficiente para diferenciar infecções por Alphavirus e Flavivirus, o que o torna ainda mais interessante em tempos de co-circulação de diversos arbovírus com sintomatologia semelhante.

Palavras-chave: Vírus Mayaro. Células S2. Expressão de proteína. Imunofluorescência. 


\begin{abstract}
SANTOS, N. G. L. Development of an immunofluorescence method applied to detection of antibodies against Mayaro arbovirus. 2017. (101 p). Masters thesis (Biotechnology) Instituto de Ciências Biomédicas, Universidade de São Paulo, São Paulo, 2017.

Mayaro virus (MAYV) is an arthritogenic Alphavirus responsible for causing an acute febrile illness with symptoms similar to non-hemorrhagic Dengue, but with the aggravation, as Chikungunya fever, to develop arthralgia, which can last for months or years, in some cases. The epidemiological data available still are few due to lack of proper diagnosis, because some of the techniques developed present difficulties regarding sample collection, due to the short viremia, and background that interferes on interpretation of the results, underestimating the actual number of infection cases especially in times of many other socioeconomic impact arboviruses, such as Dengue fever and, more recently, Zika and Chikungunya viruses. Immunofluorescence is one of the most widely used methods for the diagnosis of viral infections. When applied to the presence of antibodies directed to viral antigens imunogênicos has the ability to diagnose whether the patient came into contact with a causative agent, even if the period of viremia has already been exceeded. In this work we developed an indirect immunofluorescence procedure to the diagnosis of the Mayaro virus (MAYV) infection through the detection of antibodies against membrane E2 glycoprotein. First we standardized then methodology of indirect immunofluorescence (IFI) directed to the detection of antibodies against the Glycoprotein of rabies virus (RVGP) in mices and rabbits serum, aiming the reproducibility of technique for the detection of antibodies to E2 in mices and humans serum samples, and then, we obtained Drosophila melanogaster cells expressing E2 in the plasma membrane (S2MtMAYV (E3E2) and S2MtBipMAYV (E3E2V5)). These lineages were selected using clonal and immunomagnetic selection processes, giving rise to the sub-lineages S2MtMAYV (E3E2)_SC, S2MtBipMAYV(E3E2V5)_SC and S2MtMAYV(E3E2)_M1. The methodology of indirect immunofluorescence for RVGP was applied to MAYV recombinant population cells using hiperimmune mice serum and S2MtMAYV (E3E2)_SC sub-lineage, that presented the best cell fluorescence relation, was tested later for human serum samples confirmed to Mayaro infection and also to Zika, Dengue and Chikungunya viruses, allowing the evaluation of possible cross reaction. Growth kinetic analysis, comparing to the wild lineage, and RT-qPCR, using specific primers to E2, were taken to the original and subpopulations in different induction times using $\mathrm{CuSO} 4$ and reached high concentrations $\left(10^{7-}\right.$ $/ \mathrm{mL}$ ) even after 168 hours of induction, apart from the fact that showed reduced amount of relative mRNA to E2 protein in 144 and 168 hours after induction, when the glycoprotein expression in the membrane was higher. Results obtained to S2 cells expressing E2 in its membrane have confirmed the usefulness of the indirect immunofluorescence technique developed for diagnosing MAYV infection, so that the implementation of S2 cells support diagnosis was efficiently evaluated. The test also turned out to be efficient to differentiate Alphavirus and Flavivirus infections, which makes it even more interesting in co-circulation times of several arboviruses with similar symptoms.
\end{abstract}

Keywords: Mayaro Virus. S2 Cells. Protein expression. Immunofluorescence. 


\section{LISTA DE ABREVIATURAS E SIGLAS}

S2

Célula de Drosophila melanogaster (Schneider 2)

MAYV Vírus Mayaro

CHIKV Vírus Chikungunya

ZIKV Vírus Zika

DENV Vírus Dengue

RRV Vírus Ross River

BFV Vírus Barmah Forest

SFV Vírus Semliki Forest

UNA Vírus UNA

ORF Open Reading Frame

RER Retículo Endoplasmático Rugoso

RVGP Glicoproteína do Vírus da raiva

IH Hemaglutinação

FC Fixação do Complemento

SN Soroneutralização

IFI Imunofluorescência Indireta

IgM Imunoglobulina M

IgG Imunoglobulina $\mathrm{G}$

$\mathrm{CuSO}_{4} \quad$ Sulfato de Cobre

PCR Reação em Cadeia da Polimerase

PRNT Neutralização por redução de placas de lise

RT-PCR Reação em Cadeia da Polimerase com transcriptase reversa

RT-qPCR Quantificação em Reação em Cadeia da Polimerase com transcriptase reversa

PBS Solução Tampão de Salina Fosfatada

mRNA RNA mensageiro 


\section{LISTA DE ILUSTRAÇÕES}

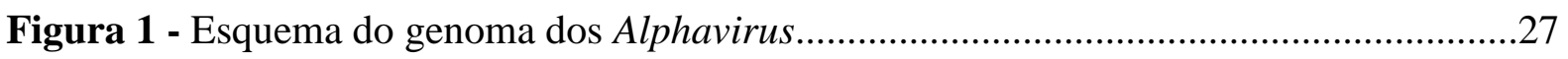

Figura 2 - O ciclo replicativo dos Alphavirus.................................................................28

Figura 3 - Distribuição de MAYV nas Américas do Sul e Central e Caribe............................30

Figura 4 - Ciclos enzoótico, rural e urbano do vírus Mayaro, baseando-se nos possíveis vetores e hospedeiros vertebrados. .30

Figura 5 - Patogênese de Alphavirus indutor de artrite/miosite..............................................35

Figura 6 - Gene sintético gBlock contendo as proteínas E3 e E2 do MAYV com os sítios de enzimas de restrição. . .45

$\begin{array}{lllllll}\text { Figura } & 7 & - & \text { Mapa } & \text { do } & \text { vetor } & \text { pGEM®-T }\end{array}$

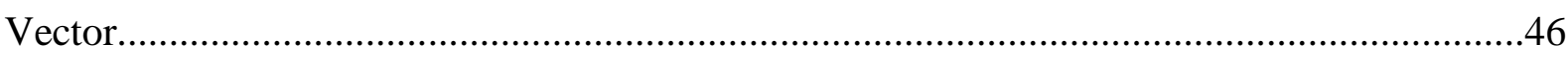

Figura8: Mapa dos vetores pMT/V5-HisA e pMT/Bip/V5-HisC........................................49

Figura 9 - Região de polylinker de pMtBip/V5-HisC ..........................................................50

Figura 10 - Princípio da técnica de separação imunomagnética.............................................54

Figura 11: Análise em gel de agarose 1,5\%. Amplificação do gene sintético por PCR Convencional.

Figura 12 - Análise em gel de agarose 1,5\%. PCR das colônias positivas para a transformação com o vetor pGEMMAYV(E3E2V5).

Figura 13 - Análise em gel de agarose 0,8\%. Confirmação da clonagem do vetor pGEMMAYV(E3E2V5) após transformação e amplificação em bactéria (Miniprep)

Figura 14 - Análise em gel de agarose 0,8\%. Confirmação da clonagem do vetor pGEMMAYV(E3E2V5) após purificação (Maxiprep).

Figura 15 - Análise em gel de agarose 0,8\%. Digestão dos vetores pMT/V5-HisA e pMTBip/v5-HisC e retirada do inserto de pGEMMAYV(E3E2V5).....................................64

Figura 16 - PCR Convencional de colônias.........................................................................64

Figura 17 - Confirmação da clonagem do vetor pMTMAYV(E3E2V5) por padrão de digestão com enzimas de restrição. 65

Figura 18 - Confirmação da construção do vetor pMTMAYV(E3E2V5) após purificação (Maxiprep) .66 
Figura 19 - PCR Convencional de colônias para identificação dos clones positivos para a construção do vetor pMtBipMAYV(E3E2).

Figura 20 - Análise em gel de agarose 0,8\%. Confirmação da clonagem do vetor pMtBipMAYV(E3E2V5) após purificação (Miniprep).

Figura 21 - Análise em gel de agarose 0,8\%. Confirmação da construção do vetor pMtBipMAYV(E3E2V5) após purificação (Maxiprep).

Figura 22 - Análise em gel de agarose $0,8 \%$. Confirmação da retirada do fragmento de 61 nucleotídeos após digestão enzimática com BglII .68

Figura 23 - Teste de fixação com solução de Metanol/Acetona $1: 1$........................................70

Figura 24 - Teste de fixação com solução de formaldeído a $2 \%$ e a $4 \%$................................71

Figura 25 - Teste de fixação com Metanol/Acetona $1: 1$ a $-20^{\circ} \mathrm{C}$ .72

Figura 26 - Teste de fixação Metanol/Acetona $1: 1$ a $-20^{\circ} \mathrm{C}$ por 20 minutos para as linhagens S2 Selvagem, S2MtMAYV(E3E2) e S2MtBipMAYV(E3E2V5). .73

Figura 27 - Linhagens de células S2 recombinantes marcadas com soro não-imune e hiperimune anti-MAYV de camundongos nos tempos 144 e 168 horas pós-indução. 75

Figura 28 - Linhagem S2MtMAYV(E3E2)_SC incubada com soros humanos negativos e positivos para os arbovírus Mayaro, Chikungunya e Zika e anticorpo secundário anti-IgG humano FITC .78

Figura 29 - Linhagem S2MtMAYV(E3E2)_SC incubada com amostras de soro humano de fase aguda para infecção pelos arbovírus Mayaro ou Chikungunya e anticorpo secundário anti-IgM humano FITC. .80

FIGURA 30 - Teste de imunofluorescência para verificação de positividade do soro humano anti-Zika.

FIGURA 31 - Teste de diluição de amostras de soro humano de fases aguda e covalescente para infecção pelo vírus Mayaro. .82

FIGURA 32 - Cinética de crescimento de células S2 selvagem e recombinantes na presença de $\mathrm{CuSO}_{4}$ . .83 


\section{LISTA DE TABELAS}

Tabela 1 - Estados brasileiros com casos suspeitos notificados de febre

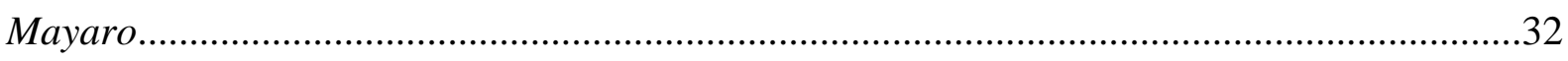

Tabela 2 - Dados epidemiológicos disponíveis da circulação do vírus Mayaro. 39

Tabela 3 - Sequência dos primers utilizados na PCR Convencional para confirmação da presença de inserto nas clonagens dos vetores genéticos. .48

Tabela 4 - Anticorpos primário e secundário utilizados na padronização e execução do

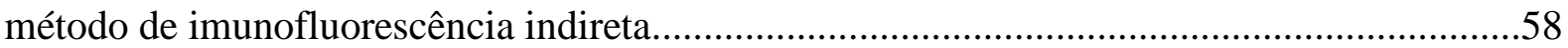

Tabela 5 - Linhagens de células S2 recombinantes estabelecidas para a expressão da glicoproteína E2 do vírus Mayaro 


\section{LISTA DE GRÁFICOS}

Gráfico 1 - Sinais e sintomas encontrados nos casos de doença febril por MAYV em Estados

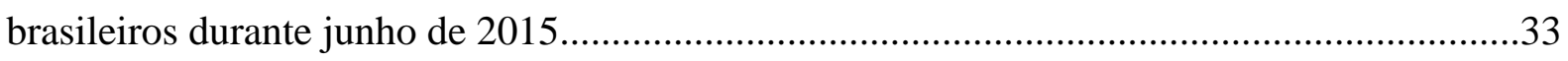

Gráfico 2 - mRNA relativo à glicoproteína E2 do vírus Mayaro nas subpopulações de células

$\mathrm{S} 2$ recombinantes em diferentes tempos de indução com $\mathrm{CuSO}_{4}$. 85 


\section{LISTA DE QUADROS}

Quadro 1 - Resumo da padronização inicial da técnica de imunofluorescência indireta para S2MtRCGPHy-M3, S2MtMAYV(E3E2) e S2MtBipMAYV(E3E2V5). 59 


\section{SUMÁRIO}

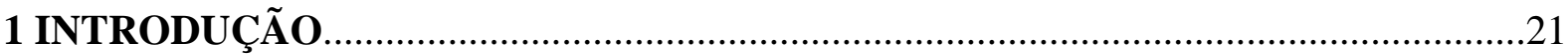

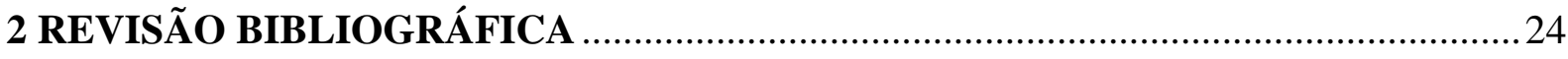

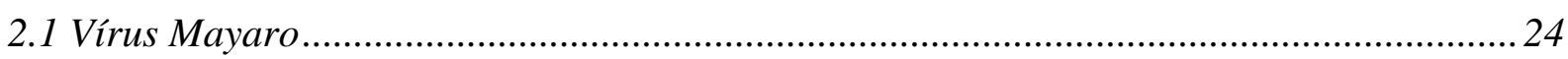

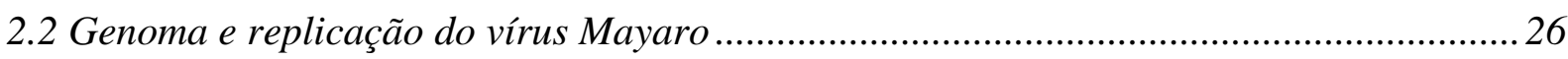

2.3 Transmissão e epidemiologia do vírus Mayaro ...................................................................2

2.4 Patogênese da doença febril por Mayaro e demais Alphavirus........................................ 34

2.5 Métodos de diagnóstico disponíveis para a detecção da infecção por Mayaro ................. 36

2.6 Células de Drosophila melanogaster (Schneider 2 - S2) como suporte de antígeno para o

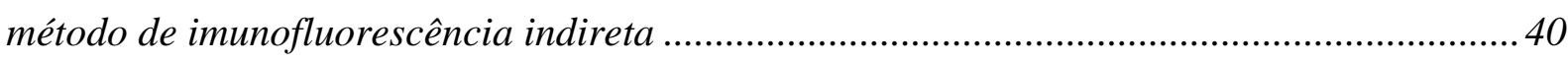

2.6.1 Métodos de seleção e enriquecimento populacional para células S2 ...........................42

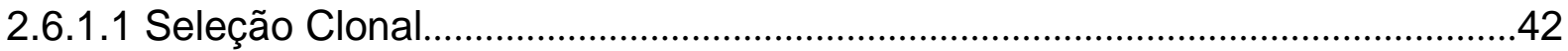

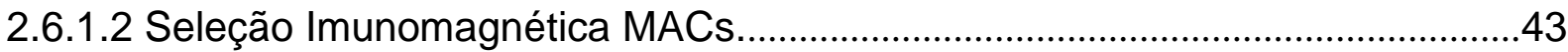

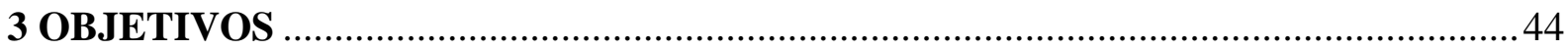

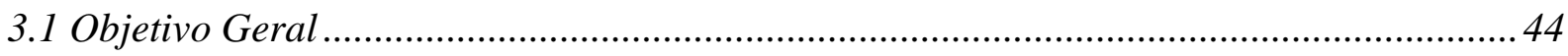

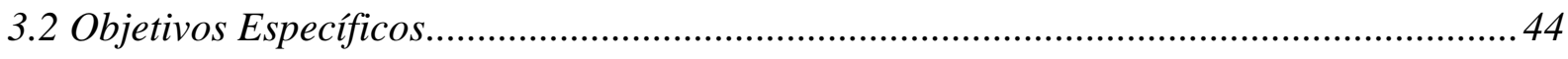

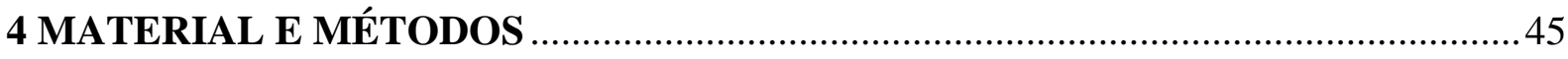

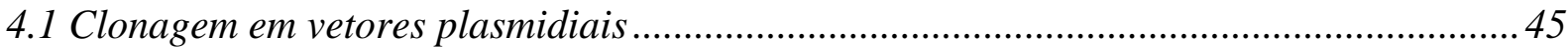

4.1.1 Gene sintético das proteínas E3 e E2 do vírus Mayaro (E3E2MAYV) ............................ 45

4.1.2 Amplificação e clonagem do gene sintético E3E2MAYV em vetor intermediário ........... 46

4.1.3 Bactéria utilizada nas etapas de construção ............................................................ 47

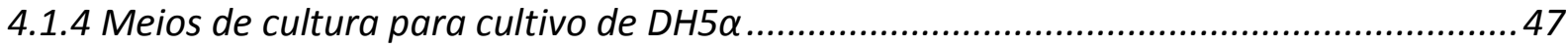

4.1.5 Deteç̧ão de colônias positivas por PCR Convencional ...............................................47

4.1.6 Miniprep - Lise Alcalina (adaptação da técnica de BIRNBOIM e DOLY, 1979) e Maxiprep

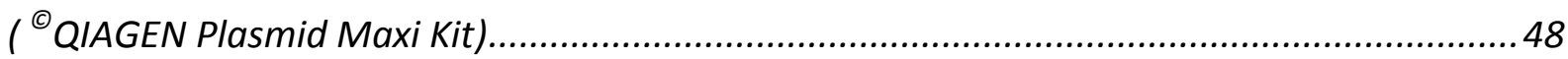

4.1.7 Clonagem do gene sintético nos vetores comerciais pMT/V5-HisA e pMT/BiP/V5-HisC

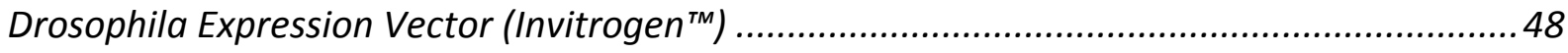

4.1.8 Análise de colônias transformadas por PCR e por padrão de digestão enzimática ........50

4.2 Obtenção de células S2MtMAYV(E3E2) e S2MtBipMAYV (E3E2V5)............................. 50

4.3 Métodos de seleção/ enriquecimento populacional das linhagens S2MtMAYV(E3E2) e

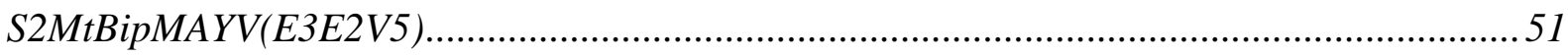


4.3.1 Seleção clonal das linhagens S2MtMAYV(E3E2) e S2MtBipMAYV(E3E2V5). .51

4.3.2 Enriquecimento populacional das linhagens S2MtMAYV(E3E2) e S2MtBipMAYV(E3E2V5) por seleção imunomagnética MACs. 53

4.4 Padronização da técnica de Imunofluorescência indireta utilizando como suporte de antígeno células $S 2$ expressando a glicoproteina do vírus da raiva (RVGP) e a glicoproteína E2 do vírus Mayaro 54

4.4.1 Estudo primário com células expressando a glicoproteína do vírus da raiva (RVGP).....54

4.4.2 Cultivo das células S2 recombinantes expressando RVGP/E2 e adesão às lamínulas ....55

4.4.2.1 Cultivo de células S2MtRVGPHy-M3..................................................55

4.4.2.2 Cultivo de células S2MtMAYV(E3E2) e S2MtBipMAYV(E3E2V5)................55

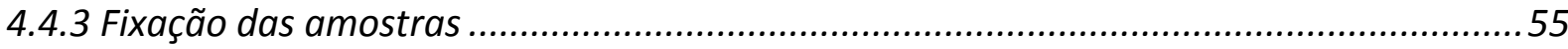

4.4.4 Marcação com anticorpos primários, secundários, soros de camundongos e humanos .56

4.4.5 Microscopia de fluorescência 58

4.5 Cinética de crescimento celular - células S2 Selvagem, S2MtMAYV(E3E2), S2MtBipMAYV(E3E2V5) e sub-linhagens 59

4.6 Quantificação relativa por RT-qPCR de RNA mensageiro (mRNA) da glicoproteína E2 de

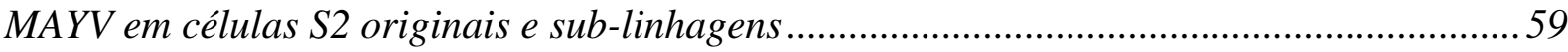

5 RESULTADOS 61

5.1 Obtenção do vetor intermediário pGEMMAYV(E3E2V5) 61

5.2 Obtenção dos vetores plasmidiais pMtMAYV(E3E2) e pMTBipMAYV(E3E2V5) 63

5.3 Estabelecimento das populações celulares 69

5.4 Padronização da técnica de Imunofluorescência Indireta. 70

5.4.1 Método de imunofluorescência indireta aplicado à deteç̧ão de anticorpos anti-Mayaro em amostras de soro de camundongos. 74

5.4.2 Método de Imunofluorescência Indireta aplicado à detecção de anticorpos antiMayaro, Chikungunya, Dengue e Zika em amostras de soro humano. 77

5.5 Cinética de crescimento celular 83

5.6 Quantificação relativa do mRNA da glicoproteina E2 de MAYV nas linhagens de células S2 recombinantes estabelecidas. .84 
6 DISCUSSÃO

7 CONCLUSÕES

REFERÊNCIAS*

ANEXOS

A - Procedimento de imunofluorescência indireta utilizando células S2 recombinantes como suporte antigênico

$\boldsymbol{B}$ - Procedimento de imunofluorescência indireta utilizando células $S 2$ recombinantes como suporte antigênico (quantidades de anticorpos primários e secundários ajustadas). 100

C - Recombinant S2 cell population enrichment impacts on specific RNA expression levels and on Rabies Virus Glycoprotein expression 101 


\section{INTRODUÇÃO}

Recentemente, alguns arbovírus têm sido determinados como importantes agentes de doenças emergentes no Brasil, como os vírus Dengue (DENV), Febre Amarela (YFV), Zika (ZKV), Chikungunya (CHIKV), West Nile (WNV), Mayaro (MAYV), Rocio, Saint Louis e Oroupoche. Dentre esses, até o ano de 2015, DENV, MAYV, YFV, Rocio, Saint Louis e Oroupoche eram os responsáveis por mais de $95 \%$ dos casos de infecção por arbovírus no Brasil, sendo DENV o mais prevalente, causando epidemias por 4 diferentes sorotipos (MARCONDES; XIMENES, 2015).

O principal vetor para as arboviroses em território brasileiro é o mosquito da espécie Aedes aegypti e, secundariamente, aparece a espécie Aedes albopictus. Ainda que seja conhecido há vários anos que os mosquitos do gênero Aedes sejam capazes de transmitir diversos arbovírus de importância médica em todo o mundo, durante os recorrentes surtos anuais de Dengue (DENV) nas últimas duas décadas, a possibilidade de introdução dos vírus Chikungunya (CHIKV) e Zika (ZIKV) foi negligenciada. Atualmente, a preocupação quanto às consequências clínicas e socioeconômicas decorrentes das infecções por arbovírus abrange, na sua grande totalidade, DENV, CHIKV, ZIKV. Os pesquisadores, por outro lado, têm começado a incluir também o vírus Mayaro (MAYV) nessa lista, devido aos surtos esporádicos cada vez mais crescentes e à sua já comprovada urbanização envolvendo as espécies de mosquito Cx. Quinquefasciatus e Aedes aegypti em cidades brasileiras. No entanto, o diagnóstico da infecção por MAYV ainda constitui um problema no atual cenário de co-circulação dos arbovírus CHIKV, ZIKV e DENV devido à baixa especificidade das técnicas sorológicas empregadas (FERNÁNDEZ-SALAS et al., 2016; SERRA et al., 2016; ZUCHI et al., 2014). Quanto ao impacto econômico na saúde pública gerado pelas arboviroses, este tem aumentado dramaticamente nos últimos 50 anos, pois essas doenças vêm alcançando novas localizações geográficas. O aumento atualmente observado na distribuição e intensidade dessas infecções é agravado pela indisponibilidade de antivirais ou vacinas (KRAEMER et al., 2015).

A febre Mayaro, como é chamada a doença por ele causada, não está associada à fatalidades e, embora mais leve do que a ocasionada por Dengue, pode ser uma doença mais debilitante mesmo após a primeira infecção. O aspecto mais proeminente da doença também é a artralgia severa, como ocorre com a infecção por CHIKV, que pode ocasionar alta perda de produtividade e sobrecarga dos serviços médicos públicos (MOTA et al., 2015). Por esta 
razão, existe a necessidade de soluções quanto ao controle de vetores e desenvolvimento de novas estratégias de diagnóstico, prevenção e tratamento das infecções transmitidas por Alphavirus causadores de artralgia . Os dados epidemiológicos da Febre Mayaro precisam ser melhor coletados e avaliados, o que permitiria um maior conhecimento da enfermidade (ASSUNÇÃO-MIRANDA et al., 2013; MOTA et al., 2015). Isto somente é possível a partir da existência de um ou mais métodos de diagnóstico complementares, sensíveis, específicos e diferenciais, capazes de detectar os casos de infecção mesmo em tempos de co-circulação de inúmeras arboviroses.

Neste trabalho desenvolvemos um método de imunofluorescência indireta, utilizando células de inseto recombinantes, que poderá ser utilizado como estratégia de diagnóstico de infecção por Alphavirus. Deve-se ressaltar que no início do trabalho ainda não havia a transmissão notável do vírus Chikungunya em território brasileiro, sendo apenas diagnosticado em casos importados. Esse fato resultou no direcionamento do objetivo da pesquisa para a obtenção de um método de diagnóstico diferencial apenas entre Alphavirus (Mayaro) e Flavivirus (Dengue). A técnica de imunofluorescência é um dos métodos mais frequentemente utilizados na área de diagnóstico clínico, tratando-se de uma técnica explorada há muitos anos, que permite a detecção de anticorpos circulantes no soro de pacientes e animais infectados e a diferenciação entre arboviroses (DUAN et al., 2012; TAPPE et al., 2009). O desenvolvimento de uma nova técnica de imunofluorescência para a detecção da infecção por MAYV/CHIKV poderia contribuir para o melhor acompanhamento do quadro clínico do paciente, oferecendo o tratamento mais adequado e registros epidemiológicos mais confiáveis, visto que os serviços médicos públicos ainda empregam maior atenção aos casos de infecção por Flavivirus Dengue e Zika.

Existem alguns métodos de diagnóstico disponíveis para a detecção da infecção por MAYV, porém, como revisado adiante, todos possuem limitações importantes, como alto valor de ruído (background), complexidade excessiva por utilizarem vírus em pelo menos uma das etapas de realização, inespecificidade dos resultados, dificuldade na coleta de amostras devido ao curto período de viremia e semelhança de sintomas com outras arboviroses. Estas, isoladas ou em associação, podem ser causas da falta de dados epidemiológicos da doença, gerando, como consequência, dificuldade na compreensão dos fatores de risco (ABAD-FRANCH et al., 2012). Por essa razão, é importante o desenvolvimento de um método diagnóstico para a detecção de anticorpos no soro contra a principal proteína imunogênica do vírus Mayaro, a glicoproteína E2. 
A obtenção de um sistema produtor de antígenos de MAYV por si só é um importante objetivo alcançado neste trabalho, pois a demanda pela expressão recombinante dessas proteínas já é colocada há alguns anos em estudos anteriores (OLIVEIRA, 2008), por ser um dos pontos limitantes ao desenvolvimento de métodos modernos de diagnóstico da doença. Em síntese, este trabalho contribui para o desenvolvimento de novos métodos de diagnóstico da infecção pelo vírus Mayaro através do desenvolvimento de uma ferramenta biotecnológica que poderá ser utilizada em um teste de imunofluorescência para identificação de infecção por Alphavirus. Este trabalho também é pioneiro na expressão recombinante da proteína E2 do MAYV e na utilização de células S2 de Drosophila melanogaster como suporte para o desenvolvimento de um método de imunofluorescência. 


\section{REVISÃO BIBLIOGRÁFICA}

\subsection{Virus Mayaro}

MAYV é um arbovírus da família Togaviridae, gênero Alphavirus, muito próximo antigenicamente ao vírus Semliki Forest Virus (SFV), fazendo parte do mesmo complexo deste juntamente com os vírus Chikungunya, O'nyong-nyong, UNA e Ross River (MUÑOZ; NAVARRO, 2012; VASCONCELOS et al., 1998). As infecções por vírus pertencentes a este gênero estão associadas ao desenvolvimento de doença reumática ou doença encefalítica. Entre os responsáveis pelo desenvolvimento de artrites, além do vírus Mayaro, estão os vírus Chikungunya (CHIKV), Ross River (RRV), Barmah Forest (BFV), O'nyong-nyong e o grupo de vírus Sindbis (SUHRBIER; LA LINN, 2004; TOIVANEN, 2008).

Foi isolado de trabalhadores rurais pela primeira vez no ano de $1954 \mathrm{em}$ Trindade e Tobago e desde então tem sido relatado em diversos países da América do Sul e Central (FERREIRA et al., 2000; MOTA et al., 2015). Sua circulação já é comprovada há algumas décadas quando foi considerado a causa do surto de doença febril ocorrido no Estado do Pará no ano de 1955 (CAUSEY; MAROJA, 1957; CAUSEY; THEILER, 1958). Foi recentemente identificado nos soros de pacientes do Estado do Mato Grosso, Brasil, que haviam sido diagnosticados previamente para Dengue. O perfil destes pacientes era de ambos os sexos, com idade entre 14 e 62 anos, que, na grande maioria, apresentavam febre, náusea, vômito, mialgia, artralgia e dores oculares e abdominais. Sintomas parecidos aos causados por DENV também podem ser observados em indivíduos infectados com o vírus Zika, recentemente associado à Síndrome de Guillain-Barré caracterizada por tetraparestesia predominantemente nos membros inferiores, parestesia das extremidades, mialgia difusa, paralisia facial assimétrica e bilateral e abolição dos reflexos tendinosos profundos (MARCONDES; XIMENES, 2015).

A transmissão do vírus Mayaro era sabidamente limitada às regiões de áreas florestais, tendo como vetor Haemagogus janthinomys, da família Culicidae (MUÑOZ; NAVARRO, 2012). No entanto, LONG et al. já demonstravam, em 2011, que a espécie Aedes aegypti poderia ser um candidato potencial para o estabelecimento de um ciclo urbano de transmissão devido à sua capacidade em transmitir o vírus para camundongos. Vale ressaltar que a lista de insetos em que o MAYV já foi encontrado conta com vários representantes da família Culicidae, abrindo a possibilidade de transmissão viral por mais de um vetor e demonstrando 
sua capacidade de adaptação entre diferentes gêneros, tais como Culex, Aedes e Sabetes, o que acaba por ser mais um fator contribuinte à dispersão urbana da doença (MUÑOZ \& NAVARRO, 2012). Casos de identificação de MAYV no Pantanal, Mato Grosso do Sul, indicaram que o vírus circulava ao nível do chão, não se restringindo mais às copas das árvores, aumentando o risco de infectar humanos (PAUVOLID-CORRÊA et al., 2015). Recentemente, a urbanização do vírus Mayaro foi comprovada no Estado de Mato Grosso por estudos realizados por SERRA et al., 2016 e ZUCHI et al., 2014.

$\mathrm{O}$ vetor em comum de todos esses agentes etiológicos de arboviroses ressalta a necessidade de uma reavaliação do papel vetorial dos mosquitos, assim como o diagnóstico e controle das doenças (MARCONDES; XIMENES, 2015). Para um melhor entendimento dos mecanismos de expansão das arboviroses que levam à urbanização das mesmas, é importante realizar o estudo da epidemiologia molecular por meio da caracterização genética e filogenética dos isolados virais, o que somente é possível após o correto diagnóstico. Portanto, um melhor conhecimento eco-epidemiológico é indispensável para entender como as arboviroses se mantêm na natureza (ACADEMIA BRASILEIRA DE CIÊNCIAS, 2010).

Uma das possíveis explicações para o aumento do número de casos de infecção por Alphavirus é a degradação do meio ambiente e o crescimento populacional, pois em aglomerações urbanas as chances de contágio são maiores, além do fato de que indivíduos em período de incubação facilitam a disseminação de agentes etiológicos de doenças virais por longas distâncias em vôos internacionais. A própria migração para áreas urbanas e o crescimento descontrolado das cidades, que leva à infraestrutura e água encanada inadequadas, tornam difíceis a redução de populações de mosquitos Aedes aegypti a níveis seguros, contribuindo, assim, para uma maior circulação de patógenos. Na América Latina, Aedes Aegypti e Aedes albopictus são amplamente distribuídos e numerosos na maioria das pequenas e grandes cidades (FIGUEIREDO; FIGUEIREDO, 2014; MARCONDES; XIMENES, 2015). Na região Nordeste do Brasil mais de 75\% dos criadouros são devido ao armazenamento precário de água, enquanto no Sudeste os mesmos ocorrem em recintos domiciliares (MARCONDES; XIMENES, 2015). Com a grande dispersão desses vetores da espécie Aedes, a ocorrência de infecções concomitantes dos vírus Dengue, Chikungunya e Zika (cepa Asiática) pode tornar-se cada vez mais frequente, conforme já foi observado entre os anos de 2011 e 2014 na região do Pacífico (MARCONDES; XIMENES, 2015), e a escalada dos casos de infecção por Mayaro torna o cenário de transmissão de arboviroses ainda mais preocupante. 


\subsection{Genoma e replicação do vírus Mayaro}

O genoma do vírus Mayaro contém 11,5 Kb de nucleotídeos e sua organização é típica dos Alphavirus (LAVERGNE et al., 2006). É um vírus pequeno, icosaédrico e envelopado, medindo entre 65-70nm de diâmetro. Devido à falta de estudos sobre MAYV, a maior parte do conhecimento da sua biologia molecular é baseada em estudos que têm sido conduzidos com os vírus Sinbdis ou CHIKV, os quais são intimamente relacionados (MOTA et al., 2015).

A fita simples de RNA positivo dos Alphavirus funciona como uma molécula de RNA mensageiro e como molde para a síntese de RNA negativo, a partir do qual uma RNA polimerase viral RNA-dependente transcreve o genoma viral. Duas ORFs (Open Reading Frames) são descritas no genoma do MAYV. A primeira ORF engloba dois terços do RNA genômico a 5', o qual pode ser lido diretamente como um RNA mensageiro que codifica uma poliproteína de 2453 aminoácidos da qual cada proteína não-estrutural (nsP1, nsP2, nsP3 e nsP4) é formada após a clivagem proteolítica promovida pela nsP2. As proteínas nãoestruturais são necessárias à transcrição e replicação do RNA viral. As proteínas estruturais são sintetizadas sequencialmente, como uma poliproteína de $138 \mathrm{kDa}$, a partir da segunda ORF, a 3', seguindo a ordem: proteína do nucleocapsídeo (C), p62 (glicoproteínas E3 e E2), 6k e E1, sendo codificadas por uma fita de RNA positiva subgenômica chamada RNA 26S. Este RNA é transcrito a partir de uma fita de RNA 26S intermediário negativo e é idêntico a um terço da extremidade 3’ do RNA genômico. E1 e E2 são glicoproteínas de envelope e E3 e proteína 6K dois pequenos peptídeos (CHENG et al., 1995; FLORES, 2007; MOTA et al., 2015; STRAUSS; STRAUSS, 1994). As glicoproteínas E1, E2 e E3 têm tamanhos de, aproximadamente, $52 \mathrm{kDa}, 49 \mathrm{kDa}$ e $10 \mathrm{kDa}$, respectivamente, e a proteína do nucleocapsídeo 30 kDa (CHENG et al., 1995; STRAUSS; STRAUSS, 1994). O genoma dos Alphavirus está representado na figura 1 .

A localização genética das poliproteínas estruturais e não-estruturais foi estimada através da comparação das sequências de aminoácidos com os sítios conhecidos de clivagem de outros Alphavirus. A composição de bases é de 27,4\% de Adenina, 25,7\% de Citosina, 25,7\% de Guanina e 21,2\% de Timina (Uracila) (LAVERGNE; et al., 2006). Existem poucos estudos específicos sobre as proteínas do vírus Mayaro. A maioria das informações é relacionada à Alphavirus (MOTA et al., 2015) 
Figura 1 - Esquema do genoma dos Alphavirus.

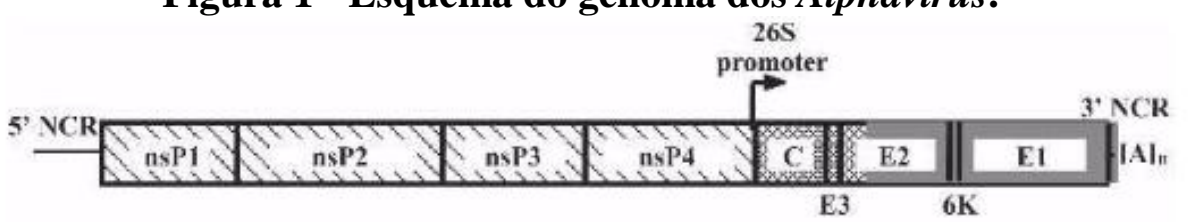

Fonte: Powers et al. (2006).

O ciclo de replicação do MAYV é igual a dos demais Alphavirus. De maneira geral, a presença de receptores específicos na membrana da célula hospederia permite a entrada do vírus Mayaro pelo processo de endocitose. A glicoproteína E2 é responsável pelo contato das partículas virais com tais receptores, sendo os anticorpos anti-E2, por esta razão, capazes de neutralizar a infecção viral (MUÑOZ; NAVARRO, 2012). Após o contato do hospedeiro vertebrado com o vírus, a partícula viral é introduzida em uma vesícula endocítica, de forma que seu envelope se fusiona à membrana do endossoma mediante ação da glicoproteína E1 e dependente da acidificação da vesícula. As alterações de $\mathrm{pH}$ e da concentração iônica intracelular permitem a liberação da nucleocápside, com consequente inserção do genoma viral no citoplasma e síntese da ORF das proteínas não-estruturais pelos ribossomos, produzindo uma poliproteína que sofre clivagem para gerar nsP1, nsP2, nsP3 e nsP4 (FLORES, 2007). A proteína nsP1 é relacionada ao início específico e/ou manutenção dos intermediários replicativos. Apresenta atividades de transferase, importante para o capping e metilação de RNA viral genômico e subgenômico recém-sintetizado. Durante a replicação viral, nsP1 contribui para a ancoragem dos complexos de replicação viral às membranas citoplasmáticas.

Nos vírus Semliki Forest e Chikungunya, a proteína nsP2 exibe múltiplas funções enzimáticas, incluindo helicase, nucleosídeo trifosfatase (NTPase) e atividades de trifosfatase RNA-dependente. A região C-terminal de nsP2 codifica uma protease viral importante para o processamento da poliproteína não-estrutural. Além disso, nsP2 apresenta diversos sinais de localização nuclear e, aproximadamente, $50 \%$ do conteúdo intracelular de nsP2 é encontrado dentro do núcleo em qualquer momento do processo replicativo. No entanto, o papel que esta proteína desenvolve dentro do núcleo permanece desconhecido, uma vez que a replicação do RNA e o processamento da poliproteína ocorrem no citoplasma. A proteína nsP3 é a menos conhecida das proteínas não-estruturais, mas também atua na replicação do RNA viral. Acredita-se que a nsP4 participa de interações com outras nsPs ou proteínas do hospedeiro. Seu domínio C-terminal possui função de RNA polimerase RNA-dependente e o N-terminal a atividade de adenilil-transferase (MOTA et al., 2015). 
Durante o processamento co-traducional da poliproteína precursora das proteínas estruturais, a proteína de capsídeo é clivada por atividade autoproteolítica e permanece no citoplasma, enquanto que os ribossomos associados à membrana plasmática do retículo endoplasmático rugoso (RER) sintetizam as glicoproteínas p62, E1 e 6K. Esta última atua como sequência sinal para o processamento downstream da proteína E1 (FLORES, 2007; MOTA et al., 2015). Um trecho de resíduo apolar presente na região N-terminal da proteína p62, correspondente à sequência da proteína E3, funciona como um peptídeo sinal na translocação desta para o lúmen do retículo endoplasmático, facilitada pelo complexo formado por E1 e p62, o que torna este transporte eficiente. No Aparelho de Golgi p62 é clivada, dando origem às glicoproteínas E3 e E2 (FLORES, 2007; LOBIGS; HONGXING; GAROFF, 1990). Durante o transporte pelo retículo endoplasmático e pelas cisternas do Aparelho de Golgi ocorrem as modificações pós-traducionais requeridas e o processamento proteolítico final.

\section{Figura 2 - $\mathrm{O}$ ciclo replicativo dos Alphavirus.}

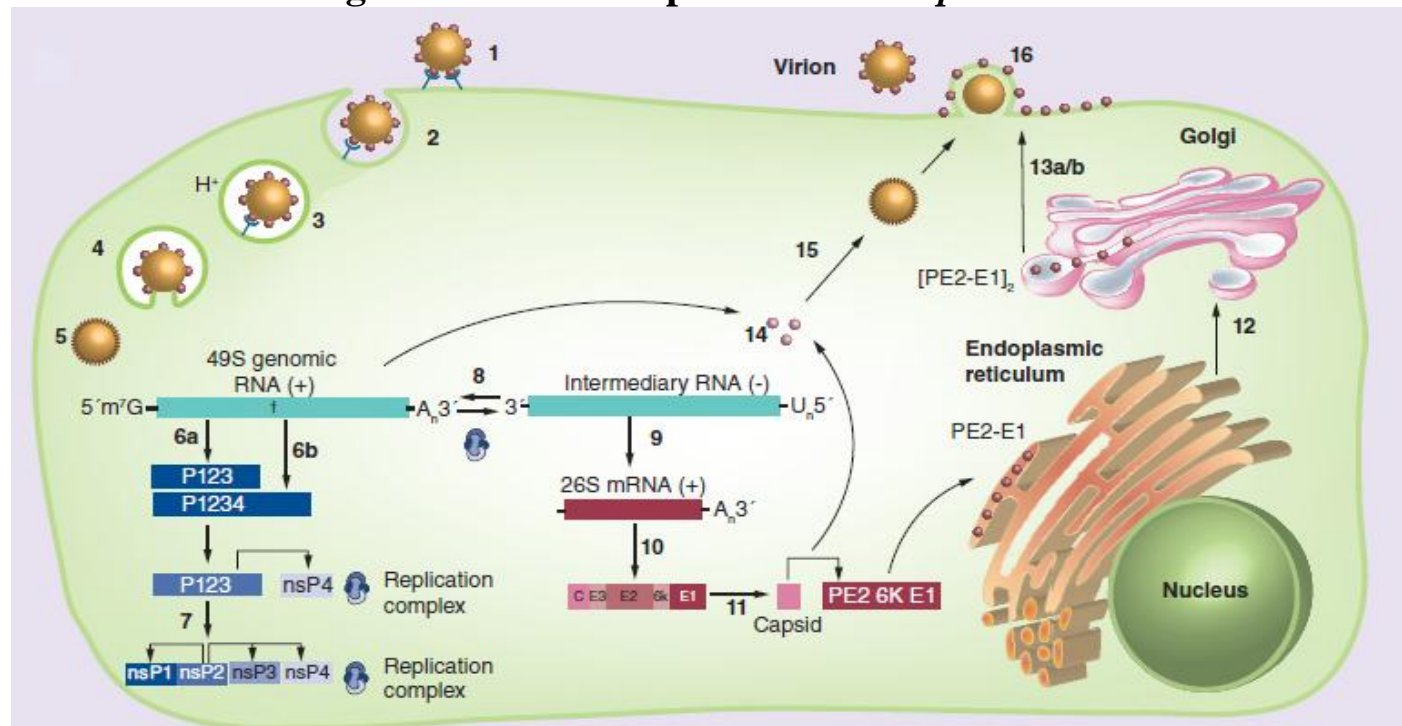

(1) Ligação ao receptor; (2) Endocitose mediada por receptor; (3) Acidificação do vacúolo; (4) Fusão com a membrana; (5) Separação do core; (6a) Tradução das proteínas não-estruturais; (6b) Tradução alternativa da poliproteína não-estrutural; (7) Formação do complexo de replicação; (8) Transcrição reversa para formação do RNA negativo e, a partir deste, de novas cópias do RNA genômico; (9) Transcrição do RNA subgenômico 26S; (10) Tradução das proteínas estruturais; (11) Proteólise mediada pela proteína de capsídeo e envio das demais proteínas estruturais ao lúmem do RER; (12) Processamento e maturação de glicoproteínas; (13a) Transporte das glicoproteínas processadas à membrana plasmática; (13b) Ativação proteína E2 mediada por Furina; (14) Empacotamento RNA genômico; (15) Montagem do nucleocapsídeo; (16) Brotamento das partículas virais. Fonte: Mota et al. (2015) 
As cópias de RNA positivo genômico produzidas no interior da célula hospedeira funcionam como base para outros ciclos de transcrição e tradução, sendo também direcionadas ao processo de encapsidação (FLORES, 2007).

\subsection{Transmissão e epidemiologia do vírus Mayaro}

O MAYV foi pela primeira vez isolado de amostras de sangue de cinco trabalhadores rurais febris em Trindade e Tobago no ano de 1954. Acredita-se que se mantém na América do Sul tropical em ciclos silvestres e rurais, envolvendo, primeiramente, mosquitos Haemagogus janthinomys como vetores e primatas não-humanos e pássaros como hospedeiros primários e secundários, respectivamente, sendo denominados hospedeiros amplificadores. Infecções humanas são geralmente esporádicas e acidentais devido à exposição ocupacional ou ao aumento da densidade dos mosquitos. Casos esporádicos, surtos e pequenas epidemias têm sido relatados em diversos países dentro de regiões tropicais da América do Sul e Central. Casos clínicos de Febre Mayaro e isolamento de MAYV têm sido relatados no Peru, Suriname, Guiana Francesa, Guiana, Venezuela, Colômbia, Equador, Panamá e Bolívia. Além disso, investigações sorológicas têm sugerido a presença do vírus na Costa Rica, Guatemala e México. No Brasil, MAYV tem sido encontrado principalmente na região Norte do país, incluindo os Estados do Pará e Amazonas. Diversos casos também têm sido relatados em viajantes que visitaram a Bacia Amazônica, ressaltando uma preocupação quanto à sua propagação para outros continentes. Além dessas regiões, a presença do vírus Mayaro é relatada em diversos Estados do Nordeste e Centro-Oeste, incluindo os Estados de Goiás, Mato Grosso e Mato Grosso do Sul (MOTA et al., 2015; SERRA et al., 2016; ZUCHI et al., 2014). A distribuição do vírus Mayaro nas Américas está representada na figura 3. 
Figura 3 - Distribuição de MAYV nas Américas do Sul e Central e Caribe.

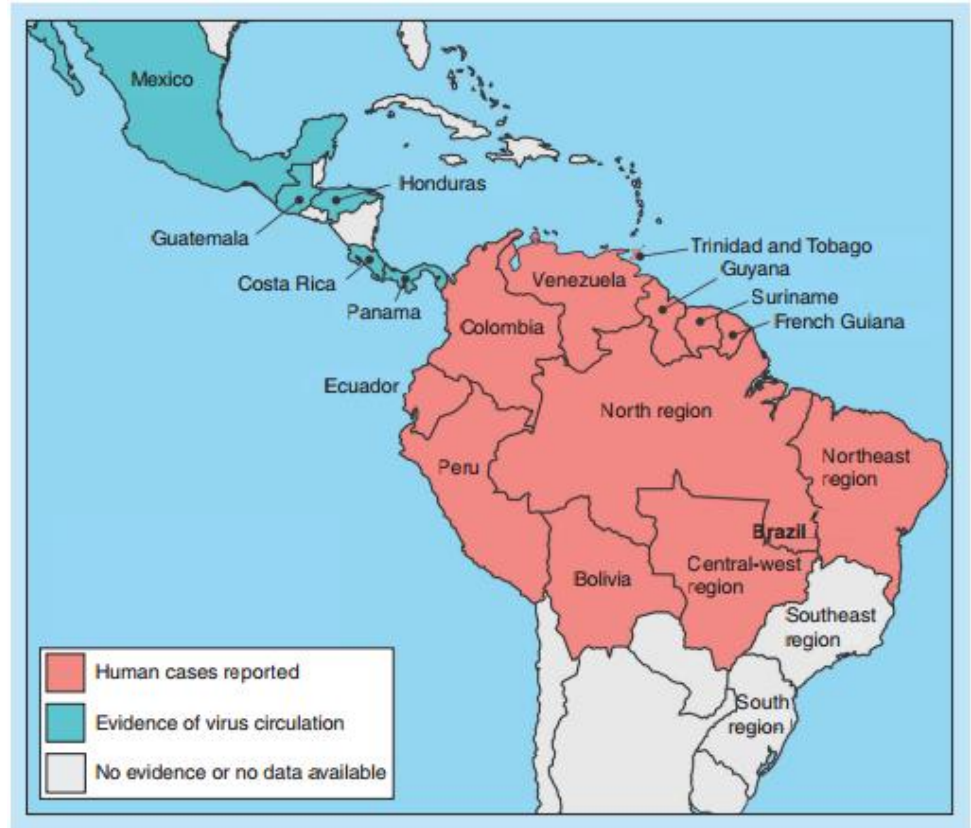

Fonte: Mota et al. (2015)

Pela grande capacidade de vôo do Haemagogus janthinomys, que pode chegar a 11 $\mathrm{km}$, consegue expandir sua área de atividade em busca de alimento, contribuindo para a ocorrência do ciclo rural, no qual se encontram humanos e animais domésticos (MUÑOZ; NAVARRO, 2012; SERRA et al., 2016). Os possíveis ciclos de transmissão do vírus Mayaro estão representados na figura 4.

Figura 4 - Ciclos enzoótico, rural e urbano do vírus Mayaro, baseando-se nos possíveis vetores e hospedeiros vertebrados.

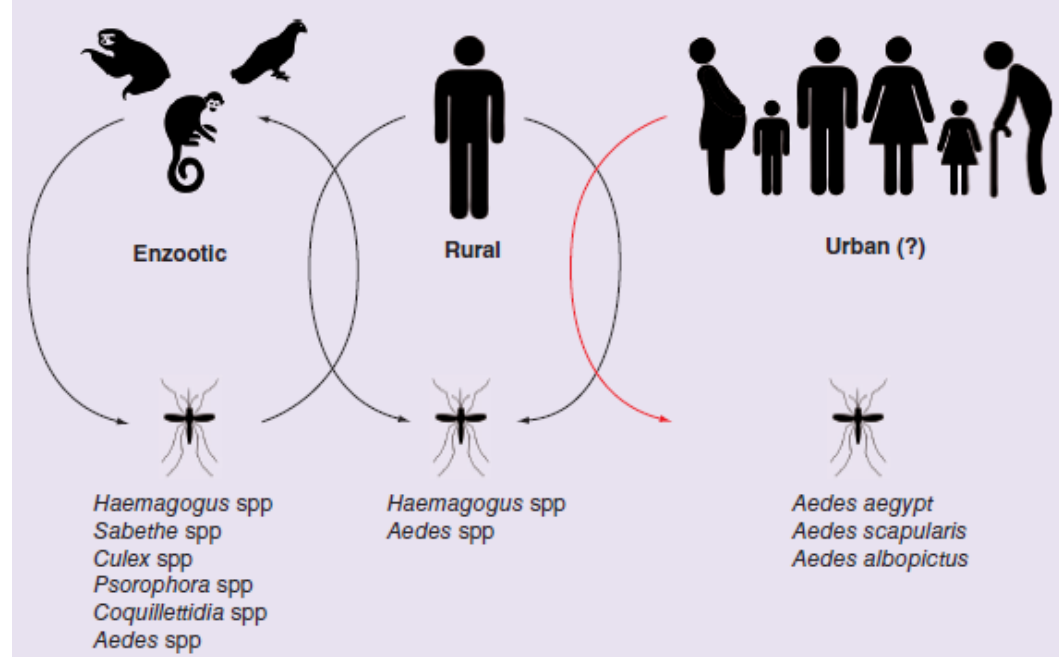

Fonte: Mota et al. (2015). 
No que se refere à possibilidade de ocorrência de urbanização da doença, Long et al. 2011 já demonstraram a eficiência do gênero Aedes aegypti em transmitir o vírus Mayaro, o que torna este um fator epidemiológico importante para a instalação de uma epidemia na área urbana e não mais uma barreira para este ciclo. MAYV é transmitido a hospedeiros vertebrados pelo contato com a saliva de artrópodes infectados que apresentam hábito hematófago, tais como mosquitos, moscas mordedoras e carrapatos, sendo que $80 \%$ daqueles capazes de atuar como vetores da doença pertencem à família Culicidae. Entre os artrópodes pode ocorrer transmissão vertical, envolvendo a passagem de vírus de um vetor fêmea infectado para toda a prole, ou horizontal, em que um macho verticalmente infectado transmite o vírus para a fêmea (MUÑOZ; NAVARRO, 2012; WEAVER, REISEN; 2010). Para ocorrer a infecção de artrópodes, a um nível suficiente para inseri-los no ciclo de transmissão, é necessária uma alta carga viral em hospedeiros vertebrados (MUÑOZ; NAVARRO, 2012). Este ocorre através da infecção do trato alimentar do vetor, seguida da disseminação e replicação do vírus nas glândulas salivares, com consequente passagem ao hospedeiro através de saliva infecciosa durante o processo de hematofagia (WEAVER, REISEN; 2010).

Um ciclo urbano de transmissão tem sido proposto para o vírus Mayaro em Manaus e Cuiabá. Neste estudo, o isolamento viral foi obtido de dois pools de Cx. quinquefasciatus e Ae. aegypti, os quais foram positivos apenas para MAYV. O isolamento de MAYV em espécies de Culicidae, como Aedes, Culex, Psorophora, Sabethes e Haemagogus spp tem sido relatado. Sequências de nucleotídeos de MAYV obtidas de CX. Quinquefasciatus mostraram 98-100\% de identidade com sequências do vírus obtidas de humanos em Cuiabá e na cidade de Várzea Grande, no Estado de Mato Grosso (MT). Sequências adquiridas de Aedes aegypti mostraram 99-100\% de identidade com sequências virais obtidas de humanos em Cuiabá durante o ano de 2012, indicando que o mesmo agente foi identificado em humanos e em mosquitos em MT. Os pacientes positivos para Mayaro em Cuiabá em 2012 eram residentes de áreas urbanas e negaram viagem recente a regiões rurais ou silvestres (ZUCHI et al., 2014). Estes achados corroboram para a ocorrência de transmissão urbana em Cuiabá (SERRA et al., 2016).

A importância destas espécies como vetores de MAYV é baseada nos seus hábitos urbano e antropofílico e na sua ampla distribuição geográfica, favorecendo o contato com humanos e, consequentemente, a transmissão viral e a urbanização de MAYV. A alta densidade populacional de mosquitos pode explicar as co-infecções por DENV e CHIKV em 
pools de Aedes albopictus, conforme observado na África, e a positividade dupla para MAYV e DENV-4 em cinco pools de mosquitos em Cuiabá, aumentando a possibilidade de infecção humana dupla através da picada de um único mosquito (SERRA et al., 2016).

De acordo com o Ministério da Saúde, durante o período de dezembro de 2014 e janeiro de 2016, 343 casos humanos de Febre Mayaro foram notificados, estando estes distribuídos em onze Estados das regiões Norte, Nordeste e Centro-Oeste do Brasil. O Estado de Goiás apresenta a maior frequência, sendo 183 (53,3\%) dos casos suspeitos. Na sequência, estão os Estados do Pará, com 68 suspeitas da doença (19,8\%) e Tocantins, 25 casos (7,2\%). Entre os casos registrados, 70 tiveram as suspeitas confirmadas, o equivalente a 20,4\%, 29 apresentaram-se negativos $(8,4 \%)$ e 244 (71,3\%) ainda continuam em investigação. Com base em informações obtidas durante a investigação preliminar, todos os casos confirmados tratavam-se de indivíduos residentes de áreas rurais ou que estiveram em regiões rurais, silvestres ou de mata, por motivos de trabalho ou lazer, durante um período inferior a 15 dias, antes do aparecimento dos sintomas. A tabela 1 mostra a frequência de casos suspeitos e confirmados pela Febre Mayaro (PORTAL DA SAÚDE-SUS, 2016).

Tabela 1 - Estados brasileiros com casos suspeitos notificados de Febre Mayaro, janeiro de 2016.

\begin{tabular}{|c|c|c|c|c|c|c|c|c|}
\hline & \multicolumn{8}{|c|}{ Casos notificados } \\
\hline & \multicolumn{2}{|c|}{ Confirmados } & \multicolumn{2}{|c|}{ Em investigação } & \multicolumn{2}{|c|}{ Descartados } & \multicolumn{2}{|c|}{ Total } \\
\hline & 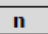 & $\%$ & n & $\%$ & $\mathbf{n}$ & $\%$ & $\mathbf{n}$ & $\%$ \\
\hline Goiás & 60 & 85,7 & 133 & 54,5 & 10 & 34,4 & 183 & 53,3 \\
\hline Pará & 1 & 1,4 & 56 & 22,9 & 11 & 37,9 & 68 & 19,8 \\
\hline Tocantins & 9 & 12,8 & 16 & 6,5 & 0 & 0,0 & 25 & 7,2 \\
\hline Roraima & 0 & 0,0 & 23 & 9,4 & 5 & 17,2 & 28 & 8,1 \\
\hline Mato Grosso & 0 & 0,0 & 20 & 8,1 & 0 & 0,0 & 20 & 5,8 \\
\hline Amazonas & 0 & 0,0 & 6 & 2,4 & 2 & 6,8 & 8 & 2,3 \\
\hline Amapá & 0 & 0,0 & 6 & 0,4 & 1 & 3,4 & 7 & 2,0 \\
\hline Bahia & 0 & 0,0 & 1 & 0,4 & 0 & 0,0 & 1 & 0,3 \\
\hline Minas Gerais & 0 & 0,0 & 1 & 0,4 & 0 & 0,0 & 1 & 0,3 \\
\hline Mato Grosso do Sul & 0 & 0,0 & 1 & 0,4 & 0 & 0,0 & 1 & 0,3 \\
\hline Distrito Federal & 0 & 0,0 & 1 & 0,4 & 0 & 0,0 & 1 & 0,3 \\
\hline Total & 70 & 100,0 & 244 & 100,0 & 29 & 100,0 & 343 & 100,0 \\
\hline
\end{tabular}

Fonte: Portal da Saúde - SUS (2016).

Os sinais e sintomas mais encontrados entre os casos registrados de Febre Mayaro foram febre e artralgia (100\%), edema articular (92,9\%), cefaleia e mialgia (89,3\%), exantema $(60,7 \%)$, dor ocular $(50 \%)$ e prostração $(46,4 \%)$. Entre os de menor frequência estavam erupções cutâneas e icterícia $(10,7 \%)$, congestão ocular e fotofobia $(3,6 \%)$. Estes dados foram obtidos do Ministério da Saúde brasileiro (Gráfico 1) (PORTAL DA SAÚDE-SUS, 2016). 
Gráfico 1 - Sinais e sintomas encontrados nos casos de doença febril por MAYV em Estados brasileiros durante junho de 2015.

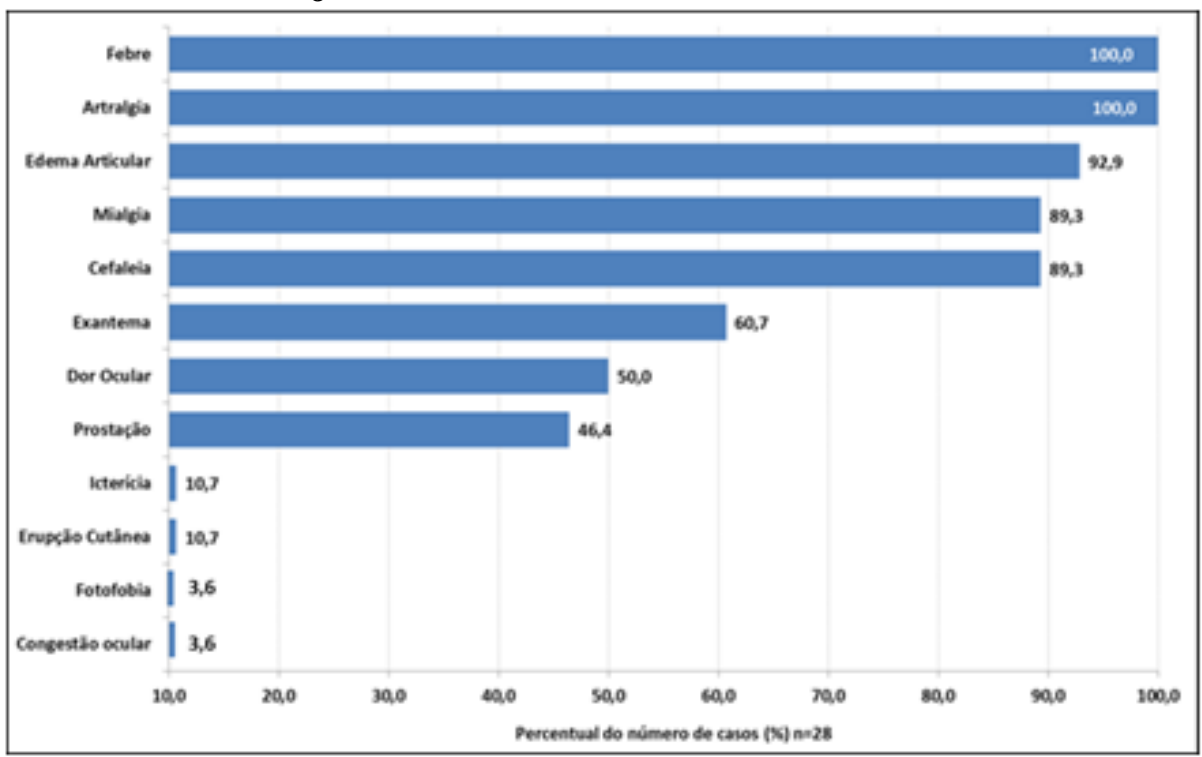

Fonte: Portal da Saúde - SUS (2016).

Análises filogenéticas realizadas a partir do sequenciamento de aproximadamente $2 \mathrm{~kb}$ dos genes das glicoproteínas E1 e E2 e da região 3' completa não codificante indicaram que existem dois genótipos do vírus Mayaro. Um é denominado "D”, encontrado em isolados de Trindade e Tobago, Peru, Guiana Francesa, Suriname, Brasil e Bolívia. Tais isolados são altamente conservados, com uma divergência de nucleotídeo de menos de $6 \%$. O segundo genótipo, denominado "L", foi isolado apenas no Brasil, apresentando diferentes isolados altamente conservados, com menos de $4 \%$ de divergência de nucleotídeos. A distinção entre os genótipos varia de $15 \%$ a $19 \%$, apenas (POWERS et al., 2006).

O conhecimento da diversidade de espécies de Culicidae e sua frequência de infecção por arboviroses em regiões onde epidemias são frequentes se fazem importantes para prever quais arbovírus devem circular em humanos ou se disseminar após sua introdução (SERRA et al., 2016). Estudos de vigilância envolvendo entomologia e virologia são importantes ferramentas para monitorar a fauna de mosquitos e determinar as estratégias de intervenção para controlar e prevenir epidemias por estes vírus. Medidas de controle geralmente são direcionadas às populações de Aedes em áreas urbanas. Outras espécies de Culicidae, também importantes para a transmissão de arbovírus, acabam sendo negligenciadas (SERRA et al., 2016). 


\subsection{Patogênese da doença febril por Mayaro e demais Alphavirus}

Após a inoculação subcutânea através da picada do mosquito infectado, os Alphavirus parecem ser disseminados no hospedeiro pela rota dos gânglios linfáticos e microvasculatura. A leucopenia na fase aguda da doença é uma alteração hematológica muito comum em infecção por Alphavirus, sugerindo uma replicação primária do vírus nos leucócitos. Fígado e baço também são considerados sítios de replicação viral primária e contribuem para a disseminação do agente. Após esta disseminação, o vírus alcança os ossos, músculos e tecidos articulares, gerando a fase aguda da doença, a qual é fortemente associada com um processo inflamatório local. A idade do hospedeiro, o estado do sistema imunológico, a virulência da cepa do agente etiológico e a persistência viral são fatores determinantes para a patogênese da infecção por Alphavirus em animais (ASSUNÇÃO-MIRANDA et al., 2013).

A doença febril causada pelo vírus Mayaro apresenta 2 fases. A aguda constitui uma viremia transiente curta. O período de incubação ocorre de 7 a 12 dias, mas períodos menores foram observados. Após o tempo de incubação, inicia-se de forma súbita febre, entre $39{ }^{\circ} \mathrm{C}$ e $40,2{ }^{\circ} \mathrm{C}$, acompanhada por dor de cabeça, artralgia, mialgia, edemas articulares, calafrios, dor retro-orbital, mal-estar, erupção cutânea, vômito e diarreia. Em alguns casos, há a presença de náusea, tosse, dor de garganta, dor abdominal, congestão nasal, prurido, anorexia, inchaço dos gânglios linfáticos e sangramento nas gengivas. Aproximadamente 20\% dos casos apresentam inchaço das articulações pequenas, especialmente nos pulsos, dedos, tornozelos e dedos dos pés. A ocorrência de erupção cutânea é mais comum em crianças do que em adultos e, geralmente, aparece no quinto dia da doença e persiste por 3 a 4 dias. Os demais sintomas geralmente persistem por 2 a 5 dias. Depois da fase aguda inicia-se a fase covalescente. Esta pode ser acompanhada por artralgia e artrite, que pode perdurar por semanas ou meses. A artralgia começa com o início dos sintomas, podendo ser dolorosa e altamente incapacitante afetando mãos, pulsos, cotovelos, pés, joelhos e, em menor grau, os quadris e articulações axiais. Os membros se tornam fracos e muito sensíveis ao toque. Artrite é o achado clínico menos comum, porém pode persistir por meses após a doença (MOTA et al., 2015).

A severidade da doença e a persistência dos sintomas estão associados à extensão da replicação viral e à presença de mediadores inflamatórios no plasma dos pacientes e em tecidos específicos de modelos animais. Algumas citocinas secretadas durante a infecção por Alphavirus são as mesmas que aquelas associadas com a progressão da artrite reumatóide, no entanto a inflamação nesta é claramente associada ao processo autoimune, o qual não tem 
sido demonstrado de forma consistente para Alphavirus indutores de artrite. Infiltração celular inflamatória nas articulações, músculos e tecidos associados durante a infecção por Alphavirus tem sido relatada em alguns modelos de camundongo infectados pelos vírus Ross River e Chikungunya, sugerindo que o prejuízo muscular e articular é uma desordem inflamatória imunopatológica. Nas infecções por estes vírus, o infiltrado celular alcança o tecido sinovial, que apresenta uma forte hiperplasia. Monócitos, macrófagos, células NK e linfócitos TCD8+e TCD4+ são os principais componentes celulares do infiltrado inflamatório em modelos animais, indicando o envolvimento destes na patogênese da artrite induzida por Alphavirus. Artralgia crônica e artrite causam manifestações clínicas com restrição de movimentos e persistência de inchaço e dor até uma doença severa e incapacitante (ASSUNÇÃO-MIRANDA et al., 2013).

Figura 5 - Patogênese de Alphavirus indutor de artrite/miosite.

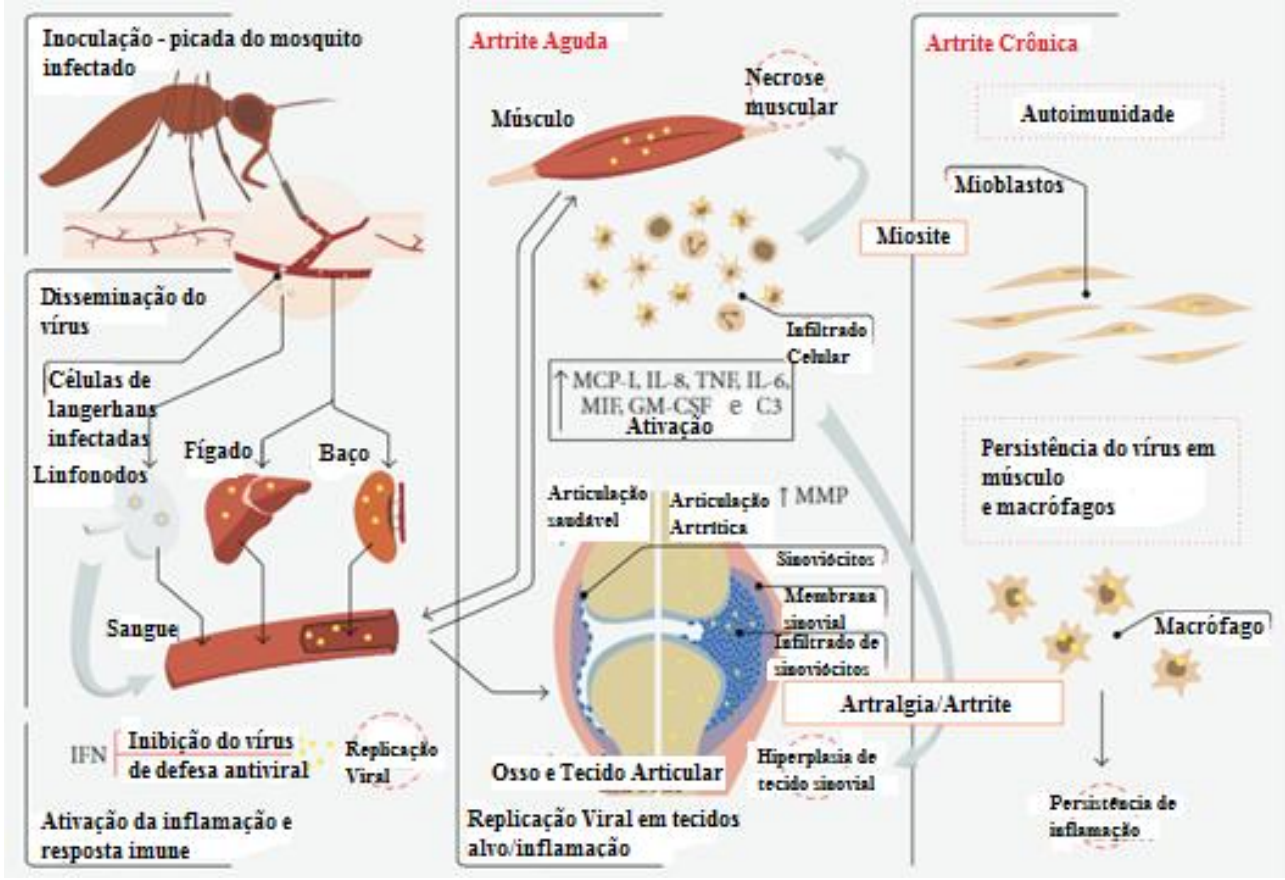

Fonte: Assunção-Miranda et al. (2013).

Quanto à resposta celular infamatória, após a inoculação através da picada de um mosquito infectado, o Alphavirus se dissemina no organismo hospedeiro por meio da corrente sanguínea. Fígado, baço, músculo e linfonodos são os sítios primários de replicação, permitindo a propagação eficiente do vírus. Células de Langerhans facilitam a entrega aos linfonodos. A resposta baseada em Interferon (IFN) é rapidamente ativada, porém os Alphavirus desenvolveram diversos mecanismos para inibir tal resposta antiviral. A fase aguda da doença envolve a replicação do vírus seguida por uma resposta inflamatória em 
tecidos alvo, os quais são caracterizados por uma extensa infiltração de linfócitos, células Natural Killer (NK), neutrófilos e macrófagos (o principal componente). O aumento dos níveis de diversas citocinas proinflamatórias e quimiocinas no sítio de infecção e no plasma está associado com miosite e artralgia/artrite. A secreção de metaloproteinases (MMP) no tecido articular pode contribuir para o prejuízo local. A persistência dos sintomas pode estar relacionada à persistência do vírus ou seus produtos nas células alvo, com consequente acúmulo de mediadores inflamatórios como IL-6 e GM-CSF (ASSUNÇÃO-MIRANDA et al., 2013).

\subsection{Métodos de diagnóstico disponíveis para a detecção da infecção por Mayaro}

Um dos aspectos mais importantes na proposição e validação de um método diagnóstico é sua precisão. Esta é obtida pela relação entre sua sensibilidade e especificidade: A sensibilidade é a capacidade de um exame detectar a doença quando ela está presente. Um teste sensível geralmente não deixará de detectar a doença. A especificidade, por outro lado, é a capacidade de um exame identificar corretamente a ausência de doença. Um teste específico raramente catalogará uma pessoa sadia como doente (AMARAL, 2007). De acordo com FRANCIS et al. (1988), o uso de proteínas recombinantes para fins de diagnóstico aumenta os fatores sensibilidade e especificidade, além de diminuir o tempo de produção e custos do ensaio de detecção de anticorpos a ser estabelecido. Da mesma forma, o diagnóstico da infecção por MAYV também seria facilitado pela disponibilidade de antígeno recombinante (OLIVEIRA, 2008).

A detecção de DENV e MAYV destaca a importância do diagnóstico diferencial em pacientes com suspeita de Febre Dengue. A apresentação clínica não-específica da Febre Mayaro é geralmente confundida com a doença causada pelo vírus Dengue, que é amplamente distribuído e ocorre frequentemente no Brasil. O diagnóstico laboratorial tem sido direcionado para a infecção por esse Flavivírus, o qual poderia prejudicar a identificação de outras arboviroses importantes eventualmente circulantes na população, incluindo aqueles nunca registrados antes no Brasil. Por este motivo, investigações moleculares seriam úteis para o rastreio da população e o diagnóstico diferencial de arbovírus (ZUCHI et al., 2014).

Geralmente, o diagnóstico da doença febril por Mayaro baseia-se apenas em achados clínicos, os quais podem confundir esta com outras arboviroses, como Dengue. O único método padrão ouro para diagnóstico de MAYV é o isolamento viral do sangue. No entanto, o 
curto período de viremia pode dificultar este processo. Na maioria das vezes, o isolamento é realizado em cultura de células de inseto (Aedes albopictus C6/36) e células de mamífero (VERO - African Green Monkey Kidney) ou em camundongos com inoculação intracerebral. O desenvolvimento de efeitos citopáticos requer no mínimo 3 dias. Sensíveis e de fácil execução, testes como PCR Convencional e PCR Quantitativa, utilizando primers genéricos para Alphavirus ou primers vírus-específicos, são boas escolhas para o diagnóstico mais confiável de infecções por MAYV. No entanto, outros métodos, como detecções sorológicas, também podem ser aplicados. Métodos sorológicos como Enzima Imunoensaios, imunofluorescência, inibição de hemaglutinação ou métodos de neutralização são úteis para detecção de anticorpos anti-Mayaro. Anticorpos do tipo IgM podem ser tipicamente detectados após 3 dias do aparecimento dos sintomas e persistir por mais de 3 meses, sendo substituído por $\operatorname{IgG}$, o qual pode permanecer por anos. Achados laboratoriais são despercebidos: leucopenia apresenta ocorrência comum; algumas vezes albuminúria suave e leve trombocitopenia são detectadas, assim como um leve aumento na taxa de sedimentação eritrocitária e nos níveis de alanina aminotransferase e moderada linfocitose (MOTA et al., 2015).

Diversas técnicas possibilitam a identificação e, portanto, o diagnóstico de infecções virais, entre elas estão PCR convencional e em tempo real (qPCR). A inovação tecnológica da técnica de PCR, a chamada PCR em Tempo Real, tem se mostrado ainda mais importante na área de diagnósticos clínicos e laboratórios de pesquisa devido à sua capacidade em fornecer resultados quantitativos, ao contrário da PCR convencional que somente gera dados qualitativos (VALONES, et al., 2009). No entanto, alguns fatores podem interferir na sensibilidade da técnica de PCR convencional e de Tempo Real, como a extração do RNA e condições inadequadas de armazenamento que podem levar ao prejuízo da integridade do RNA, além da possibilidade de erros na quantificação de produtos de amplificação inespecíficos como a formação de primers dimers (BRONZONI, et al., 2005; VALONES, et al., 2009). Além da técnica de PCR convencional e quantitativa, existem muitas outras disponíveis para o diagnóstico do vírus Mayaro, entre elas o isolamento viral, hemaglutinação $(\mathrm{IH})$, fixação do complemento (FC), soroneutralização (SN), ELISA-MAC (ELISA para captura de anticorpos IgM), EIA-ICC (suporte antigênico baseado em células de dípteros C6/36 infectadas com o vírus Mayaro) também para detecção de anticorpos IgM durante fase aguda da doença, ENAGYS-MAY e Imunocromatografia, as quais apresentam vantagens e desvantagens particulares, revisadas abaixo. 
O método de isolamento viral descrito na literatura para o diagnóstico do vírus Mayaro apresenta limitações na recuperação do vírus do soro de hospedeiros humanos durante surtos. A baixa titulação viral, a própria viremia transiente e degradação do RNA viral podem servir como possíveis explicações para a dificuldade em isolar o vírus (ZUCH et al., 2014). A Inibição da Hemaglutinação (IH), usada na rotina de diagnóstico de MAYV, apresenta-se de fácil execução, sensível e de baixo custo, porém necessita de duas coletas de amostras do paciente infectado para o correto diagnóstico e também, de frequente disponibilidade de hemácias de ganso que compõem o teste. Outros testes, como fixação do complemento (FC) e soroneutralização (SN) têm como vantagem a especificidade sorológica. No entanto, são de difícil execução, necessitando de profissionais capacitados para realizá-las (OLIVEIRA, 2008). O método de ELISA apesar de apresentar alta sensibilidade, pode não detectar a doença em casos de infecção secundária, em que os títulos de IgM podem estar em níveis mais baixos (OLIVEIRA, 2008). O teste proposto de ELISA-MAC, mesmo sendo sensível para captura de anticorpos IgM, pode apresentar reação cruzada com outros Alphavirus do complexo Semliki Forest (entre os quais está o Chikungunya) e falso positivo quando da presença de altos níveis de fator reumatóide no soro de pacientes (FIGUEIREDO et al., 1989). O teste ENAGYS-MAY (OLIVEIRA, 2008) utiliza amostras de sangue impregnadas em papel de filtro, sendo capaz de detectar anticorpos anti-Mayaro, mas, assim como IH, são necessárias duas amostras de sangue do paciente, com intervalo de 15 dias para o diagnóstico correto. Figueiredo et al., 1989, propuseram o teste EIA-ICC para detecção de IgM e IgG contra o vírus Mayaro com boa sensibilidade e especificidade, permitindo o diagnóstico de infecção recente, porém o suporte antigênico consiste em cultura de células C6/36 infectadas, o que depende do manuseio do vírus Mayaro selvagem, sendo preocupante quanto à biossegurança. Já a técnica de imunocromatografia tem sido amplamente estudada como um teste rápido, eficaz e sensível para o diagnóstico de infecção pelo vírus Dengue. No entanto, Pal et al., 2014 demonstraram que os kits de ELISA apresentam ainda sensibilidade superior e, por seu melhor desempenho, é a escolha diagnóstica recomendada pela Organização Mundial de Saúde (OMS). Isso também pode ser extrapolado para o vírus Mayaro. Além disso, o Ministério da Saúde, em seu roteiro para capacitação de profissionais médicos no diagnóstico e tratamento da Dengue (2007), ressalta a necessidade de confirmação do diagnóstico pela técnica de ELISA após a realização de ensaio imunocromatográfico (MINISTÉRIO DA SAÚDE, 2007). 
A tabela 2 abaixo apresenta um resumo dos métodos de detecção utilizados para o diagnóstico da infecção por MAYV nos países onde a circulação do vírus já foi registrada.

TABELA 2 - Dados epidemiológicos disponíveis da circulação do vírus Mayaro.

\begin{tabular}{|l|l|l|}
\hline País/Região & Hospedeiro & Método de Detecção \\
\hline $\begin{array}{l}\text { Bolivia } \\
\text { Oeste }\end{array}$ & Humanos & $\begin{array}{l}\text { Sorológico; molecular; } \\
\text { isolamento }\end{array}$ \\
\hline Brasil, região Norte & $\begin{array}{l}\text { Humanos; primatas não-humanos; } \\
\text { outrosmamíferos; lagartos; pássaros; } \\
\text { mosquitos }\end{array}$ & $\begin{array}{l}\text { Sorológico; molecular } \\
\text { isolamento molecular; }\end{array}$ \\
\hline $\begin{array}{l}\text { Brasil, região } \\
\text { Nordeste }\end{array}$ & Humanos & Sorológico \\
\hline Colômbia & Humanos; mosquitos & Sorológico; isolamento \\
\hline Costa Rica & Humanos & Sorológico \\
\hline Equador & Humanos & Sorológico \\
\hline Guiana Francesa & $\begin{array}{l}\text { Humanos; primatas não-humanos; } \\
\text { outrosmamíferos }\end{array}$ & $\begin{array}{l}\text { Sorológico; molecular; } \\
\text { isolamento }\end{array}$ \\
\hline Guatemala & Humanos; primatas não-humanos & Sorológico \\
\hline Guiana & Humanos & Sorológico \\
\hline Honduras & Primatasnão-humanos & Sorológico \\
\hline México & Humanos & Sorológico \\
\hline Panamá & Primatas não-humanos & Sorológico; isolamento \\
\hline Peru & Humanos & $\begin{array}{l}\text { Sorológico; molecular; } \\
\text { isolamento }\end{array}$ \\
\hline Suriname & Humanos & Sorológico; isolamento \\
\hline Trindade e Tobago & $\begin{array}{l}\text { Humanos; primatas não-humanos; } \\
\text { mosquitos }\end{array}$ & Sorológico; isolamento \\
\hline Venezuela & Humanos & Sorológico \\
\hline
\end{tabular}

Detecção sorológica: detecção de anticorpos em soro de hospedeiro; detecção molecular: RT-PCR; isolamento: isolamento viral em cultura de células. Fonte: Mota et al. (2015).

A técnica de Imunofluorescência Indireta (IFI) mostra-se uma boa opção (OLIVEIRA, 2008), sendo IFI frequentemente utilizada em biologia celular e molecular para demonstrar as localizações e funções de proteínas alvo, que podem ser intracelulares ou de membrana (DUAN, et al., 2012), além de ser capaz de detectar anticorpos contra as proteínas virais no soro de animais ou pacientes infectados. Essa metodologia já foi descrita como uma boa forma de identificação diferencial entre arbovírus circulantes em uma mesma região. Quando aplicada à identificação do vírus Ross River, também da família Togaviridae, foi possível identificar com precisão a infecção em um paciente que retornava do Norte da Austrália, excluindo outros possíveis vírus como Chikungunya, Sindbis, Kunjin e Barmah Forest, contra os quais a imunofluorescência foi negativa (TAPPE et al., 2009). Comprovadamente um teste sensível e específico, a imunofluorescência passou a ser o método de escolha para a confirmação do isolamento do vírus Chikungunya, Alphavirus mais próximo ao Mayaro, de 
acordo com o GUIA DE VIGILÂNCIA EPIDEMIOLÓGICA PARA CHIKUNGUNYA. Quanto ao alto custo e tempo para a realização de um diagnóstico por IFI, Duan et al., 2012 demonstraram que este pode ser um teste rápido com redução das quantidades de uso de anticorpos primários e secundários, possibilitando, consequentemente, maior sensibilidade e especificidade.

2.6 Células de Drosophila melanogaster (Schneider 2-S2) como suporte de antígeno para o método de Imunofluorescência indireta

O suporte utilizado neste trabalho para a expressão recombinante da proteína E2 de MAYV consiste nas células de Drosophila melanogaster S2. Dentre todas as linhagens celulares estabelecidas a partir desse inseto, as células S2 têm se destacado como instrumento de produção de proteínas heterólogas devido principalmente à facilidade de cultivo, quando comparada com células de mamíferos, à capacidade de realizar modificações póstraducionais, ao conhecimento de promotores gênicos muito eficientes e à capacidade de inserção de muitas cópias do gene de interesse diretamente no núcleo das células transfectadas, criando assim uma população com expressão estável da proteína de interesse (MCCARROL; KING, 1997). Vale ressaltar que a demanda do mercado biotecnológico por proteínas recombinantes tem sido cada vez maior, indicando que a biotecnologia apresenta o melhor custo/benefício para os setores responsáveis pela produção de produtos biológicos (AGGARWAL, 2007).

As células S2 constituem a linhagem celular mais utilizada de Drosophila. São originalmente derivadas do estágio embrionário tardio dessa espécie e caracterizadas por serem um tipo celular espontaneamente imortalizado, não clonal. Apresentam características mesodérmicas e seu comportamento e expressão gênica sugerem que são derivadas de hemócitos, macrófagos profissionais responsáveis pela fagocitose de bactérias invasoras e células apoptóticas. Morfologicamente, células S2 são esféricas, medindo de $15-20 \mu \mathrm{m}$ de diâmetro e aderem fracamente à maioria dos substratos de tecido celular (ROGERS; ROGERS, 2008). Possuem algumas características que divergem da cultura de células de mamíferos, como a temperatura e o pH do meio de cultura. A maioria das linhagens de Drosophila cresce a $25^{\circ} \mathrm{C}$ e em $\mathrm{pH}$ em torno de 6,5 , coincidentes com a temperatura e $\mathrm{pH}$ da hemolinfa. Em razão do baixo $\mathrm{pH}$ do meio, o tamponamento do sistema bicarbonato/ $\mathrm{CO}_{2}$ utilizado para cultura de células de mamíferos não é necessário (CHERBAS; GONG, 2014). Além dessas características, também apresenta um rápido crescimento e maior rendimento, 
pois alcança concentrações mais elevadas (na ordem de $10^{7-} / \mathrm{mL}$ para células $\mathrm{S} 2$ e $10^{6-} / \mathrm{mL}$ para as linhagens de mamíferos) e são capazes de expressar grandes quantidades de proteínas recombinantes (MCCARROL; KING, 1997; WURM, 2004). Desta forma, a vantagem de sua aplicação na expressão de proteínas recombinantes está na facilidade e rapidez com que uma linhagem estável é obtida, sendo o período de duas a três semanas pós-transfecção suficiente para que populações celulares altamente produtoras sejam estabelecidas (JOHANSSON et al., 2007). A linhagem S2 mostra-se, então, uma importante ferramenta econômica para área biotecnológica e, consequentemente, outra possibilidade à produção de produtos recombinantes.

Particularmente, para a detecção de anticorpos contra o vírus Mayaro (MAYV), a utilização de células de dípteros como suporte para o antígeno de interesse tem grande relevância. Pelo fato desse patógeno possuir um ciclo de infecção nessa ordem de insetos, a identidade das proteínas virais expressas nas células de inseto e de mamíferos deve ser elevada, o que assegura o desenvolvimento das células S2 como suporte para a expressão recombinante dessas proteínas virais (LELAND; GINOCCHIO, 2007). Com a construção de uma linhagem celular capaz de produzir a proteína imunogênica de interesse clínico de forma recombinante, os passos necessários para o isolamento viral são inexistentes, fato que permite a otimização de tempo e a manutenção da biossegurança.

Como método diagnóstico para o objetivo deste trabalho escolhemos a Imunofluorescência Indireta (IFI), técnica que pode ser aplicada à detecção de uma variedade de antígenos e ao diagnóstico rápido de diversas infecções virais, incluindo arboviroses. Apresenta sensibilidade suficiente para detectar subclasses de imunoglobulinas reagindo com células infectadas e permite o estudo da patogênese de doenças (AASKOV; DAVIES, 1979; BOONPUCKNAVIG et al., 1975; EL MEKKI; VAN DER GROEN; PATTYN, 1979). Baseia-se na utilização de fluorocromos, corantes que absorvem radiação luz ultravioleta emitindo luz visível, para detectar anticorpos em amostras de soro de camundongos ou humanos. Eles formam ligações covalentes com moléculas proteicas para emitir alta fluorescência no espectro visível, sendo essa diferente da emitida pelos tecidos. O fluorocromo utilizado no método diagnóstico aqui proposto para a detecção de anticorpos anti-Mayaro em amostras de soro é o Isotiocianato de Fluoresceína (FITC), que apresenta cor verde, com pico de absorção de $490 \mathrm{~nm}$ e de emissão de $520 \mathrm{~nm}$ (AOKI et al., 2010). Dados na literatura indicam que esta técnica pode ser uma ferramenta útil para o diagnóstico de Flavivirus durante surtos, pois permite detectar anticorpos $\operatorname{IgM}$ e $\operatorname{IgG}$ e, juntamente com o 
método PRNT, funciona como padrão ouro no diagnóstico de Febre Amarela, arbovírus também de grande preocupação médica (NIEDRIG et al., 2008).

Durante o desenvolvimento deste trabalho utilizamos para fins de padronização inicial do método de imunofluorescência indireta uma população de células S2 recombinantes expressando a Glicoproteína do vírus da Raiva (RVGP). Como as células expressando a RVGP já estavam disponíveis e foram amplamente estudadas pelo nosso grupo, essa abordagem foi utilizada para adiantar a fase de testes de melhores tempos de cultivo e agentes de fixação, enquanto era realizada a clonagem do gene da glicoproteína E2 do MAYV em vetores plasmidiais e sua transfecção em células $\mathbf{S} 2$ selvagens.

\subsubsection{Métodos de seleção e enriquecimento populacional para células S2}

\subsubsection{Seleção Clonal}

É sabido que as células de Drosophila não apresentam crescimento a partir de clone único sem a utilização da técnica de feeder cells, que consiste em uma cultura previamente tratada incapaz de se proliferar, porém metabolicamente funcional. Foi descrita originalmente em 1955 para células HeLa e, tradicionalmente, é obtida através do contato de uma cultura celular primária com altas doses de radiação. No entanto, recentemente o reagente Mitomicina C tem se tornado uma alternativa para essa técnica quando da utilização de células de mamífero. O reagente Mitomicina C, produzido por Streptomyces caespitosus, é um antibiótico antitumoral que inibe a separação da dupla fita de DNA durante a replicação celular através da formação de ligações covalentes entre as fitas opostas. Portanto, provoca inibição da síntese de DNA enquanto a síntese de RNA e proteínas continua normalmente, mantendo as células vitais, porém incapazes de se dividir (PONCHIO et al., 2000).

Em razão da característica de dependência de uma concentração inicial mínima de inóculo para crescimento, própria de cultivo de células de inseto (MORAES; AUGUSTO; CASTILHO, 2007), a técnica de seleção clonal para linhagens S2 recombinantes precisou ser adaptada para o cultivo concomitante com a linhagem selvagem. A célula a ser clonada deve ser diluída em uma suspensão de cultura inicial e então dispensada em placa de 96 poços ou, alternativamente, a cultura original, que funcionará como feeder cells, pode ser inoculada em placa de 96 poços e, em seguida, um único clone viável é adicionado a cada poço (CHERBAS; GONG, 2014). Sendo assim, após a obtenção de uma confluência de 100\% no cultivo contendo a cultura primária selvagem e o clone, é adicionado reagente de seleção, para 
o qual as células originais são sensíveis, enquanto que as células transfectadas são resistentes. A abordagem de feeder cells tem sido aplicada com sucesso em processos de seleção clonal (CHERBAS; GONG, 2014).

\subsubsection{Seleção Imunomagnética MACs}

A estratégia de seleção positiva através de colunas Miltenyi consiste na separação magnética de células alvo e a sua coleta para posterior cultivo. Esta técnica oferece a vantagem de alta especificidade para o isolamento de células de alta pureza quanto à expressão do antígeno pesquisado e permite o cultivo, entre outras aplicações, das células marcadas logo após o procedimento de separação MACs. Além disso, não há a necessidade de remoção das microbeads das células devido ao tamanho (aproximadamente $50 \mathrm{~nm}$ de diâmetro, comparável ao tamanho de uma partícula viral) e composição das mesmas (polissacarídeo e óxido de ferro), que as tornam biodegradáveis. Fator relevante que precisa ser levado em consideração é que a utilização das microbeads não ativam ou influenciam na função ou viabilidade celular, o mesmo sendo válido para a aparência microscópica (MACS MILTENYI BIOTEC, 2011). A técnica MACs, através de seleção positiva, pode ser aplicada para a maioria das marcações específicas, permitindo pureza, excelente recuperação das células marcadas e isolamento de células raras quando nenhuma etapa de separação subsequente é necessária (MACS MILTENYI BIOTEC, 2011).

Esta técnica de enriquecimento populacional foi aplicada para células S2 expressando a glicoproteína E2 de MAYV, pois apresentou resultados satisfatórios com a mesma linhagem celular expressando a glicoproteína RVGP na membrana, de forma que a avaliação qualitativa por IFI permitiu verificar o aumento notório na expressão dessa última (SANTOS et al., 2016). Portanto, resultados similares eram esperados para a proteína E2 após a seleção imunomagnética. 


\section{OBJETIVOS}

\subsection{Objetivo Geral}

$\checkmark$ Obter um procedimento de imunofluorescência para diagnóstico de anticorpos contra o vírus Mayaro em amostras de soro, utilizando como suporte células S2 expressando o antígeno de interesse.

\subsection{Objetivos Específicos}

$\checkmark$ Obter linhagens de células S2 expressando antígenos de superfície (glicoproteínas estruturais) do vírus Mayaro;

$\checkmark$ Padronizar um procedimento de imunofluorescência, tendo células S2 como suporte, para a identificação de anticorpos anti-glicoproteína da raiva em soro de camundongos imunizados com vacina de raiva;

$\checkmark$ Padronizar um procedimento de imunofluorescência, tendo células S2 como suporte, para a identificação de anticorpos anti-Mayaro em soro de camundongos infectados com vírus Mayaro;

$\checkmark$ Padronizar um procedimento de imunofluorescência, tendo células S2 como suporte, para a identificação de anticorpos anti-Mayaro em soro de humanos infectados com vírus Mayaro, verificando a sua sensibilidade e especificidade. 


\section{MATERIAL E MÉTODOS}

\subsection{Clonagem em vetores plasmidiais}

\subsubsection{Gene sintético das proteínas E3 e E2 do vírus Mayaro (E3E2MAYV)}

Os genes que codificam para as proteínas E3 e E2 do MAYV foram obtidos na forma de gBlock Gene Fragments (IDT Technologies (Integrated DNA Technologies, Iowa, Estados Unidos da América,)), de acordo com a sequência enviada (Figura 6).

Figura 6 - Gene sintético gBlock contendo as proteínas E3 e E2 do MAYV com os sítios de enzimas de restrição.

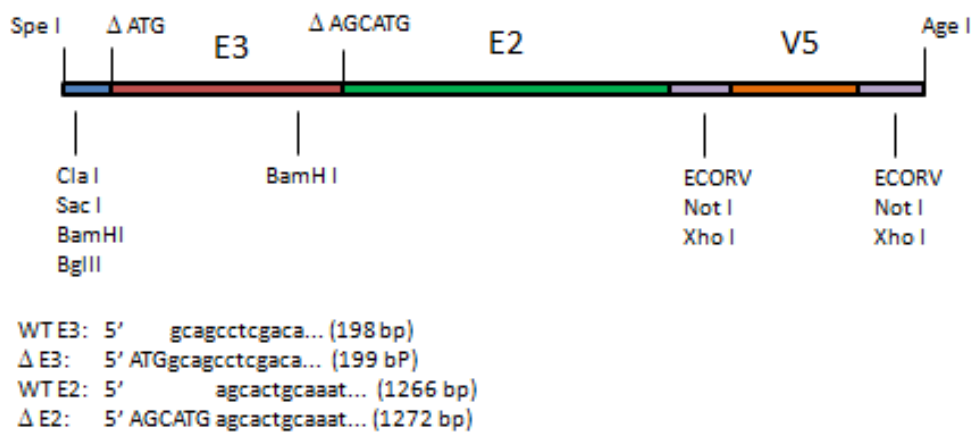

Para a construção do gene sintético, foi introduzido um códon de iniciação antes do gene da proteína E3 ( $\triangle \mathrm{ATG})$, ausente na sequência original. A proteína E3 foi inserida no gene sintético pois funciona como peptídeo sinal para a translocação da glicoproteína E2 à membrana plasmática. Através de uma troca conservativa de um nucleotídeo, foi inserido um sítio BamHI na porção final da proteína E3, de modo a possibilitar sua retirada da construção em caso de interferir na expressão da proteína E2. Os três primeiros nucleotídeos da proteína E2 foram preservados para a conservação da junção entre E3 e E2, conservando, portanto, o sítio das peptidases presentes no complexo de Golgi, responsáveis pela clivagem dessas proteínas. Foi introduzido o códon de iniciação a partir desses nucleotídeos ( $\triangle$ AGCATG) para a expressão da E2 sem a proteína E3. O epítopo V5 apresentado na figura 6 foi inserido como uma segunda alternativa à detecção de E2, porém como não foi utilizado ao longo do trabalho, será considerado futuramente apenas para a referência do tamanho do fragmento nas clonagens em que foi utilizada a enzima AgeI. 


\subsubsection{Amplificação e clonagem do gene sintético E3E2MAYV em vetor intermediário}

O fragmento gBlock sintético E2E2MAYV foi amplificado por PCR convencional utilizando os oligonucleotídeos MAYV-R: 5'-ACCGGTACGCTCGAGAG e MAYV-F: 5'-

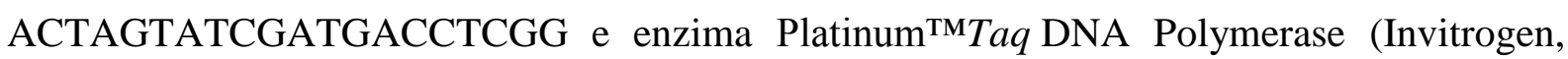
Califórnia, Estados Unidos da América), conforme as instruções do fabricante. O ciclo de amplificação utilizado foi de $95^{\circ} \mathrm{C} / 10 \mathrm{~min} ; 45 \mathrm{x}\left(95^{\circ} \mathrm{C} / 30 \mathrm{~s}, 53{ }^{\circ} \mathrm{C} / 30 \mathrm{~s}, 74{ }^{\circ} \mathrm{C} / 1 \mathrm{~min} 45\right.$ s), seguidos de $72{ }^{\circ} \mathrm{C}$ por 10 minutos. Após a amplificação por PCR convencional, o fragmento foi clonado na razão molar de 3:1 (inserto : vetor), por atividade da enzima T4 DNA Ligase (Thermo Scientific ${ }^{\circledR}$ ), no plasmídeo pGEM®-T Easy Vector (Promega, Wisconsin, Estados Unidos da América), vetor linearizado, contendo a base nitrogenada timina em ambas as extremidades 3', regiões de clonagem do inserto, o que melhora a eficiência de ligação de produtos de PCR, impedindo a recircularização do vetor (Figura 7).

\section{Figura 7 - Mapa do vetor pGEM®-T Easy Vector.}

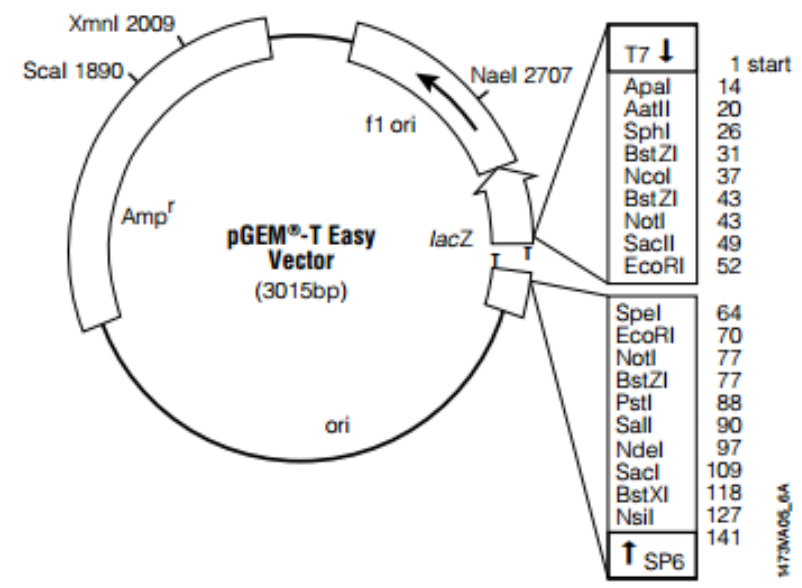

Pontos de referência da sequência de pGEM®-T Easy Vector: sítio T7 de iniciação de transcrição da RNA polimerase (1); região de clonagem múltipla (10-128); promotor SP6 de RNA polimerase promoter $(-17 \mathrm{a}+3)$ (139-158); sítio SP6 de iniciação de transcrição de RNA polimerase (141); sítio de de ligação pUC/M13 para primer de sequenciamento reverso (176-197); códon de iniciação lacZ (180); operador lac (200-216); região codificante de $\beta$-lactamase (1337-2197); região fago f1 (2380-2835); sequências óperon lac (2836-2996, 166395); sítio de ligação pUC/M13 para primer senso de sequenciamento (2949-2972); promotor T7 de RNA polimerase $(-17 \mathrm{a}+3)(2999-3)$. Fonte: Promega (2015).

Bactérias DH5 $\alpha$ quimiocompetentes foram, então, transformadas por choque térmico conforme descrito por HANAHAN, 1983. 


\subsubsection{Bactéria utilizada nas etapas de construção}

A bactéria utilizada nos procedimentos de microbiologia molecular para a construção dos vetores plasmidiais deste estudo foi Escherichia coli DH5 $\alpha$, genótipo supE44 $\Delta$ lacU 169 ( $\$ 80$ lacZ $\Delta$ M15) hasd R17 rec A1 endA1 gyrA96 thi-1 relA1.

\subsubsection{Meios de cultura para cultivo de $\mathrm{DH} 5 \alpha$}

Nos procedimentos de cultivo da bactéria $\mathrm{DH} 5 \alpha$ foi utilizado o meio Difco $^{\mathrm{TM}}$ LB Broth, Miller (Luria-Bertani), da BD Biosciences (BD Biosciences, Califórnia, Estados Unidos da América), com e sem ágar, na presença de antibiótico Ampicilina.

\subsubsection{Deteç̧ão de colônias positivas por PCR Convencional}

As colônias obtidas após transformação bacteriana com a ligação pGEM®-T Easy Vector + produto de PCR (E3E2MAYV) foram cultivadas em placa de petri contendo meio LB com ágar e antibiótico Ampicilina (100 ug/mL) (Sigma-Aldrich,Missouri, Estados Unidos da América) e, na sequência, repicadas em nova placa contendo antibiótico Ampicilina com o auxílio de um palito de dente estéril e o restante do material foi colocado em microtubo estéril para análise por PCR convencional tendo como alvo o fragmento de interesse. A presença de um fragmento de 439 pares de bases, correspondente à amplificação de uma região interna da proteína E2 do vírus Mayaro, visualizado em gel de agarose 1,5\%, indicou os clones positivos. Para a realização da PCR, 2 uL de Água Nuclease Free e 23 uL de mix de PCR (água nuclease free, tampão $10 \mathrm{x}$ sem $\mathrm{MgCl}, 50 \mathrm{mM}$ de $\mathrm{MgCl}_{2}, 10 \mathrm{mM}$ de dNTP, $20 \mathrm{uM}$ de primers senso e anti-senso e 1,25 Unidades de enzima Taq DNA Polimerase, todos os reagentes da Invitrogen ${ }^{\mathrm{TM}}$ ) foram adicionados em cada colônia, seguidos dos ciclos de amplificação: $95{ }^{\circ} \mathrm{C}$ por 10 minutos; 45 ciclos de $95{ }^{\circ} \mathrm{C}$ por 30 segundos, $53{ }^{\circ} \mathrm{C}$ por 30 segundos e $72{ }^{\circ} \mathrm{C}$ por 30 segundos, seguidos de $72{ }^{\circ} \mathrm{C}$ por 10 minutos.

Os primers senso e anti-senso utilizados foram sintetizados pela empresa IDT $^{\circledR}$ Integrated DNA Technologies e apresentam as seguintes sequências: 
Tabela 3 - Sequência dos primers utilizados na PCR Convencional para confirmação da presença de inserto nas clonagens dos vetores genéticos.

\begin{tabular}{lc}
\hline Primer & Sequência (5'--- 3') \\
\hline MYE2 313F & $5^{\prime}-$ TGTCCACCTGGCGAAC $-3^{\prime}$ \\
\hline MYE2 751R & $5^{\prime}-$ TGCGCTCTGCTTGCATC $-3^{\prime}$
\end{tabular}

As colônias que apresentaram o fragmento esperado passaram pelos processos de Miniprep por Lise Alcalina e Maxiprep por Kit ${ }^{\odot}$ QIAGEN Plasmid Maxi (Qiagen, Hilden, Alemanha) para extração dos plasmídeos de interesse.

4.1.6 Miniprep - Lise Alcalina (adaptação da técnica de BIRNBOIM e DOLY, 1979) e Maxiprep (') QIAGEN Plasmid Maxi Kit)

Para a extração de todos os plasmídeos bacterianos em pequena escala por lise alcalina, a colônia de interesse foi inoculada em $\mathrm{ml}$ de meio LB sem ágar contendo antibiótico Ampicilina $(100 \mu \mathrm{g} / \mathrm{mL})$ a $37{ }^{\circ} \mathrm{C}, 250 \mathrm{rpm}$ durante 16 horas. Os plasmídeos extraídos foram posteriormente confirmados por digestão com enzimas de restrição BshTI (AgeI) e SpeI (Thermo Scientific ${ }^{\circledR}$, Massachusetts, Estados Unidos da América). Duas colônias com correto padrão de digestão foram inoculadas em $200 \mathrm{~mL}$ de meio LB líquido para realização de Maxiprep utilizando o Kit ${ }^{\odot}$ QIAGEN Plasmid Maxi. Nesta etapa, a colônia foi inoculada em $200 \mathrm{ml}$ de meio LB, sem ágar, a $37{ }^{\circ} \mathrm{C}, 250 \mathrm{rpm}$ durante 16 horas contendo o antibiótico Ampicilina (100 $\mu \mathrm{g} / \mathrm{mL})$. Para confirmação final do plasmídeo obtido, foi realizada digestão enzimática com BshTI (AgeI) / SpeI (Thermo Scientific ${ }^{\odot}$ ), ECORI/NotI e somente com SpeI. Um dos vetores pGEM obtidos, contendo o gene sintético E3E2MAYV, após sequenciamento pelo método de Sanger, foi denominado pGEMMAYV e utilizado como vetor intermediário para a clonagem do inserto nos vetores comerciais pMT/V5-HisA e pMT/Bip/V5-HisC (Invitrogen ${ }^{\mathrm{TM}}$ ).

4.1.7 Clonagem do gene sintético nos vetores comerciais pMT/V5-HisA e pMT/BiP/V5-HisC Drosophila Expression Vector (Invitrogen ${ }^{T M}$ )

$\mathrm{O}$ inserto anteriormente clonado no vetor pGEM-T Easy foi retirado utilizando as enzimas ECORI e NotI (Fermentas ${ }^{\odot}$ ), as mesmas usadas para digerir o vetor comercial pMT/V5-HisA (Invitrogen ${ }^{\mathrm{TM}}$ ). Para a clonagem em pMT/Bip/V5-HisC, as enzimas utilizadas 
para digerir o plasmídeo e retirar o inserto de pGEM-T Easy foram NCOI e BshTI (AgeI) (Thermo Scientific ${ }^{\circledR}$ ). Abaixo estão representados os mapas dos vetores com as regiões de polylinker em destaque (Figura 8).

Figura 8 - Mapa dos vetores pMT/V5-His (A); pMT/Bip/V5-His (B).

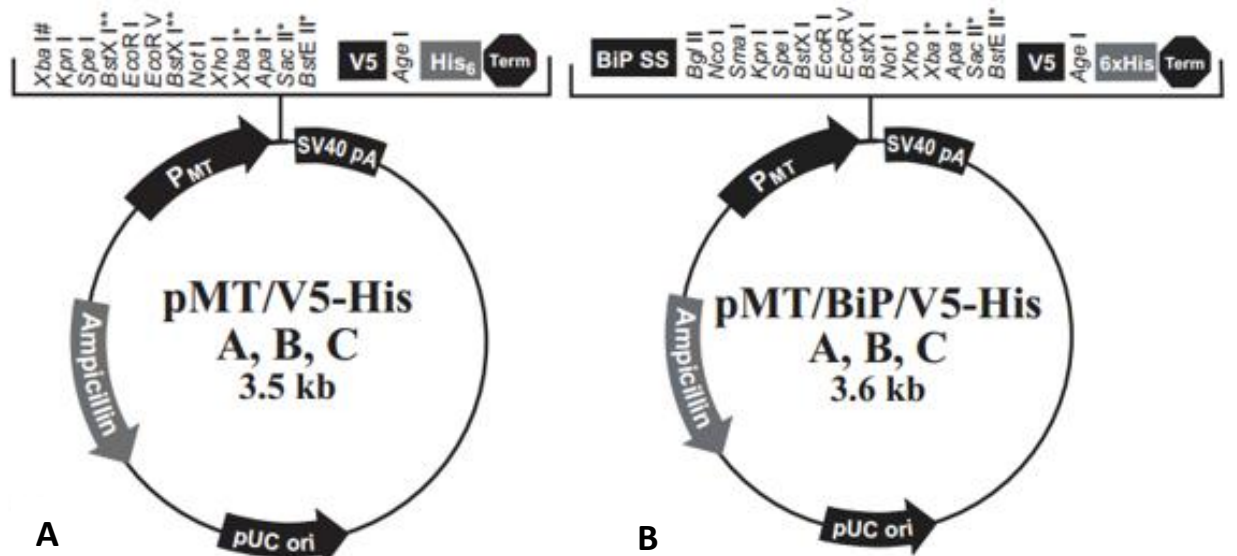

Pontos de referencia da sequência de pMT/V5-HisA: promotor de Metalotioneína (412-778); início da transcrição (778); sítio senso de MT (814-831); sítio de múltipla clonagem (854-923); epítopo V5 (930-971); região de polihistidina (981-1001); sítio anti-senso de BGH (1021-1038); sinal SV40 de poliadenilação (11631168); origem pUC (1601-2334) (complementary strand); promotor bla (3340-3438) (complementary strand); ORF do gene de resistência à Ampicilina (bla) (2479-3339) (complementary strand); pMT/Bip/V5-HisC: promotor de Metalotioneína (412-778); início da transcrição (778); sítio senso de MT (814-831); sequência sinal Bip (851-904); sítio de múltipla clonagem (906-999); epítopo V5 (1003-1044); região de polihistidina (10541074 ); sítio anti-senso de BGH (1094-1111); sinal SV40 de poliadenilação (1267-1272 ); origem pUC (17652438) (complementary strand); promotor bla (3444-3542 (complementary strand); ORF do gene de resistência à Ampicilina (bla) (2583-3443 (complementary strand). Fonte: Invitrogem ${ }^{\mathrm{TM}}$ (2015).

As digestões foram realizadas a $37{ }^{\circ} \mathrm{C}$ por 3 horas e as enzimas inativadas por temperatura (NotI $80{ }^{\circ} \mathrm{C}$ por 5 minutos; ECORI $65^{\circ} \mathrm{C}$ por 20 minutos; NCOI $65{ }^{\circ} \mathrm{C}$ por 15 minutos; BshTI (AgeI) $80{ }^{\circ} \mathrm{C}$ por 5 minutos). Os padrões de digestão foram observados após a corrida em gel de agarose $0,8 \%$. Os produtos de digestão (vetores comerciais pMT/V5-HisA e pMTBip/V5-HisC linearizados; insertos retirados de pGEMMAYV) foram cortados diretamente do gel de agarose $0,8 \%$, purificados utilizando o kit Wizard ${ }^{\circ}$ SV Gel and PCR Clean-Up System (Promega) e ligados pela T4 DNA Ligase (Thermo Scientific ${ }^{\circledR}$ ) na razão molar 1:1 de vetor:inserto para pMT/V5-HisA e inserto digerido com ECORI/NotI, 2:1 e 3:1 para pMTBip/V5-HisC e inserto digerido com NCOI/BshTI (AgeI). A dupla digestão enzimática NCOI/BshTI(AgeI) foi prioridade na construção do vetor genético pMTBipMAYV(E3E2V5) pois possibilita a retirada da maioria dos sítios de restrição presentes na região de polylinker do pMTBip/V5-HisC (Figura 9). Após a construção do vetor pMTBipMAYV(E3E2V5) foi necessário realizar uma digestão com enzima Bgl II 
$\left(\right.$ Thermo Scientific $^{\odot}$ ) para a retirada de um stop codon criado a partir da clonagem. Todas as reações enzimáticas foram realizadas de acordo com as instruções dos fabricantes.

Figura 9 - Região de polylinker de pMTBip/V5-HisC. Em destaque estão representados os sítios de restrição utilizados durante a clonagem. AGgGgGgatc cGatctcaAT ATG Aag TTA TGC ATA TTA CTG GCC GTC GTG GCC TTT Met Lys Leu Cys Il Leu Leu Al a Val Val Al a Phe

887 GTT GGC CTC TCG CTC GGG AGATCTCCAT GGCCCGGGGT ACCTACTAGT CCAGTGTGGT

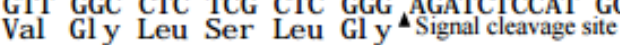
EcoR I EcoR V BstXI Not I Xho I BstEII

945 GGAATTCTGC AGATATCCAG CACAGTGGCG GCCGCTCGAG GTCACCCATT CGAA GGT AAG CCT 1008 ATC CCT AAC CCT CTC CTC GGT CTC GAT TCT ACG CGT ACC GGT CAT CAT CAC CAT Ile Pro Asn Pro Leu Leu Gly Leu Asp Ser Thr Arg Thr Gly His His His His Fonte: Invitrogen ${ }^{\mathrm{TM}}$ (2015).

\subsubsection{Análise de colônias transformadas por PCR e por padrão de digestão enzimática}

As colônias obtidas após a transformação com os plasmídeos construídos a partir da ligação com T4 ligase foram avaliadas por PCR para a presença do fragmento de interesse utilizando. A presença de um produto de amplificação de 439 bp indicou as colônias positiva. Após a verificação por PCR, as colônias positivas foram cultivadas e os plasmídeos extraídos em pequena ou grande escala (Mini ou Maxiprep) para avaliação por padrão de digestão com enzimas de restrição: pMTMAYV(E3E2V5) foi digerido com ECORI/NotI e PvuII, pMTBipMAYV(E3E2V5) foi digerido com BamH I para confirmação da construção. O padrão de bandas a ser observado foi confirmado pela utilização do programa NEBcutter V2.0 (BioLabs, Massachusetts, Estados Unidos da América), que permite digerir uma sequência de DNA determinada com as enzimas que se pretende utilizar, obtendo o padrão de restrição esperado.

\subsection{Obtenção de células S2MtMAYV(E3E2) e S2MtBipMAYV (E3E2V5)}

No dia anterior à transfecção, células S2 selvagens foram repicadas em frasco T25 para conter $5 \times 10^{6}$ células totais. Para a transfecção foi utilizada Cellfectina ${ }^{\circledR}$ II (Invitrogen ${ }^{\mathrm{TM}}$ ), um lipídeo catiônico desenvolvido para células de inseto, conforme protocolo estabelecido anteriormente (LEMOS, 2009). Foram utilizados $20 \mu \mathrm{g}$ dos vetores de expressão pMTMAYV(E3E2) e pMTBipMAYV(E3E2V5), este último contendo o sinal de secreção Bip para o direcionamento do RNAm ao retículo endoplasmático e à via de secreção de 
proteínas (LEMOS, 2009), e $1 \mu \mathrm{g}$ de vetor de seleção pCoHygro, o qual apresenta o gene de resistência ao antibiótico Higromicina B (Invitrogen ${ }^{\mathrm{TM}}$ ). A solução de transfecção contendo meio de cultura SF-900III, Cellfectina ${ }^{\circledR}$ II e vetores de expressão e de seleção foi mantida na cultura por 48 horas a $28{ }^{\circ} \mathrm{C}$ para aumentar a eficiência de transfecção e retirada por centrifugação (2400 rpm por 5 minutos), seguida de troca do meio de cultura. O antibiótico Higromicina B (Invitrogen ${ }^{\mathrm{TM}}$ ) foi adicionado na cultura transfectada e selvagem na concentração de $600 \mu \mathrm{g} / \mathrm{mL}$ durante trinta dias para a seleção das células resistentes. Após a morte das células selvagens, a pressão seletiva foi cessada e as populações S2MtMAYV(E3E2) e S2MtBipMAV(E3E2V5) foram consideradas estabelecidas. Duas novas seleções sequenciais com o antibiótico Higromicina B, por um período de 15 dias na concentração de $600 \mu \mathrm{g} / \mathrm{mL}$, foram realizadas nas populações S2MtMAYV(E3E2) e S2MtBipMAYV(E3E2V5) na tentativa de obter maior expressão de E2. Quando as linhagens reselecionadas foram novamente estabelecidas, passaram pelo processo de congelamento em nitrogênio líquido para posterior utilização. A composição do meio de congelamento obedeceu às seguintes proporções: $50 \%$ de Soro Fetal Bovino, $40 \%$ de meio SF-900TMIII SFM $\left(\right.$ Gibco $\left.^{\circledR}\right)$ e $10 \%$ de Dimethyl Sulfoxide (DMSO) $\left(\right.$ Sigma-Aldrich $\left.^{\circledR}\right)$.

4.3 Métodos de seleção/ enriquecimento populacional das linhagens S2MtMAYV(E3E2) e S2MtBipMAYV(E3E2V5)

\subsubsection{Seleção clonal das linhagens S2MtMAYV(E3E2) e S2MtBipMAYV(E3E2V5)}

Para a seleção do clone viável a partir das linhagens S2MtMAYV(E3E2) e S2MtBipMAYV(E3E2V5), foi necessário estabelecer um protocolo de seleção de células S2 recombinantes, uma vez que o procedimento não havia sido realizado anteriormente no laboratório. Dessa forma, cabe uma descrição mais detalhada do procedimento realizado. Primeiramente, foi padronizada uma quantidade inicial ideal de células S2 selvagens por poço em placa de 96 poços para permitir o desenvolvimento adequado desta cultura primária antes da adição de um clone recombinante viável, caracterizando, desta forma, a técnica de feeder cells. Foram testadas as concentrações de $4 \times 10^{4}$ e $4 \times 10^{5}$ células totais/poço, sendo a primeira a melhor condição encontrada pois permitiu a criação de espaços na cultura primária onde o clone poderia apresentar crescimento na forma de colônia. A interrupção do crescimento da linhagem selvagem foi realizada em paralelo ao teste de citotoxicidade do reagente Mitomicina C (Sigma-Aldrich ${ }^{\circledR}$ ) em cultura de células S2 selvagens, de forma a 
observar a melhor concentração em que as mesmas não apresentariam crescimento, porém sem efeito citopático que pudesse vir a prejudicar a subcultura de clones viáveis.

Células S2 selvagens foram, então, cultivadas em placa de 96 poços, na concentração de $4 \times 10^{4}$ células totais por poço, durante o período de 24 horas. Após atingir uma confluência de, aproximadamente, $80 \%$, foi adicionado o reagente Mitomicina C nas seguintes concentrações: $0 ; 0,2 ; 1 ; 2 ; 5 ; 10$ e $20 \mu \mathrm{g} / \mathrm{mL}$, conforme anteriormente testado por PONCHIO et al., 2000 em linhagens de fibroblastos murinos. Três padrões diferentes foram observados após a adição do reagente: indício de proliferação, estado de confluência e morte celular (CHERBAS; GONG, 2014). Após os períodos de 3, 20 e 24 horas de ação da Mitomicina $\mathrm{C}$ sobre a cultura selvagem, o reagente foi retirado, seguido de 3 lavagens com meio de cultura SF-900 ${ }^{\mathrm{TM}}$ III SFM e adição de $200 \mu \mathrm{L}$ do mesmo meio contendo $20 \%$ de soro fetal bovino, afim de minimizar quaisquer danos às células. A partir do quinto dia da retirada do reagente Mitomicina $\mathrm{C}$, foi realizada a contagem de células viáveis até o oitavo dia para verificar se o crescimento celular havia sido alterado e qual a concentração do reagente que melhor preservou a cultura sem observação de efeito citopático. Os melhores parâmetros de cultivo para seleção clonal foram determinados como: inóculo de $4 \times 10^{4}$ de células $\mathrm{S} 2$ por poço em placa de 96 poços, seguida da adição de $0,2 \mu \mathrm{g} / \mathrm{mL}$ de Mitomicina $\mathrm{C}$ por um período de 3 horas,realização de 3 lavagens com meio de cultura para a retirada do reagente e, após 5 dias, adição das células submetidas à seleção clonal.

Para a realização da seleção clonal a partir das linhagens S2MtMAYV(E3E2) e S2MtBipMAYV(E3E2V5) foram estabelecidas suspensões celulares com concentração inicial de 10 células $/ \mathrm{mL}$, das quais $100 \mu \mathrm{L}$ foram transferidos para cada poço contendo, previamente, $100 \mu \mathrm{L}$ de meio SF-900 ${ }^{\mathrm{TM}}$ III SFM e células S2 previamente tratadas com Mitomicina C.

Após as culturas contendo os clones de S2MtMAYV(E3E2) e S2MtBipMAYV(E3E2V5) atingirem 100\% de confluência nas placas de 96 poços, foi realizada a passagem para placa de 24 poços para expandir a população celular. A troca do meio de cultura ocorreu semanalmente, com 1,0 mL de volume final por poço, com adição de $40 \mu \mathrm{g} / \mathrm{mL}$ do antibiótico Higromicina B. Após a confluência atingir $100 \%$ nos poços das placas de 24 poços, a concentração do antibiótico foi aumentada para $300 \mu \mathrm{g} / \mathrm{mL}$ durante três a quatro dias, período em que foi observada a formação de debri celular, decorrente da morte das feeder cells e células que perderam o marcador de resistência. O meio de cultura foi, então, trocado por meio novo e a concentração inicial de $40 \mu \mathrm{g} / \mathrm{mL}$ do antibiótico reestabelecida por um período de duas semanas, para manutenção da pressão seletiva basal 
quando, em seguida, apenas o meio de cultura era adicionado às células. Após um mês de crescimento celular na placa de 24 poços sem adição de antibiótico, os clones foram transferidos para placas de 12 poços e a concentração de $600 \mu \mathrm{g} / \mathrm{mL}$ foi reconstituída por um período de duas semanas para estabelecer as populações de interesse. Após este período de seleção na presença de antibiótico, um poço de cada linhagem apresentou uma população que se manteve estável e resistente à Higromicina B. Foram nomeadas como S2MtMAYV(E3E2)_SC e S2MtBipMAYV(E3E2V5)_SC.

\subsubsection{Enriquecimento populacional das linhagens S2MtMAYV(E3E2) e} S2MtBipMAYV(E3E2V5) por seleção imunomagnética MACs (Miltenyi Biotec)

Para a realização da técnica, as linhagens celulares S2MtMAYV(E3E2) e S2MtBipMAYV(E3E2V5) foram induzidas com $1 \mathrm{mM}$ de CuSO4 em frascos $\mathrm{T} 75$ de cultivo para a expressão da glicoproteína de membrana E2. Após 6 dias, condizente a 144 horas pósindução, foram separadas $3,4 \times 10^{7}$ células totais, centrifugadas a $1000 \mathrm{rpm}$ por 5 minutos a 7 ${ }^{\circ} \mathrm{C}$ para eliminar o meio de cultura e lavadas com PEB (PBS EDTA 2 mM BSA 0,5\%). Em seguida, o precipitado celular foi ressuspendido em $340 \mu \mathrm{L}$ de PEB, a que foram adicionados $10 \mu \mathrm{L}$ do anticorpo primário Soro Hiperimune de camundongo anti-MAYV, e incubado a 4 ${ }^{\circ} \mathrm{C}$ por 10 minutos, sendo posteriormente lavado por duas vezes adicionando 3,4 $\mathrm{mL}$ de PEB. O sobrenadante foi, então, removido, o precipitado celular ressuspendido em $272 \mu \mathrm{L}$ de PEB e $68 \mu \mathrm{L}$ de microbeads e incubado por 15 minutos a $4{ }^{\circ} \mathrm{C}$, seguido de uma lavagem com 3,4 $\mathrm{mL}$ de PEB. O sobrenadante foi descartado e $500 \mu \mathrm{L}$ de PEB foram adicionados ao pellet. A coluna para separação das células foi preparada com $500 \mu \mathrm{L}$ de PEB e a suspensão celular aplicada, descartando o que passava diretamente pela coluna. Esta foi lavada por três vezes com PEB, removida do separador magnético e posicionada em tubo coletor estéril. Foi adicionado 1,0 mL de meio de cultura SF-900 ${ }^{\mathrm{TM}}$ III SFM e as células eluídas com o auxílio de um êmbolo. O princípio da técnica segue conforme a ilustração abaixo. 
Figura 10 - Princípio da técnica de separação imunomagnética.
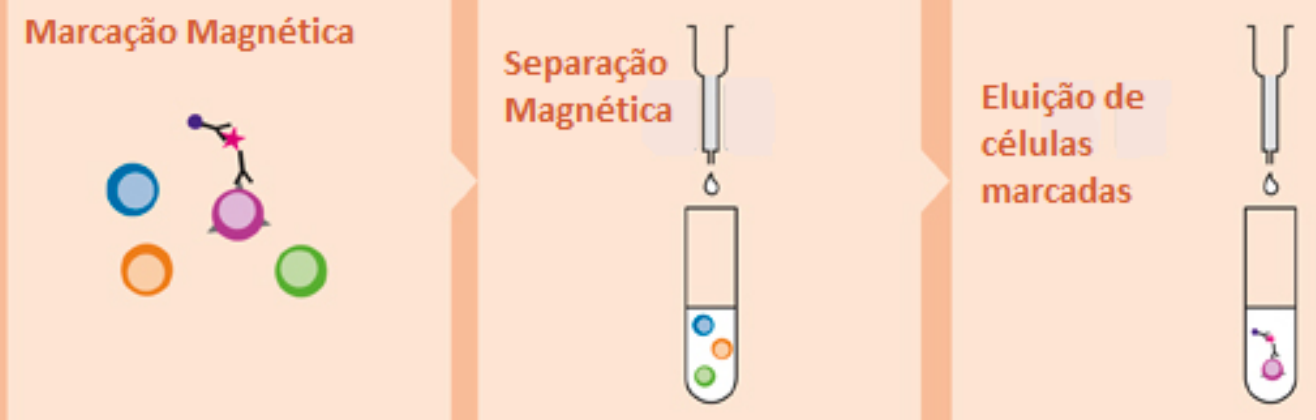

A marcação das células foi feita com o anticorpo primário anti-MAYV e microbeads, seguida de aplicação da suspensão celular na coluna, pela qual passaram as células não-marcadas que foram descartadas e, por fim, aquelas com marcação foram eluídas e cultivadas. Fonte: Miltenyi Biotec MACs (2016).

O conteúdo celular marcado e coletado foi cultivado em placa de 12 poços até atingir a confluência de $100 \%$ para a transferência à placa de 6 poços e frascos T25. Posteriormente, foi feito o congelamento em nitrogênio líquido apenas da linhagem S2MtMAYV(E3E2)_M1, visto que não foi obtida com sucesso o enriquecimento populacional da linhagem S2MtBipMAYV(E3E2V5).

4.4 Padronização da técnica de Imunofluorescência indireta utilizando como suporte de antígeno células $S 2$ expressando a glicoproteina do vírus da raiva $(R V G P)$ e a glicoproteína E2 do vírus Mayaro

\subsubsection{Estudo primário com células expressando a glicoproteína do vírus da raiva (RVGP)}

Para a padronização inicial da técnica de imunofluorescência indireta (IFI), quando ainda as linhagens recombinantes expressando a glicoproteína do vírus Mayaro eram obtidas, foi utilizada a população celular recombinante S2MTRVGPHy-M3 (SANTOS et al., 2016), originada da linhagem S2MtRVGPMc7 (LEMOS, 2009) que expressa a glicoproteína do vírus da raiva (RVGP). O enriquecimento populacional realizado para Mc7 foi feito através de seleção imunomagnética MACs (MACs, Mylteni Biotec, Bergisch Gladbach) para aumentar a produção de RVGP/célula, obtendo, assim a linhagem S2MTRVGPHy-M3. Os resultados de padronização obtidos a partir dos primeiros testes de IFI com M3 puderam ser extrapolados de forma eficaz para as populações de S2 contendo a proteína E2 de Mayaro pois trata-se da mesma linhagem celular expressando, igualmente, glicoproteína de membrana. Estudos realizados por SANTOS et al., 2016 com a população S2MTRVGPHy-M3 permitiram obter maior conhecimento quanto às células $\mathrm{S} 2$ recombinantes e, consequentemente, contribuíram para um melhor entendimento inicial quanto àquelas que expressariam a proteína E2. 


\subsubsection{Cultivo das células S2 recombinantes expressando RVGP/E2 e adesão às lamínulas}

As etapas que antecedem a realização da técnica de imunofluorescência indireta, como tempo de cultivo na presença do agente indutor de expressão CuSO4 e aderência em lamínulas, apresentaram diferenças na sua execução devido à necessidade particular pelo correto folding de cada proteína a ser expressa (RVGP e E2) e a adaptação da padronização para minimizar gastos e melhorar a capacidade celular de adesão à superfície, respectivamente.

\subsubsection{Cultivo de Células S2MtRVGHy-M3}

As células S2MtRVGHy-M3 foram cultivadas em aderência sobre lamínulas inseridas em placa de 6 poços contendo meio livre de soro SF-900 ${ }^{\mathrm{TM}}$ III SFM, a $28{ }^{\circ} \mathrm{C}$, durante 48 horas. A expressão recombinante foi induzida pela adição de $\mathrm{CuSO}_{4}$ ao meio de cultura (700 $\mu \mathrm{M})$ um dia após o inóculo e avaliada por microscopia de fluorescência 24 horas depois.

\subsubsection{Cultivo de células S2MtMAYV(E3E2) e S2MtBipMAV(E3E2V5)}

As populações S2MtMAYV(E3E2) e S2MtBipMAV(E3E2V5) foram cultivadas em SF-900TM III SFM a $28{ }^{\circ} \mathrm{C}$, em frasco T25 durante 7 dias. A expressão recombinante foi induzida pela adição de $\mathrm{CuSO}_{4}(1 \mathrm{mM}) 24$ horas após o inóculo e avaliada por microscopia de fluorescência 144 horas depois. Um volume de $40 \mu \mathrm{L}$ de células era colocado sobre lamínulas para secagem e após cerca de 40 minutos em estufa a $37{ }^{\circ} \mathrm{C}$, as células encontravam-se aderidas.

\subsubsection{Fixação das amostras}

$\mathrm{Na}$ padronização da técnica com células S2MtRVGPHy-M3 foram testados os reagentes Metanol/Acetona 1:1, formaldeído $2 \%$ e formaldeído 4\%. A incubação para fixação foi feita por 20 minutos, sendo testadas as seguintes temperaturas: ambiente (TA), a $0{ }^{\circ} \mathrm{C}$ (sobre placa de gelo) e a $-20^{\circ} \mathrm{C}$.

O protocolo que apresentou melhores resultados (solução de Metanol/Acetona 1:1, por 20 minutos a $-20{ }^{\circ} \mathrm{C}$ ) foi utilizado para a fixação das amostras de células S2 Selvagem, 
S2MtMAYV(E3E2),

S2MtBipMAYV(E3E2V5),

S2MtMAYV(E3E2)_M1,

S2MtBipMAYV(E3E2V5)_SC e S2MtMAYV(E3E2)_SC. Para células VERO, a fixação foi feita utilizando formaldeído $4 \%$ por 10 minutos a $-20{ }^{\circ} \mathrm{C}$ para marcação com soro humano de fase aguda para infecção por ZIKV (controle positivo de imunofluorescência para Zika). Esse protocolo foi padronizado previamente também para células de mamífero (dado não representado).

\subsubsection{Marcação com anticorpos primários, secundários, soros de camundongos e humanos}

Foram utilizados para o reconhecimento da RVGP nas amostras de S2MtRVGPHyM3 os anticorpos comerciais monoclonais de camundongo C75 (RV1C5, LifeSpan) e M-D1100 (INSTITUTO PASTEUR, Paris, França); soros de camundongo e coelho, provenientes de ensaios de imunização com vacina contra a raiva e salina previamente realizados pelo grupo do Laboratório de Imunologia Viral (INSTITUTO BUTANTAN) nos anos de 2011 e 2007, respectivamente. Os anticorpos e soros foram diluídos em PBS 1X contendo Azul de Evans, que permite a marcação de proteínas do citoplasma celular. As diluições foram realizadas em diversas proporções, de maneira a encontrar a melhor condição analítica para a padronização do teste de imunofluorescência.

Para a detecção da proteína E2 de MAYV na membrana celular de S2 e, desta forma poder padronizar a técnica como teste diagnóstico para infecção pelo vírus Mayaro, foram utilizados como anticorpo primário o Soro Hiperimune de camundongo imunizado com o vírus Mayaro (ATCC, Manassas, Virgínia, Estados Unidos da América) e soros de fases aguda e covalescente de indivíduos infectados por MAYV durante surto epidêmico em cidades dos Estados do Acre e Amazonas, Brasil, gentilmente doados pelo Dr. Marcelo Urbano Ferreira, do Instituto de Ciências Biomédicas da Universidade de São Paulo e do Centro de Saúde de Acrelândia. Os soros recebidos, após exclusão da suspeita inicial por malária, tratavam-se de 5 amostras de fase aguda de infecção por MAYV, diagnosticadas por RT-qPCR em estudo feito entre os anos de 2010 e 2014 no Estado do Amazonas (no assentamento Remansinho), e 1 de fase de convalescença, coletada no Estado do Acre entre os anos de 2004 e 2006 (assentamento Granada) e confirmada para o vírus Mayaro após teste de Inibição de Hemaglutinação. Como anticorpo secundário foram utilizados anti-mouse IgG (whole molecule)-FITC antibody produced in goat (Sigma-Aldrich $\left.{ }^{\circledR}\right)$, anti-human IgM $(\mu$ chain specific)-FITC antibody produced in goat e anti-Human IgG (Fc specific)-FITC 
antibody produced in goat $\left(\right.$ Sigma-Aldrich $\left.^{\circledR}\right)$, a depender da marcação primária aplicada. Como controle do teste, para verificação de possível reação cruzada com outras arboviroses atualmente circulantes no Brasil, foram utilizadas amostras de soro de fase aguda de pacientes infectados com os vírus: Chikungunya (coletadas durante surto febril no Estado de Sergipe, Brasil, em fevereiro de 2016 e diagnosticadas como positivas pela técnica de RT-qPCR, sendo que os pacientes apresentavam febre e posteriormente apresentaram artrite/artralgia); Zika (amostra única de fase aguda detectada por ELISA para NS1 do vírus em colaboração com os Laboratórios de Bacteriologia - Unidades 1 e 2, do Instituto Butantan), ambas amostras (soro de pacientes para CHIKV ou ZIKV) foram gentilmente cedidas pela Dra. Alessandra Soares Schanoski, do Laboratório de Bacteriologia - Unidade 2 (INSTITUTO BUTANTAN); Dengue: soro de indivíduo convalescente coletado no ano de 2016 no Instituto Butantan (paciente relatou ter desenvolvido a doença há 10 anos, com diagnóstico realizado na ocasião, sendo a mesma novamente confirmada para o presente estudo pela técnica de PRNT no ano de 2016).

O soro humano utilizado como negativo para Alphavirus e para o vírus Zika foi obtido de soroteca do Laboratório de Imunologia Viral, tendo sido retirado de voluntário que não relatou ter apresentado em nenhuma fase da vida quaisquer sintomas clássicos de arboviroses. Todos os soros, de camundongo e humanos, foram, primeiramente, inativados por temperatura em banho seco $\left(56^{\circ} \mathrm{C}\right)$ durante 30 minutos para inativação das proteínas do sistema complemento a fim de evitar ligação inespecífica. Na tabela 1 estão descritos os anticorpos e as diluições utilizados durante os processos de padronização da técnica e detecção de anticorpos em amostras de soro de pacientes. 
Tabela 4 - Anticorpos primários e secundários utilizados na padronização e execução do método de Imunofluorescência Indireta.

\begin{tabular}{|c|c|c|c|}
\hline \multicolumn{2}{|c|}{ Antígeno } & Anticorpos / Amostras & Diluição em PBS 1X \\
\hline \multirow[t]{8}{*}{ RVGP } & primário & C75 (RV1C5) & $1: 500$ \\
\hline & & M-D1-100 & $1: 400$ \\
\hline & & Soro de coelho anti-vacina de raiva & $1: 200$ \\
\hline & & Soro de camundongo anti-vacina de raiva & $1: 50$ \\
\hline & & Soro de coelhos e camundongos & $1: 50$ \\
\hline & & imunizados com salina & \\
\hline & secundário & FITC-Goat anti-IgG de coelho & $1: 500$ \\
\hline & & e camundongo & \\
\hline \multirow[t]{10}{*}{ E2 } & primário & Soro Hiperimune de camundongo (ATCC) & $1: 500$ \\
\hline & & Soro de pacientes infectados (MAYV) & $1: 500$ \\
\hline & & Soro de pacientes infectados (CHIKV) & $1: 500$ \\
\hline & & Soro Humano negativo para Alphavirus & $1: 500$ \\
\hline & & Soro de paciente negativo para ZIKV & $1: 500$ \\
\hline & & Soro de paciente infectado (ZIKV) & $1: 500$ \\
\hline & & Soro de paciente infectado (DENV) & $1: 500$ \\
\hline & secundário & Goat-Anti-mouse IgG (whole molecule)-FITC & $1: 750$ \\
\hline & & Goat-Anti-Human IgM ( $\mu$-chain specific)-FITC & $1: 1500$ \\
\hline & & Goat-Anti-Human IgG (Fc specific)-FITC & $1: 1500$ \\
\hline
\end{tabular}

\subsubsection{Microscopia de fluorescência}

As amostras marcadas com os anticorpos ou soros descritos no item anterior foram visualizadas em microscópio de fluorescência Olympus BX21. As imagens foram adquiridas por meio do aplicativo Cell Sens (Olympus, São Paulo, Brasil). Todas as análises foram feitas em paralelo ao tratamento de imunofluorescência da célula recombinante que melhor expressa a proteina E2 na presença de soro de camundongo e humano negativos para o vírus Mayaro. No quadro 1 estão resumidas as etapas iniciais testadas para a padronização da imunofluorescência indireta de S2MtRVGPHy-M3, S2MtMAYV(E3E2) e S2MtBipMAYV(E3E2V5). 


\begin{tabular}{|c|c|c|c|c|c|c|}
\hline $\begin{array}{l}\text { Cultivo celular na presença } \\
\text { de } \mathrm{CuSO} 4\end{array}$ & $\begin{array}{c}\text { Análise } \\
\text { pós- } \\
\text { indução } \\
\end{array}$ & Solução de Fixação & \begin{tabular}{|c|} 
Tempoe \\
Temperatura \\
de fixação \\
\end{tabular} & Marcação - anticorpo primário & $\begin{array}{l}\text { Marcação- } \\
\text { anticorpo } \\
\text { secundário }\end{array}$ & $\begin{array}{l}\text { Tempo e temperatura de } \\
\text { marcação dos anticorpos }\end{array}$ \\
\hline \multirow{3}{*}{ S2MtRVGPHy-M3 - 2 dias } & \multirow{3}{*}{24 horas } & $\begin{array}{l}\text { Metanol/Acetona } \\
1: 1-20 \text { minutos }\end{array}$ & \multirow{3}{*}{$\begin{array}{c}20 \text { minutos } \\
\text { temperatura } \\
\text { anbiente, } \\
\text { sobre o gelo } \\
\mathrm{e}-20^{\circ} \mathrm{C}\end{array}$} & \multirow{2}{*}{$\begin{array}{c}\text { Anticorpos monoclonais de } \\
\text { camundongo (C75 (RV1C5) e } \\
\text { M-D1-100), soro de } \\
\text { camundongo imunizado com } \\
\text { vacina contra a raiva e com } \\
\text { salina } \\
\end{array}$} & \multirow{2}{*}{$\begin{array}{l}\text { FITC-Goat anti- } \\
\text { IgG de } \\
\text { camundongo }\end{array}$} & \multirow{3}{*}{$4^{\circ} \mathrm{C}$ por 1 hora } \\
\hline & & $\begin{array}{c}\text { Paraformaldeido } 2 \% \\
20 \text { minutos }\end{array}$ & & & & \\
\hline & & $\begin{array}{l}\text { Paraformadeido } 4 \% \\
20 \text { minutos }\end{array}$ & & $\begin{array}{l}\text { Soro de coetho imunizado com } \\
\text { vacina contra a raiva e com } \\
\text { salina }\end{array}$ & $\begin{array}{l}\text { FITC-Goat anti- } \\
\text { IgG de coelho }\end{array}$ & \\
\hline $\begin{array}{c}\text { S2MtMAYV(E3E2)e } \\
\text { S2MtBipMAYV(E3E2V5) } \\
7 \text { dias }\end{array}$ & 144 horas & $\begin{array}{l}\text { Metanol/Acetona } \\
1: 1-20 \text { minutos }\end{array}$ & $\begin{array}{c}20 \text { minutos a } \\
-20^{\circ} \mathrm{C}\end{array}$ & $\begin{array}{c}\text { Soro hiperimune de } \\
\text { camundongo imunizado com o } \\
\text { virus Mayaro }\end{array}$ & $\begin{array}{l}\text { FITC-Goat anti- } \\
\text { IgG de } \\
\text { camundongo }\end{array}$ & $4^{\circ} \mathrm{C}$ por 30 minutos \\
\hline
\end{tabular}

4.5 Cinética de crescimento celular - células S2 Selvagem, S2MtMAYV(E3E2), S2MtBipMAYV(E3E2V5) e sub-linhagens

As linhagens celulares S2 selvagem, S2MtMAYV(E3E2), S2MtBipMAYV(E3E2V5), S2MtMAYV(E3E2)_M1, S2MtMAYV(E3E2)_SC e S2MtBipMAYV(E3E2V5)_SC foram inoculadas em frascos Schott na concentração inicial de 1 × $10^{6}$ células $/ \mathrm{mL}$, em um volume final de $20 \mathrm{~mL}$ e mantidas sob agitação constante de $100 \mathrm{rpm}$ a $28^{\circ} \mathrm{C}$, em meio SF- $900^{\mathrm{TM}} \mathrm{III}$ SFM. Todas as linhagens foram analisadas em conjunto a critério de comparação do comportamento delas em iguais condições de crescimento.

Quando as culturas celulares alcançaram concentrações entre 3 e 5 × $10^{6}$ células $/ \mathrm{mL}$, foi adicionado $1 \mathrm{mM}$ de $\mathrm{CuSO} 4$ para induzir a expressão da proteína recombinante. Foram retiradas amostras para contagem das células a cada 24 horas até o tempo de 168 horas pósindução, correspondente ao tempo de 216 horas de cultivo. Para a determinação da concentração e viabilidade celular foram utilizados o hematocitômetro e o método de coloração com azul de Trypan $0,04 \%$.

4.6 Quantificação relativa por $R T-q P C R$ de RNA mensageiro ( $m R N A)$ da glicoproteína E2 de $M A Y V$ em linhagens de células $S 2$

As reações de RT-qPCR (Tempo Real) foram realizadas utilizando o reagente KAPA SYBR $^{\circledR}$ FAST qPCR Master Mix 2X (KAPA Biosystems, Wilmington, Estados Unidos da América) e o equipamento StepOne (Life Technologies, São Paulo, Brasil). As amostras de RNA total foram obtidas a partir de alíquotas de $3 \times 10^{6}$ células totais das culturas em Schott 
(volume final de $20 \mathrm{~mL}$, mantidas sob agitação constante de $100 \mathrm{rpm}$ a $28{ }^{\circ} \mathrm{C}$, em meio SF$900^{\mathrm{TM}}$ III SFM, retiradas nos tempos 24 a 168 horas pós-indução. O material genético foi extraído utilizando de colunas de purificação de RNA do kit PureLink $^{\circledR}$ RNA Mini Kit $\left(\right.$ Ambion $^{\mathrm{TM}}$ ), seguindo as recomendações do fabricante. As amostras de RNA (3 $\left.\mu \mathrm{g}\right)$ foram tratadas com enzima DNase para eliminar o DNA contaminante da proteína E2 anteriormente à etapa de transcrição reversa (RT). A RT foi realizada com enzima Superscript II $\left(\right.$ Invitrogen $\left.{ }^{\circledR}\right)$ e primer reverso específico $(20 \mu \mathrm{M})$ (IDT) para a glicoproteína E2 de MAYV. Quantidades padronizadas de cDNA $(2 \mu \mathrm{L})$ e de primers $(5 \mu \mathrm{M})$ para as regiões de E2 e tubulina de células S2 foram inseridas em cada reação de RT-qPCR (ASTRAY et al., 2013). O gene da tubulina de células de Drosophila melanogaster foi utilizado como controle interno (housekeeping gene) nas reações de RT-qPCR para garantir a eficiência e a reprodutibilidade dos experimentos. As quantidades relativas de mRNA de E2 foram determinadas pela utilização do seguinte modelo matemático (PFAFFL, 2001):

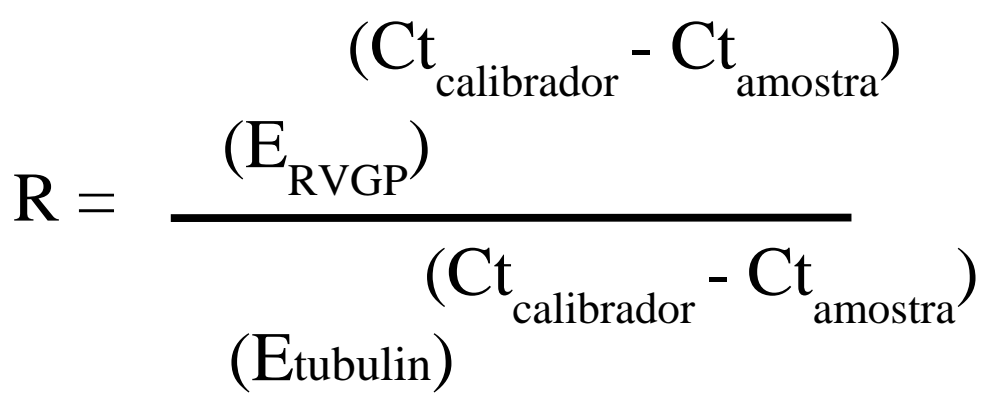

Em que: $\underline{\mathrm{R}}$ significa cálculo relativo; $\underline{\mathrm{E}}$ equivale à eficiência da reação com o uso dos primers de E2 ou Tubulina; $\underline{\mathrm{Ct}}$ do calibrador refere-se à população controle dos experimentos (tempo de menor expressão da

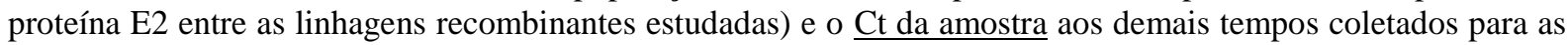
mesmas populações celulares. Fonte: Pfaffl (2001). 


\section{RESULTADOS}

5.1 Obtenção do vetor intermediário pGEMMAYV(E3E2V5)

O gene sintético foi amplificado por PCR convencional (Figura 11) utilizando os oligonucleotídeos MAYV-R e MAYV-F.

Figura 11 - Análise em gel de agarose 1,5\%. Amplificação do gene sintético por PCR Convencional.

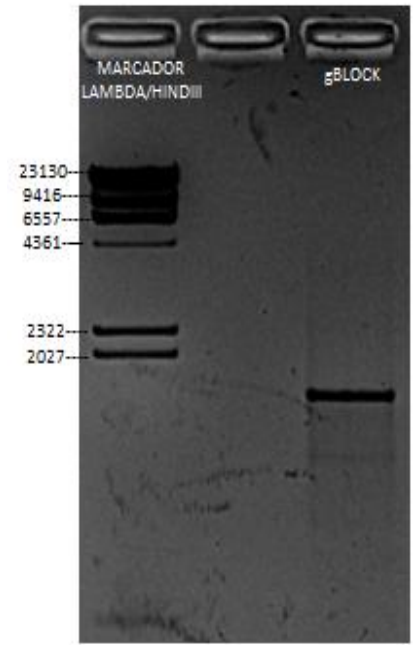

Análise em gel de agarose $0,8 \%$ do fragmento de 1617 bp, correspondente à amplificação do gene sintético de MAYV.

Após a amplificação por PCR convencional, o fragmento foi clonado no plasmídeo pGEM $^{\circledR}$-T Easy Vector (Promega) e propagado após transformação bacteriana. As colônias positivas para a construção do vetor intermediário pGEMAYV(E3E2V5) foram confirmadas por PCR. As colônias positivas para a presença do plasmídeo apresentaram um fragmento de 439 pares de bases, correspondente à amplificação de uma região interna da proteína E2 do vírus Mayaro. As amostras foram analisadas em gel de agarose 1,5\%, mostrando a presença de clones positivos (Figura 12). 
Figura 12 - Análise em gel de agarose 1,5\%. PCR das colônias positivas para a transformação com o vetor pGEMMAYV(E3E2V5)

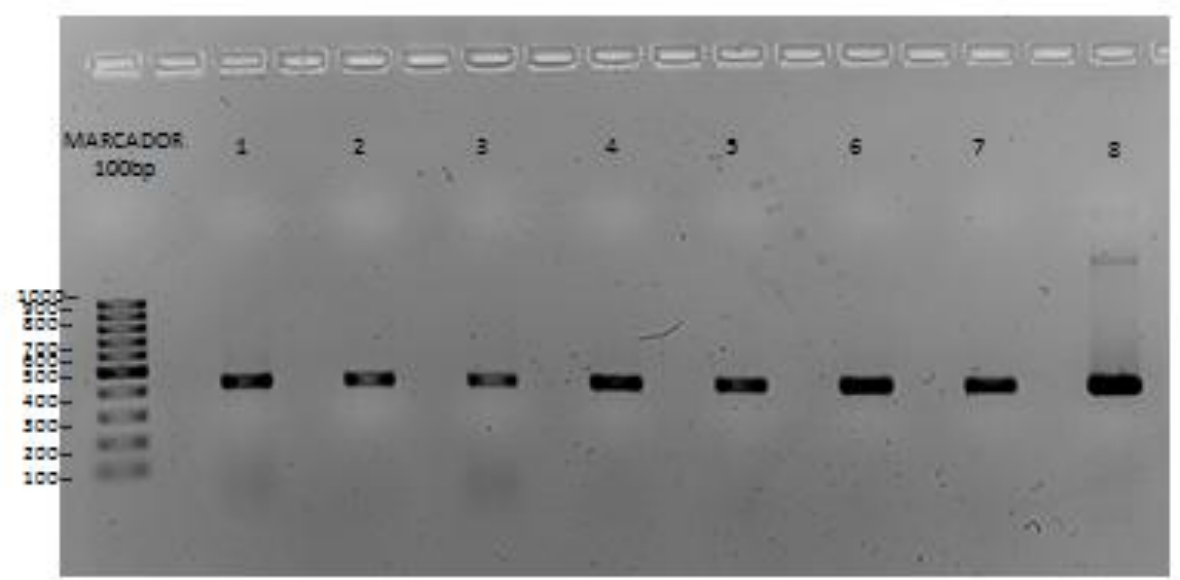

Análise em gel de agarose 1,5\% do fragmento de 439 bp, correspondente à amplificação da região da proteína E2 do MAYV nas colônias positivas para a presença da construção gBlock + pGem-T Easy Vector.

Foi realizada a miniprep de seis colônias positivas e digestão com enzimas de restrição BshTI (AgeI) e SpeI (Thermo Scientific), para a confirmação da construção pGEMMAYV(E3E2V5) (Figura 13).

Figura 13 - Análise em gel de agarose 0,8\%. Confirmação da clonagem do vetor pGEMMAYV(E3E2V5) após transformação e amplificação em bactéria (Miniprep).

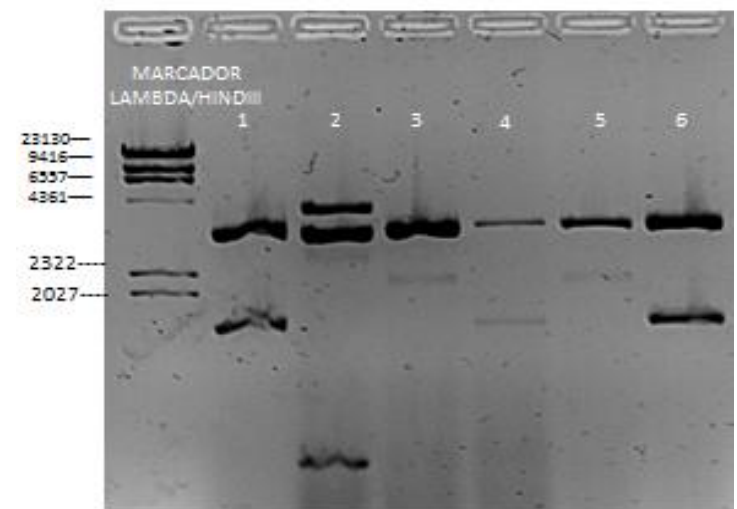

Análise em gel de agarose 0,8\% da digestão do vetor pGEMMAYV(E3E2V5) com enzimas SpeI e BshTI (AgeI). Nos poços numerados de 1 a 6 está representada a digestão de produtos de Miniprep: minipreps de colônias 1, 2 e 3 (poços 1, 2 e 3); minipreps de colônias 6, 7 e 8 (poços 4, 5 e 6). Fragmentos com tamanhos de $3000 \mathrm{bp}$ (referente ao vetor comercial pGEM-T Easy Vector) e 1617bp (fragmento Geneblock).

Duas colônias com correto padrão de digestão (1 e 6) foram utilizadas para amplificação do plasmídeo e purificação (Maxiprep). Para confirmação do plasmídeo obtido, foi realizada digestão enzimática com BshTI (AgeI) + SpeI (Figura 14A) ou ECORI + NotI ou somente com SpeI (Figura 14B). 
Figura 14 - Análise em gel de agarose 0,8\%. Confirmação da clonagem do vetor pGEMMAYV(E3E2V5) após purificação (Maxiprep).
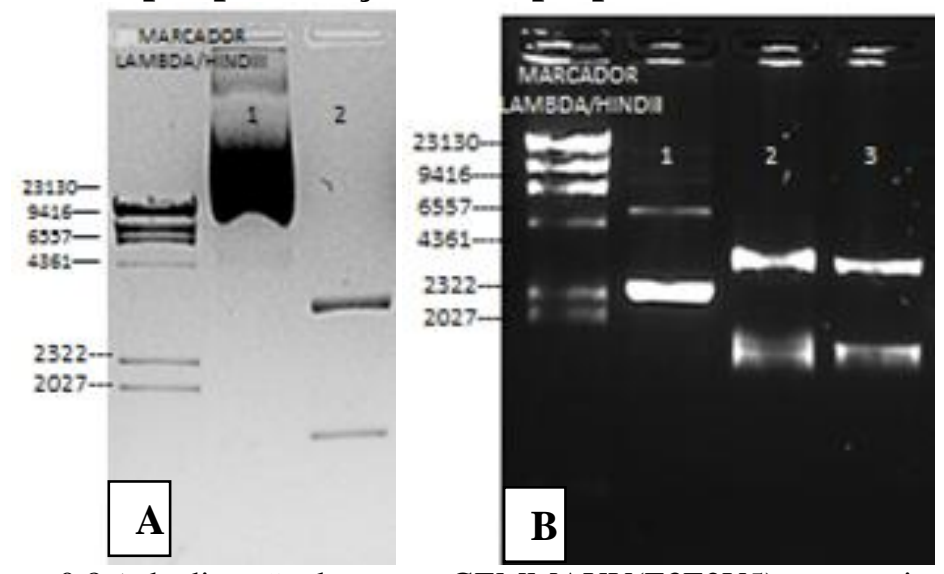

Análise em gel de agarose 0,8\% da digestão do vetor pGEMMAYV(E3E2V5) com enzimas BshTI (AgeI) / SpeI (A) ou com enzimas ECORI/NotI e SpeI (B). Confirmação da clonagem do vetor pGEMMAYV(E3E2V5), após Maxiprep, através de digestão por enzimas de restrição: em (A) 1 - pGEMMAYV(E3E2V5) colônia 1 circular; 2 - pGEMMAYV(E3E2V5) colônia 1 digerida com SpeI e BshTI (AgeI); em (B) 1 - pGEMMAYV(E3E2V5) circular; 2 - pGEMMAYV(E3E2V5) digerido com ECORI e NotI; 3 - pGEMMAYV(E3E2V5) digerido com SpeI.

O padrão de digestão do produto da maxiprep correspondeu ao esperado e o gene sintético (E3+E2+V5) pode ser observado na altura de, aproximadamente, 1600 bp após digestão enzimática com BshTI (AgeI) / SpeI ou somente com SpeI e 1521 bp quando usadas ECORI e NotI.

5.2 Obtenção dos vetores plasmidiais pMtMAYV(E3E2) e pMTBipMAYV(E3E2V5)

O inserto anteriormente clonado no vetor intermediário (pGEMMAYV(E3E2V5) 1 ) foi retirado utilizando as enzimas ECORI e NotI, sendo que as mesmas foram usadas para

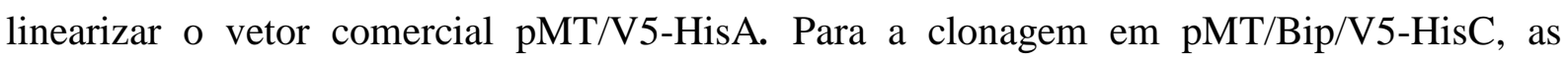
enzimas utilizadas para retirar o inserto foram NCOI e BshTI (AgeI). Os padrões de digestão observados após a corrida em gel de agarose 0,8\% corresponderam ao esperado (Figura 15). 
Figura 15 - Análise em gel de agarose 0,8\%. Digestão dos vetores pMT/V5-HisA e pMTBip/v5-HisC e retirada do inserto de pGEMMAYV(E3E2V5).
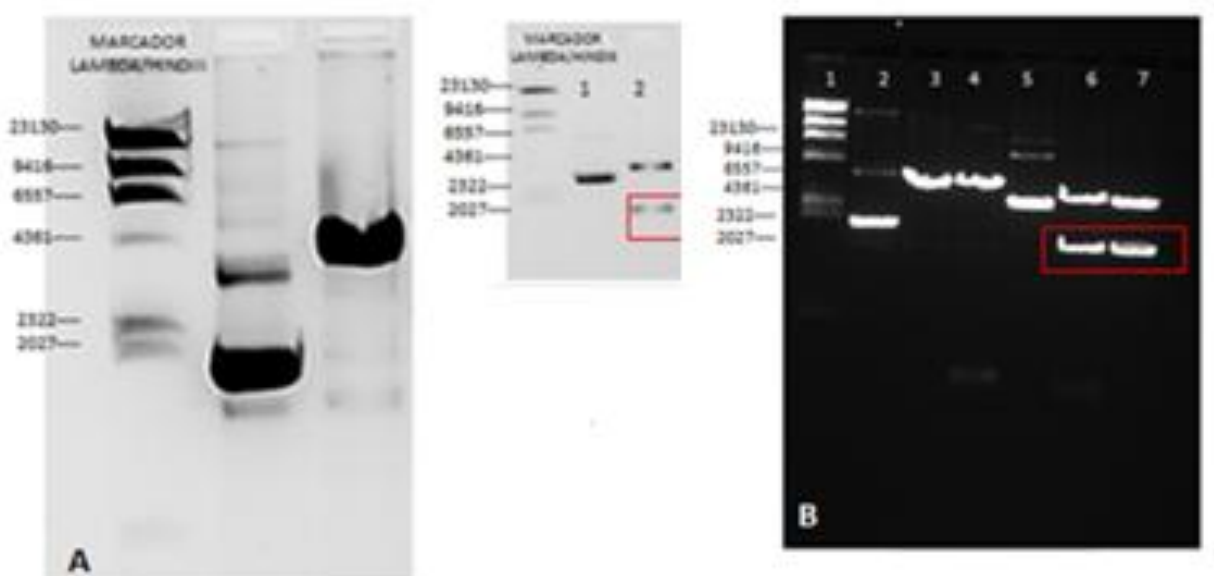

Gel de agarose 0,8\% mostrando os vetores comerciais: em (A) gel 1 - pMT/V5-HisA circular e linearizado com ECORI e NotI; gel 2 - pGEMMAYV(E3E2V5) circular e digerido com ECORI e NotI; (B) 1- marcador LAMBDA/HINDIII; 2 - pMTBip/V5-HisC circular; 3 - pMTBip/V5-HisC digerido com ECORI e NotI; 4 pMTBip/V5-HisC digerido com NCOI e AgeI; 5 - pGEMMAYV(E3E2V5) circular; 6 pGEMMAYV(E3E2V5) digerido com ECORI e NotI; 7 - pGEMMAYV(E3E2V5) digerido com NCOI e AgeI. Os fragmentos correspondentes ao inserto a ser inserido nos vetores comerciais aparecem em destaque nas imagens.

Para a clonagem em pMtBip/V5-HisC, priorizou-se os cortes com as enzimas NCOI e AgeI. Os produtos de digestão (vetores comerciais pMT/V5-HisA e pMTBip/V5-HisC linearizados e insertos retirados de pGEMMAYV (E3E2V5)) foram purificados diretamente do gel de agarose $0,8 \%$, ligados por enzima T4 DNA Ligase (Thermo Scientific ${ }^{\circledR}$ ) e transformados em bactérias. As colônias obtidas foram analisadas por PCR dirigido à proteína E2 para confirmar a clonagem do vetor pMTMAYV(E3E2V5) (Figura 16).

Figura 16 - PCR Convencional de colônias.

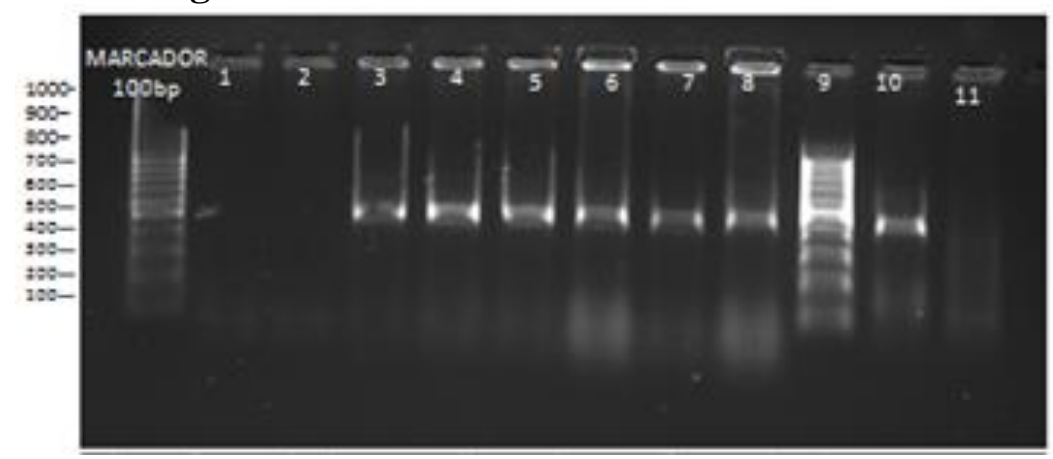

Análise em gel de agarose 1,5\% da PCR para confirmação das colônias obtidas após transformação bacteriana com a clonagem do vetor pMtMAYV(E3E2V5). Legenda: 1- e 2- controles negativos da reação contendo apenas os reagentes de PCR Convencional; 3 a 8 - colônias pMTMAYV(E3E2); 9 - marcador 100 bp; 10 - controle positivo (cDNA de células VERO infectadas com o vírus Mayaro); 11 - controle negativo (cDNA de células VERO não infectadas com o vírus Mayaro). As amostras positivas apresentaram amplificação de fragmento de 439 bp. 
Após a confirmação da presença do inserto em todas as colônias, realizou-se uma preparação plasmidial por lise alcalina (miniprep). Os produtos da miniprep de pMTMAYV(E3E2V5) e o vetor comercial pMT/V5-HisA sem inserto foram digeridos com as enzimas de restrição ECORI / NotI e PvuII para confirmação da construção (Figura 17).

\section{Figura 17 - Confirmação da clonagem do vetor pMTMAYV(E3E2V5) por padrão de digestão com enzimas de restrição.}

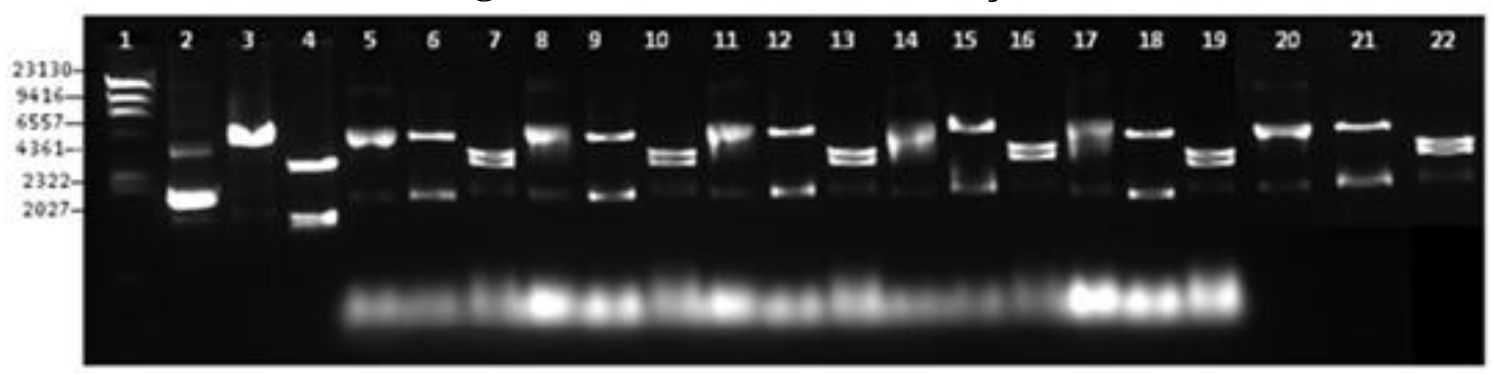

Análise em gel de agarose $0,8 \%$ do vetor comercial pMT/V5-HisA e os produtos de miniprep da clonagem pMTMAYV(E3E2V5) digeridos com enzimas de restrição ECORI / NotI e PvulI. Legenda: 1 - marcador LAMBDA/HINDIII; 2 - pMt/V5-HisA circular; 3 - pMt/V5-HisA digerido com ECORI/NotI; 4 - pMt/V5-HisA doigeridocom PvuII; 5, 8, 11, 14, 17, 20 - pMtMAYV(E3E2) circular; 6, 9, 12, 15, 18, 21 - pMtMAYV(E3E2) digerido com ECORI/NotI ; 7, 10, 13, 16, 19, 22 - pMtMAYV(E3E2) digerido com PvuII.

Todas as colônias apresentaram o correto padrão de bandas para a construção, a saber: 3511 bp/1521 bp após corte com enzimas ECORI / NotI e 2669 bp/2363 bp com PvuII, sendo escolhida a clonagem número 4 para a realização da extração do DNA plasmidial (Maxiprep). Para confirmação do produto de maxiprep, novas digestões com enzimas ECORI / NotI e PvuII foram realizadas e o padrão de bandas, quando comparado ao vetor comercial sem inserto (pMT/V5-HisA), seguiu o esperado para a clonagem (Figura 18). 
Figura 18 - Confirmação da clonagem do vetor pMTMAYV(E3E2V5) após purificação (Maxiprep).

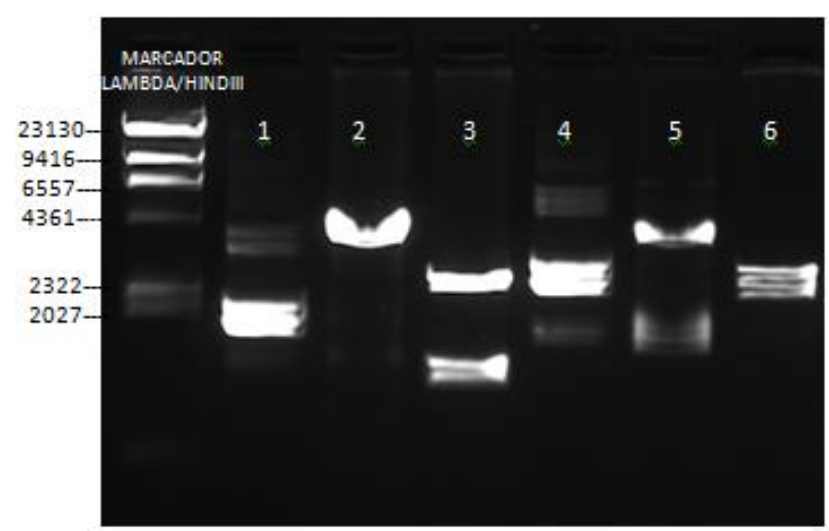

Análise em gel de agarose $0,8 \%$ do vetor comercial pMT/V5-HisA e os produtos de maxiprep da clonagem pMTMAYV(E3E2V5) digeridos com enzimas de restrição ECORI / NotI e PvuII. Legenda: 1 - pMt/V5-HisA circular; 2 - pMt/V5-HisA digerido com ECORI/NotI; 3 - pMt/V5-HisA digerido com PvuII; 4 pMtMAYV(E3E2) circular; 5 - pMtMAYV(E3E2) digerido com ECORI/NotI; 6 - pMtMAYV(E3E2) digerido com PvuII.

Da mesma forma que seguiu-se o protocolo de clonagem do plasmídeo pMTMAYV(E3E2), bactérias quimiocompetentes foram transformadas com a ligação pMTBipMAYV(E3E2V5) e uma PCR convencional foi realizada para confirmar a presença do inserto (Figura 19).

\section{Figura 19 - PCR Convencional de colônias para identificação dos clones positivos para a construção do vetor pMtBipMAYV(E3E2).}

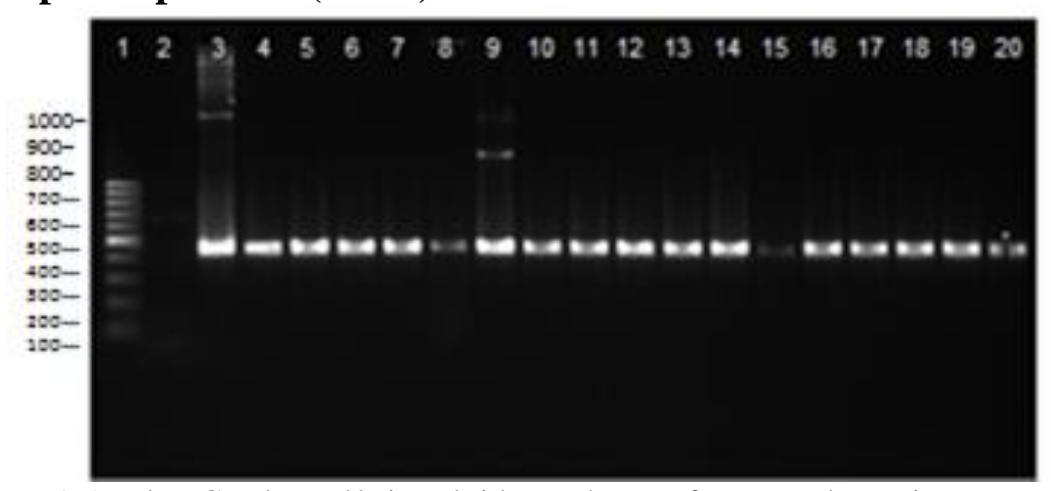

Análise em gel de agarose 1,5\% da PCR das colônias obtidas após transformação bacteriana com a clonagem do vetor pMTBipMAYV(E3E2V5). Legenda: 1 - Marcador 100 bp; 2 - controle negativo contendo apenas os reagentes da PCR Convencional; 3 - controle positivo (clonagem pGEMMAYV(E3E2V5)); 4 a 20- colônias pMtBipMAYV(E3E2V5). As amostras positivas apresentaram amplificação de fragmento de $439 \mathrm{bp}$.

Após a confirmação da presença do inserto em todas as colônias, realizou-se a miniprep das amostras 2 (condição de ligação 2:1) e 4 (condição de ligação 3:1). Porém, após estudo do mapa do vetor pMTBipMAYV(E3E2V5), foi observado que o corte inicial com as enzimas de restrição NCOI/AgeI gerou um stop codon antes da proteína E3 do gene sintético, pois nesse caso o início da transcrição se dá na sequência sinal da proteína Bip, upstream ao 
inserto clonado no vetor. Uma nova digestão enzimática dos produtos de miniprep com BgLII, promovendo a retirada de 61 nucleotídeos presentes entre o vetor e a proteína E3, e posterior religação com T4 DNA Ligase foram necessárias para a retirada desse stop codon, possibilitando a transcrição correta dos genes de interesse.

Após a digestão com Bgl II, purificação do plasmídeo a partir do gel e religação com T4 DNA ligase, o plasmídeo obtido foi utilizado para transformação bacteriana. Preparações plasmidiais foram purificadas a partir das colônias obtidas e posteriormente digeridas com enzima BamH I (Fermentas). O padrão de digestão apresentando fragmentos de 3335bp, 1518bp e 207bp corresponde ao esperado para o plasmídeo pMTBipMAYV(E3E2V5) (Figura 20).

Figura 20 - Análise em gel de agarose 0,8 \%. Confirmação da clonagem do vetor pMtBipMAYV(E3E2V5) após purificação (Miniprep).

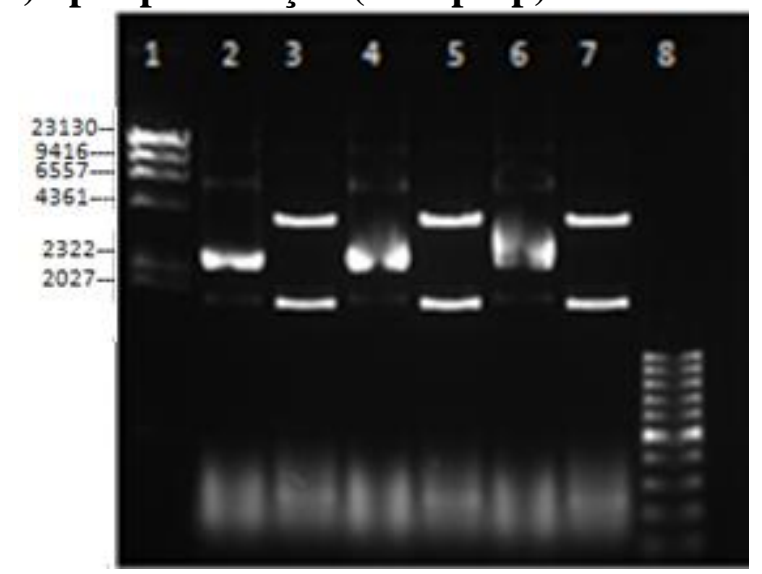

Análise em gel de agarose $0,8 \%$ do vetor pMtBipMAYV(E3E2V5) na forma circular (A) e digerido com enzima BamHI (B). Legenda: 1 - Marcador LAMDA/HINDIII; 2, 4 e 6 - produtos de miniprep circulares; 3, 5, 7 produtos de miniprep digeridos com BamHI; 8 - marcador $100 \mathrm{bp}$.

O produto de miniprep 2 foi escolhido pois apresentou, exclusivamente, os tamanhos de bandas referentes à digestão com a enzima BamHI. Essa colônia foi então crescida para amplificação do plasmídeo que, após purificação (Maxiprep) foi confirmado por digestão com enzimas BamHI e PvuII. Foi obtido o padrão de digestão esperado, ou seja, os fragmentos de 2697bp e 2363bp após corte com enzima PvuII e 3335 bp, 1518 bp e 207 bp para BamHI (Figura 21). 
Figura 21 - Análise em gel de agarose 0,8 \%. Confirmação da construção do vetor pMtBipMAYV(E3E2V5) após purificação (Maxiprep).

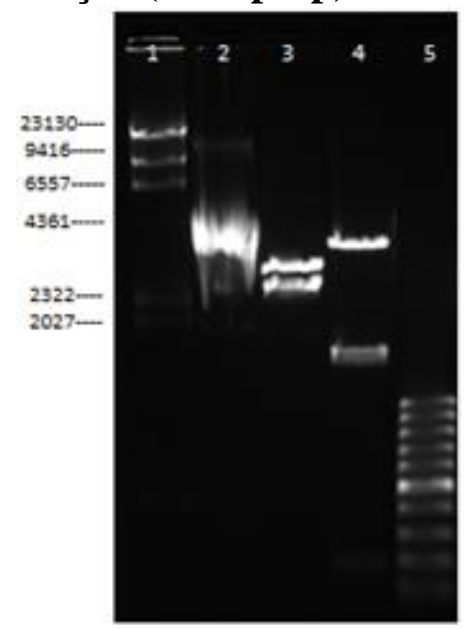

Análise em gel de agarose $0,8 \%$ da digestão do vetor pMtBipMAYV(E3E2V5) com enzimas PvuII e BamHI. Legenda: 1 - Marcador LAMBDA/HINDIII; 2 - pMtBipMAYV(E3E2V5) circular; 3 pMtBipMAYV(E3E2V5) digerido com PvuII; 4 - pMtBipMAYV(E3E2V5) digerido com BamHI; 5 - marcador $100 \mathrm{bp}$.

Para a confirmação da retirada do fragmento de 61 nucleotídeos após digestão enzimática com BgLII, outras duas digestões foram realizadas com as enzimas ClaI e SpeI, as quais perderiam seus sítios de restrição após a digestão com BgLII e o vetor genético continuaria na forma circular, ao contrário do que aconteceria caso a digestão com esta não tivesse sido eficiente, gerando um plasmídeo linearizado (Figura 22). A figura mostra que as enzimas Cla I e Spe I não foram capazes de digerir o plasmídeo após a digestão com Bgl II, confirmando a retirada do fragmento de 61 nucleotídeos e portanto do stop codon.

Figura 22 - Análise em gel de agarose 0,8\%. Confirmação da retirada do fragmento de 61 nucleotídeos após digestão enzimática com BglII.

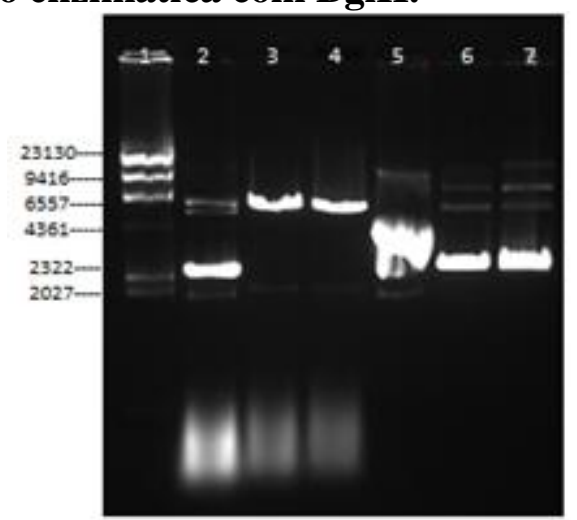

Análise em gel de agarose $0,8 \%$ da digestão de pMtBipMAYV(E3E2V5), com e sem corte prévio por enzima BgLII, após digestão enzimática por ClaI e SpeI. Legenda: 1 - marcador LAMBDA/HINDIII; 2 pMtBipMAYV(E3E2V5) circular; $3-$ pMtBipMAYV(E3E2V5) digerido com ClaI; $4 \quad-$ pMtBipMAYV(E3E2V5) digerido com SpeI; 5 - pMtBipMAYV(E3E2V5) religado após digestão com BgLII; 6 - pMtBipMAYV(E3E2V5) religado e digerido com ClaI; 7 - pMtBipMAYV(E3E2V5) religado e digerido com SpeI. 
Os plasmídeos foram enviados para sequenciamento na faculdade de Medicina Veterinária da Universidade de São Paulo, confirmando a correta clonagem dos fragmentos.

\subsection{Estabelecimento das populações celulares}

As preparações plasmidiais obtidas, pMtMAYV(E3E2) e pMtBipMAYV(E3E2), foram utilizadas para a transfecção de células $S 2$, resultando na obtenção das populações S2MtMAYV(E3E2) e S2MtBipMAYV(E3E2). Essas populações celulares posteriormente passaram por três processos de enriquecimento distintos, conforme o descrito nas seções $4.2 \mathrm{e}$ 4.3, para a obtenção de linhagens com maiores níveis e proporção de células expressando a proteína E2 de MAYV. Isso resultou no estabelecimento de cinco linhagens ao longo do desenvolvimento do trabalho (Tabela 5), de forma que os resultados obtidos por imunofluorescência indireta são apresentados conforme as linhagens celulares encontravamse disponíveis após os processos de enriquecimento e seleção.

Tabela 5 - Linhagens de células $\mathbf{S 2}$ recombinantes estabelecidas para a expressão da glicoproteína E2 do vírus Mayaro.

\begin{tabular}{|l|l|l|}
\hline \multicolumn{1}{|c|}{ Linhagem de origem } & \multicolumn{1}{|c|}{$\begin{array}{c}\text { Método de } \\
\text { enriquecimento/seleção }\end{array}$} & $\begin{array}{c}\text { Linhagem estabelecida e } \\
\text { utilizada nos experimentos }\end{array}$ \\
\hline S2MtMAYV(E3E2) & $\begin{array}{l}\text { Pressão seletiva adicional } \\
\text { com Higromicina B por 15 } \\
\text { dias após o estabelecimento } \\
\text { da linhagem original. }\end{array}$ & S2MtMAYV(E3E2) \\
\hline S2MtMAYV(E3E2) & $\begin{array}{l}\text { Seleção imunomagnética } \\
\text { (MACs) com anticorpo } \\
\text { hiperimune de } \\
\text { camundongos anti-MAYV } \\
\text { (ATCC). }\end{array}$ & S2MtMAYV(E3E2)_M1 \\
\hline S2MtMAYV(E3E2) & $\begin{array}{l}\text { Seleção clonal pelo método } \\
\text { desenvolvido utilizando } \\
\text { feeder cells de S2 selvagem } \\
\text { tratadas com Mitomicina } \\
\text { C. }\end{array}$ & S2MtMAYV(E3E2)_SC \\
\hline S2MtBipMAYV(E3E2V5) & $\begin{array}{l}\text { Pressão seletiva adicional } \\
\text { com Higromicina B por 15 } \\
\text { dias após o estabelecimento } \\
\text { da linhagem original. }\end{array}$ & S2MtBipMAYV(E3E2V5) \\
\hline S2MtBipMAYV(E3E2V5) & $\begin{array}{l}\text { Seleção clonal pelo método } \\
\text { desenvolvido utilizando } \\
\text { feeder cells de S2 selvagem } \\
\text { tratadas com Mitomicina } \\
\text { C. }\end{array}$ & \\
\hline
\end{tabular}




\subsection{Padronização da técnica de Imunofluorescência Indireta}

O processo de padronização do protocolo de Imunofluorescência Indireta (IFI) com células recombinantes de Drosophila melanogaster (S2) foi realizado primeiramente com células S2 expressando a Glicoproteína do Vírus da Raiva (RVGP). Essa abordagem foi realizada pois a glicoproteína E2 de MAYV também se trata de uma proteína de membrana e a célula utilizada é a mesma. Uma vez obtidos bons resultados com suporte antigênico de S2 recombinante expressando RVGP, o protocolo passou a ser utilizado para as células S2MtMAYV(E3E2), S2MtBipMAYV(E3E2V5) e demais sub-linhagens quando disponíveis.

A padronização se baseou na avaliação de alguns parâmetros: 1-) melhor condição na qual as células foram fixadas em lamínulas de forma que as etapas de lavagem não as eliminassem; 2-) melhor condição de análise qualitativa (nitidez da amostra, homogeneidade dos campos, preservação das características das células) e 3-) intensidade de marcação da proteína RVGP. Primeiramente, foi testada a fixação de células em lamínulas com solução de Metanol/Acetona 1:1 durante 20 minutos em temperatura ambiente e os resultados obtidos estão representados na figura 23. Em seguida, foi testado FORMALDEÍDO a 4\% e 2\% nas mesmas condições (Figura 24). Tais soluções de fixação já são amplamente utilizadas em diversos estudos (AMARAL, 2010; MARANGONI, et al., 2000; MENDONÇA; DOLCI, 2005; SAIJO, et al., 2002).

Figura 23 - Teste de fixação com solução de Metanol/Acetona 1:1.

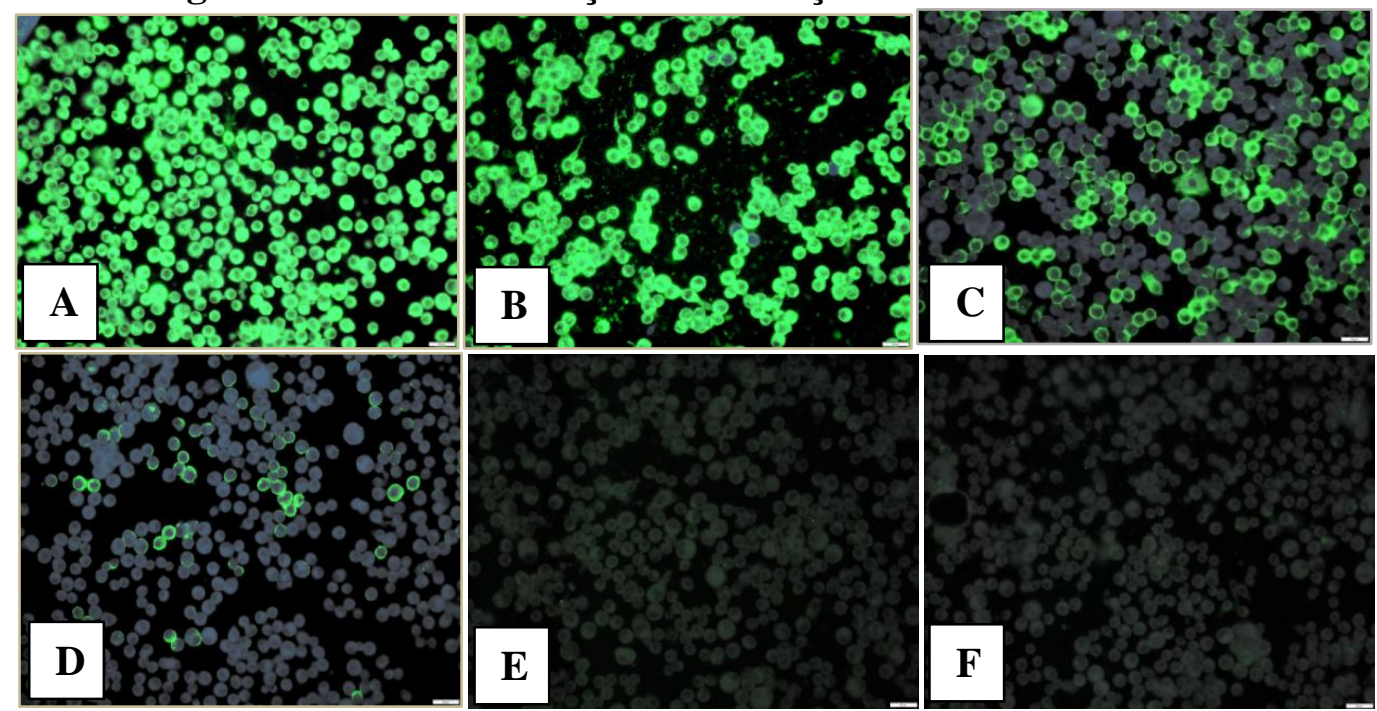

Células S2MtRVGPHy-M3 foram cultivadas em lamínulas e a expressão induzida com $\mathrm{CuSO}_{4}$ durante 24 horas. Para a realização da imunofluorescência foi testada a fixação com solução Metanol/Acetona 1:1 e diferentes marcações: soro de coelho anti-vacina (A); soro de camundongo anti-vacina (B); anticorpo primário C75 de camundongo (C); anticorpo primário M-D1-100 de camundongo (D); marcação com soro de coelho imunizado com salina $(\mathbf{E})$; soro de camundongo imunizado com salina $(\mathbf{F})$. Aumento de $400 \mathrm{X}$. 
Como pode ser observado nas imagens acima, a fixação com solução de Metanol/Acetona 1:1 foi eficiente para o propósito estabelecido de preservar as características morfológicas das células para a melhor detecção da proteína de membrana, aliado à nitidez de imagem. Porém, para garantir que esta seria a mais adequada solução de fixação celular em lamínulas, também foram testados formaldeído $2 \%$ e $4 \%$ e os resultados representados abaixo (Figura 24).

\section{Figura 24 - Teste de fixação com solução de formaldeído a $2 \%$ e a $4 \%$.}

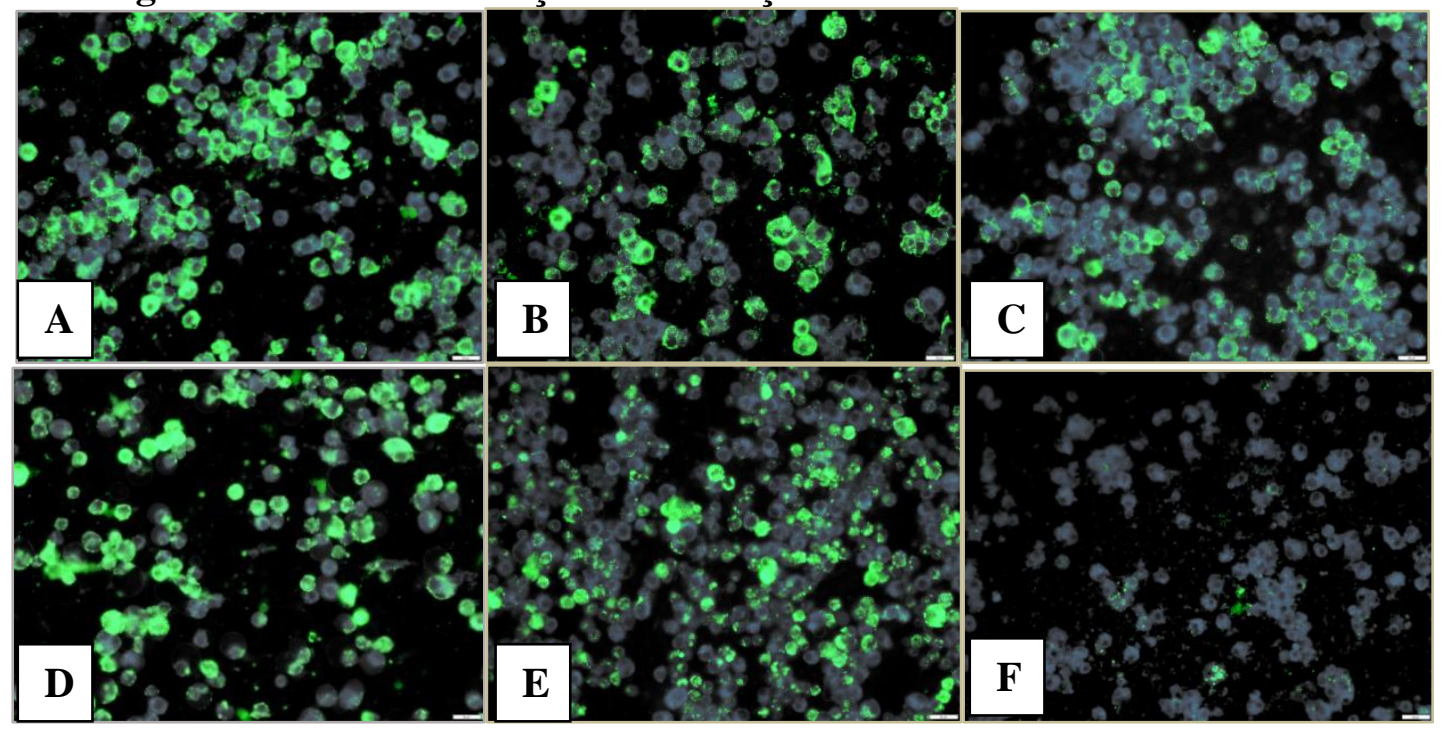

Células S2MtRVGPHy-M3 foram cultivadas em lamínulas e a expressão induzida com $\mathrm{CuSO}_{4}$ durante 24 horas. Para a realização da imunofluorescência foram testados: fixação com solução formaldeído $4 \%$ e marcação com soro de coelho anti-vacina de raiva (A); fixação com solução formaldeído $4 \%$ e marcação com soro de camundongo anti-vacina (B); fixada com formaldeído $4 \%$ por 20 minutos e marcada com anticorpo monoclonal de camundongo M-D1-100 (C); fixação com paraformaldeido a 2\% e marcação com soro de coelho anti-vacina de raiva (D); fixação com formaldeído $2 \%$ e marcação com anticorpo monoclonal de camundongo C75 (E); fixada utilizando-se solução de formaldeído a $2 \%$ por 20 minutos e marcada com soro de camundongo imunizado com salina (F). Aumento de $400 \mathrm{X}$.

A fixação com formaldeído a 4\% e 2\% (Figura 24), em geral, não foi eficiente como com Metanol/Acetona 1:1 (Figura 23), pois as células eram perdidas durante o processo de lavagem após a incubação com o anticorpo secundário, além da perda de qualidade de nitidez e de morfologia das células fotografadas. Quando foi utilizada a solução de Metanol/Acetona $1: 1$, a perda celular foi notoriamente menor. É evidente também a diferença entre a qualidade de imagem oferecida dependendo do método de fixação utilizado e tal característica deve ser um fator de grande importância no estabelecimento do melhor protocolo de imunofluorescência indireta, pois interfere diretamente na qualidade do resultado obtido. $\mathrm{O}$ tempo de fixação de 20 minutos se mostrou adequado para a preservação da membrana celular, de modo a permitir a marcação da RVGP presente na membrana. 
Na tentativa de melhorar a aderência das células às lamínulas, foi testada a fixação com a solução Metanol/Acetona 1:1, que apresentou os melhores resultados, em temperatura de $-20{ }^{\circ} \mathrm{C}$ pelo mesmo tempo (20 minutos), sendo obtidos resultados ainda mais satisfatórios (Figura 25).

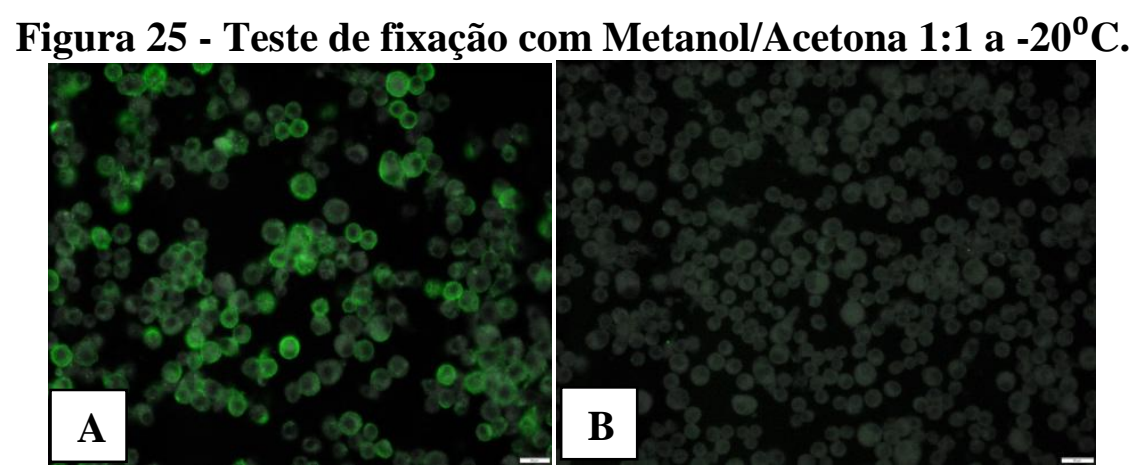

Células S2MtRVGPHy-M3 foram cultivadas em lamínulas e a expressão induzida com $\mathrm{CuSO}_{4}$ durante 24 horas. Para a realização da imunofluorescência as células foram fixadas com solução Metanol/Acetona 1:1por 20 minutos a $-20{ }^{\circ} \mathrm{C}$ e marcadas com: soro de coelho imunizado com vacina contra raiva (A); soro de coelho imunizado com salina (B). Aumento de $400 \mathrm{X}$.

Ao contrário da fixação com formaldeído (Figura 24), em que pôde ser observada uma alteração na característica morfológica das células, a fixação com a solução metanol/acetona $1: 1$ por 20 minutos a $-20{ }^{\circ} \mathrm{C}$ manteve as células em concentração adequada por campo, além de preservar a estrutura das mesmas, indicando um bom método de fixação (Figura 25).

Os resultados obtidos levaram à conclusão de que o teste padronizado estava adequado para a utilização não apenas com anticorpos monoclonais, mas também com amostras de soros, o que era fundamental para o objetivo central proposto neste trabalho.

Também foi realizado um teste para verificar a melhor forma de armazenamento das lamínulas contendo células S2 apenas induzidas e fixadas com solução Metanol/Acetona 1:1 para posterior marcação com anticorpos primário e secundário. As temperaturas testadas foram de $-20{ }^{\circ} \mathrm{C}$ e $-80{ }^{\circ} \mathrm{C}$ por 3 meses. Após esse período, as células foram marcadas com anticorpo primário $\mathrm{C} 75$ e, posteriormente, anti-IgG de camundongos conjugado a FITC. A análise em microscópio de fluorescência mostrou que à temperatura de $-20{ }^{\circ} \mathrm{C}$ a proteína de membrana ainda estava na conformação ideal pois foi possível seu reconhecimento pelos anticorpos e a estrutura morfológica das células se encontrava íntegra e preservada, permitindo boa visualização da marcação na membrana celular (dado não representado).

No total foram realizadas aproximadamente 100 análises de imunofluorescência para o estabelecimento do procedimento de imunofluorescência indireta padronizado para células S2 
cultivadas sobre lamínulas (ANEXO I). Em síntese, o procedimento foi testado nas diferentes condições de fixação citadas no Quadro 1 (item 4.4.5), mostrando os melhores resultados quando utilizada a solução Metanol/Acetona 1:1 por 20 minutos à temperatura de $-20{ }^{\circ} \mathrm{C}$, tempo suficiente para a aderência das células e preservação das suas estruturas. Uma segunda padronização do procedimento de imunofluorescência foi realizada utilizando as populações celulares recombinantes S2MtMAYV(E3E2) e S2MtBipMAYV(E3E2V5) que haviam sido recentemente obtidas. Esta padronização foi realizada baseando-se na utilização de menores quantidades de anticorpos e maior tempo de cultivo na presença do agente indutor de expressão (ANEXO II).

Os resultados da utilização desse procedimento para a marcação de células expressando a proteina E2 possibilitou a detecção da mesma de forma eficiente (Figura 26), sem ligação inespecífica a antígenos de superfície naturais da população selvagem (Figura 26A). Essa segunda padronização foi favorável, permitindo a obtenção de imagens com boa relação nitidez/número de células por campo visual, além de possibilitar a utilização de apenas $40 \mu \mathrm{L}$ de anticorpos diluídos.

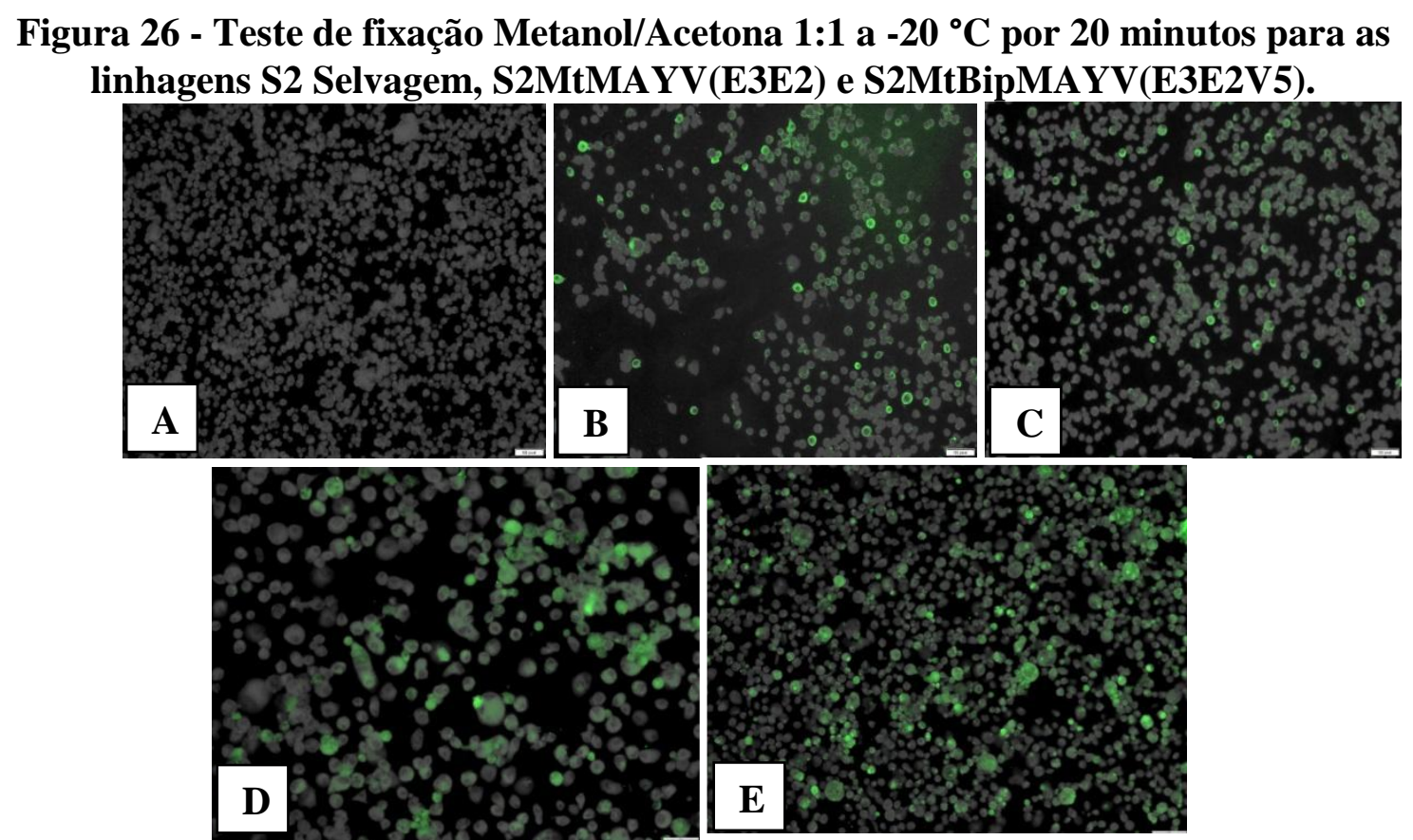

Células S2 Selvagens, S2MtMAYV(E3E2) e S2MtBipMAYV(E3E2V5) foram cutivadas em garrafas T25 e a expressão induzida com $\mathrm{CuSO}_{4}$ durante 144 horas. Para a realização da imunofluorescência foi utilizada a solução de fixação Metanol/Acetona 1:1 e a marcação com soro hiperimune de camundongo imunizado com o vírus Mayaror: S2 Selvagem (A); S2MtMAYV(E3E2 (B) e (C); S2MtMAYV(E3E2) (D); S2MtBipMAYV(E3E2V5) (E). Anticorpos secundários anti-IgG de camundongos (1:750). Aumentos de $200 \mathrm{X}$ e $400 \mathrm{X}$. 
5.4.1 Método de imunofluorescência indireta aplicado à detecção de anticorpos anti-Mayaro em amostras de soro de camundongos

Após a obtenção dos resultados satisfatórios na detecção da proteína E2 de membrana em células $S 2$ recombinantes originais (S2MtMAYV(E3E2) e S2MtBipMAYV(E3E2V5)) e o estabelecimento das linhagens (S2MtMAYV(E3E2)_M1, S2MtMAYV(E3E2)_SC e S2MtBipMAYV(E3E2V5)_SC), o protocolo de imunofluorescência indireta pôde ser aplicado para verificar qual processo de seleção, dentre os utilizados, permitiu a melhor expressão da glicoproteina de interesse. Para isso, os tempos de 144 e 168 horas pós-indução foram analisados e a marcação de E2 foi realizada utilizando como anticorpo primário o Soro Hiperimune de camundongo anti-MAYV (ATCC). A verificação de ausência de ligação inespecífica foi realizada a partir da marcação das linhagens recombinantes originais com soro de camundongo não-imune (ATCC). A Figura 27 abaixo mostra o resultados obtidos para as linhagens S2MtMAYV(E3E2), S2MtBipMAYV(E3E2V5), S2MtMAYV(E3E2)_M1, S2MtMAYV(E3E2)_SC e S2MtBipMAYV(E3E2V5)_SC.

Como pode ser observado, as linhagens obtidas após o processo de seleção clonal apresentaram uma melhor detecção da proteína E2 na membrana celular quando comparadas às linhagens originais S2MtMAYV(E3E2) e S2MtBipMAYV(E3E2V5). A linhagem S2MtMAYV(E3E2)_SC, em especial, mostrou maior intensidade de fluorescência por célula, embora a relação de número de células marcadas por campo visual não tenha apresentado diferença significativa quando comparada a S2MtBipMAYV(E3E2V5)_SC. Por esse motivo, S2MtMAYV(E3E2)_SC foi utilizada posteriormente para os testes com amostras de soro humano positivas para infecção pelo vírus Mayaro. Os tempos de 144 e 168 horas pósindução com $\mathrm{CuSO}_{4}$ mostraram igual relação de expressão de E2/célula em todas as linhagens. Ao contrário do esperado, a linhagem S2MtMAYV(E3E2)_M1 não apresentou maior expressão da glicoproteína quando comparada à original, indicando que o método de seleção imunomagnética não foi o ideal para o propósito pretendido.

Os tempos de 72, 96 e 120 horas pós-indução foram analisados para todas as linhagens, porém não apresentaram nenhuma ou quase indetectável expressão da proteína de interesse. Por esta razão, as figuras não foram incluídas. 
Figura 27 - Linhagens de células S2 recombinantes marcadas com soro não-imune e hiperimune anti-MAYV de camundongos nos tempos 144 e 168 horas pós-indução.
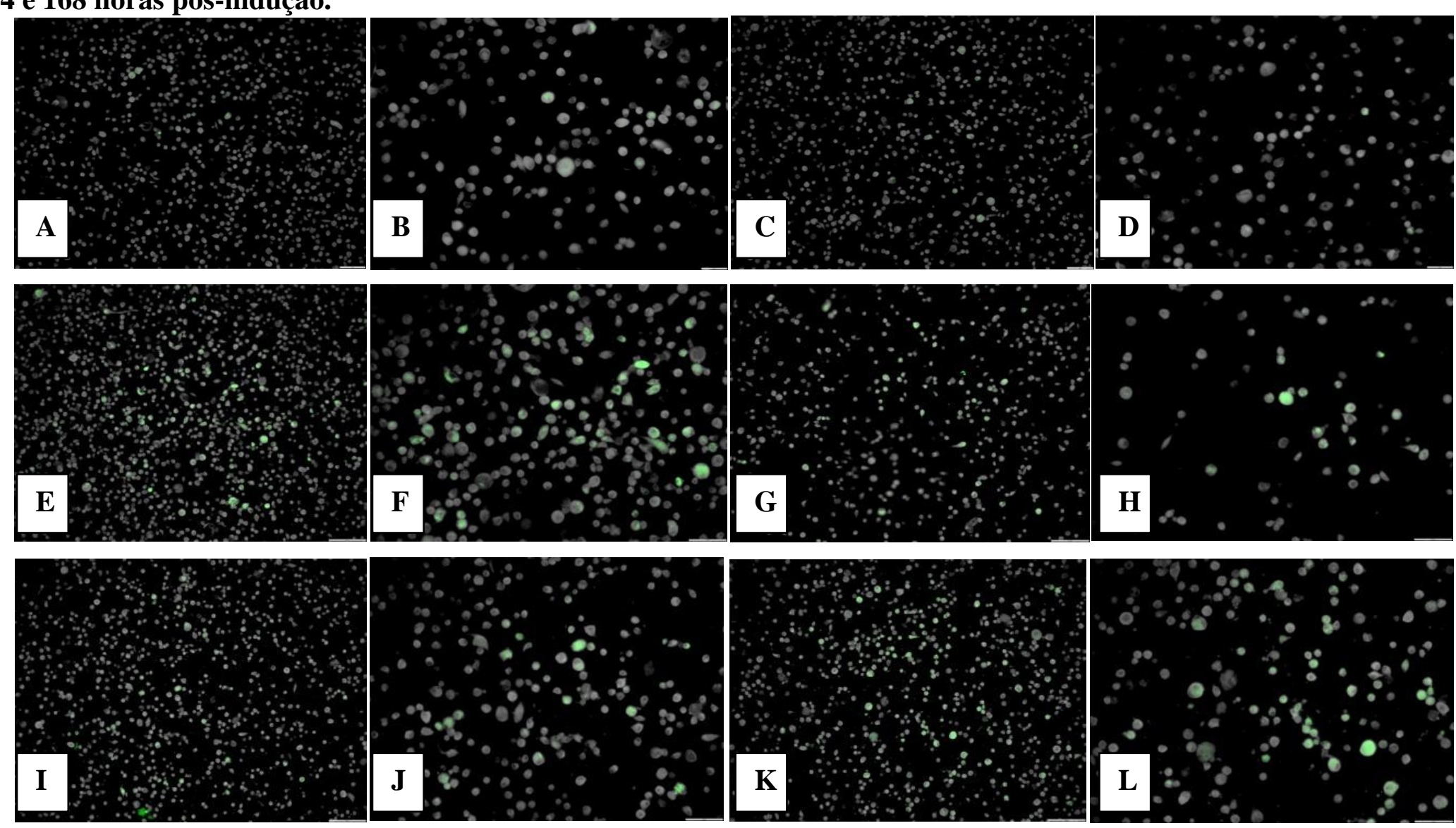

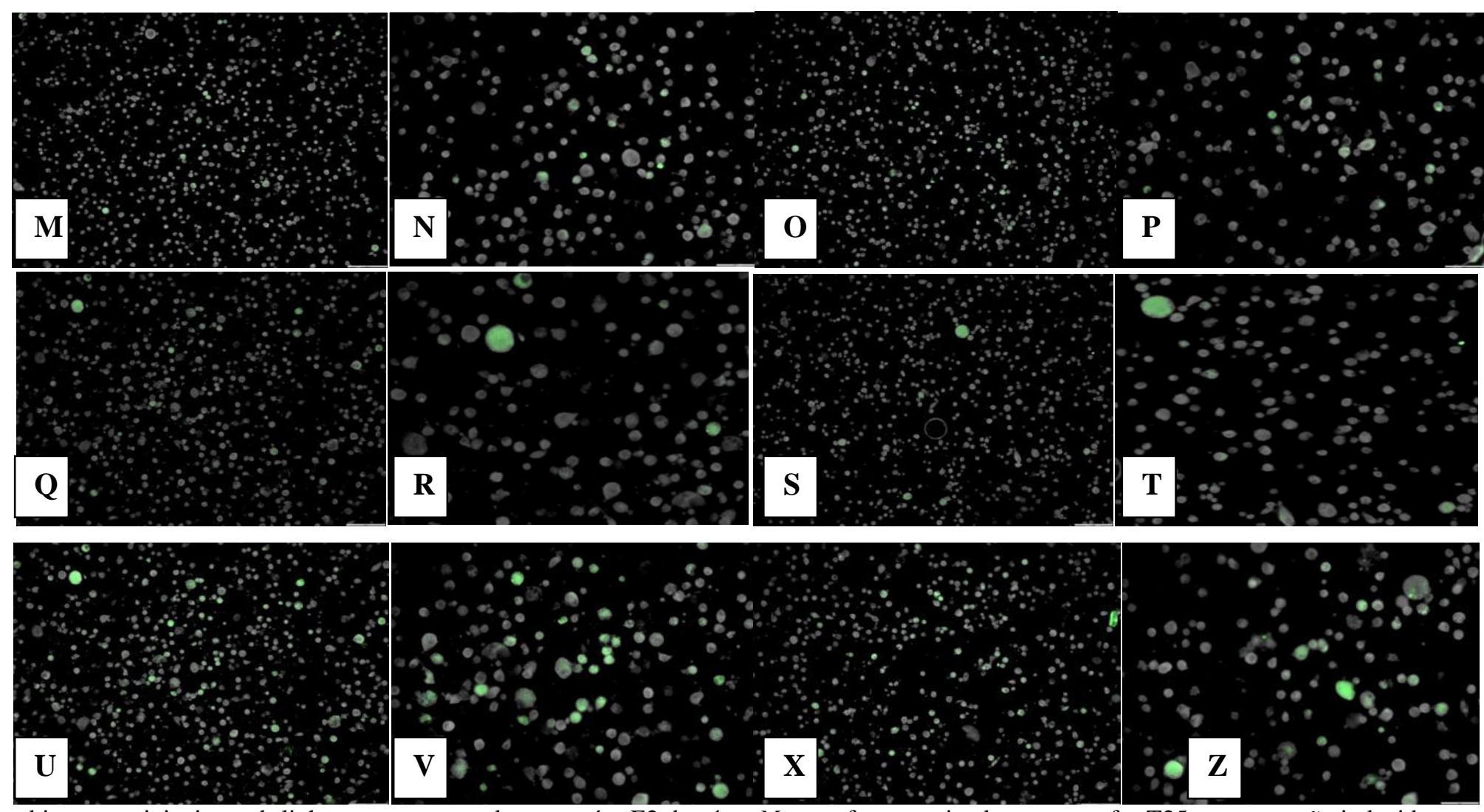

Células S2 recombinantes originais e sub-linhagens expressando a proteína E2 do vírus Mayaro foram cutivadas em garrafas T25 e a expressão induzida com CuSO 4 durante 144 e 168 horas. A fixação foi realizada com solução Metanol/Acetona $1: 1$ (-20 ${ }^{\circ} \mathrm{C}$ durante 20 minutos) e marcação com soro não-imune de camundongo (1:500): S2MtBipMAYV(E3E2V5) induzida 144 horas (A) e (B); S2MtMAYV(E3E2) induzida 144 horas (C) e (D). Marcação com soro hiperimune de camundongo anti-MAYV (1:500): S2MtBipMAYV(E3E2V5) induzida 144 horas (E) e (F) ou 168 horas (G) e (H); S2MtMAYV(E3E2) induzida 144 horas (I) e (J) ou 168 horas (K) e (L); S2MtMAYV(E3E2) M1 induzida 144 horas $(\mathbf{M})$ e $(\mathbf{N})$ ou 168 horas $(\mathbf{O})$ e $(\mathbf{P})$; S2MtBipMAYV(E3E2V5) SC induzida 144 horas $(\mathbf{Q})$ e $(\mathbf{R})$ ou 168 horas $(\mathbf{S})$ e $(\mathbf{T})$; S2MtMAYV(E3E2)_SC induzida 144 horas (U) e (V) ou 168 horas (X) e (Z). Anticorpos secundários anti-IgG de camundongos FITC (1:750). Aumento de 200 X e 400 X. 
5.4.2 Método de Imunofluorescência Indireta aplicado à detecção de anticorpos anti-Mayaro, Chikungunya, Dengue e Zika em amostras de soro humano

Para a linhagem S2MtMAYV(E3E2)_SC foram testados os tempos 144 e/ou 168 horas pós-indução na presença de soros de pacientes positivos para os arbovírus de principal importância clínica atualmente (Zika, Dengue e Chikungunya) e o de particular interesse nesse estudo, o vírus Mayaro. Para os vírus Chikungunya e Zika, as amostras de soro disponíveis eram de fase aguda; para Dengue fase covalescente e Mayaro fases aguda e covalescente (Figura 28).

Os resultados permitiram concluir que os tempos de 144 e 168 horas apresentaram o mesmo nível de expressão proteica/célula e mesma intensidade de fluorescência quando da utilização de amostras de soro humano positivas para MAYV e CHIKV, indicando que ambos são suficientes para o correto e eficiente folding da glicoproteina E2 de membrana (Figura 28 I - X). A partir dessas conclusões parciais, outras duas amostras de soro humano de fase aguda positivas para o vírus Mayaro e uma também de fase aguda para Chikungunya foram incubadas com a linhagem S2MtMAYV(E3E2)_SC induzida pelo tempo de 144 horas e detectadas com anticorpos anti-IgM humano para confirmar a utilidade desse suporte de antígeno como método diagnóstico. Foram obtidos resultados satisfatórios, com boa relação de expressão de proteína/célula (Figura 29 A - F).

Portanto, utilizando as células S2MtMAYV(E3E2)_SC como suporte antigênico para a glicoproteina E2 de MAYV, foi possível detectar anticorpos humanos do tipo IgM em amostras de soro de indivíduos em fase aguda para infecção por Mayaro ou Chikungunya, bem como anticorpos IgG em indivíduos em fase convalescente para Mayaro. 
Figura 28 - Linhagem S2MtMAYV(E3E2)_SC incubada com soros humanos negativo e positivos para os arbovírus Mayaro, Chikungunya, Dengue e Zika e anticorpos secundários anti-IgM e IgG humano FITC.

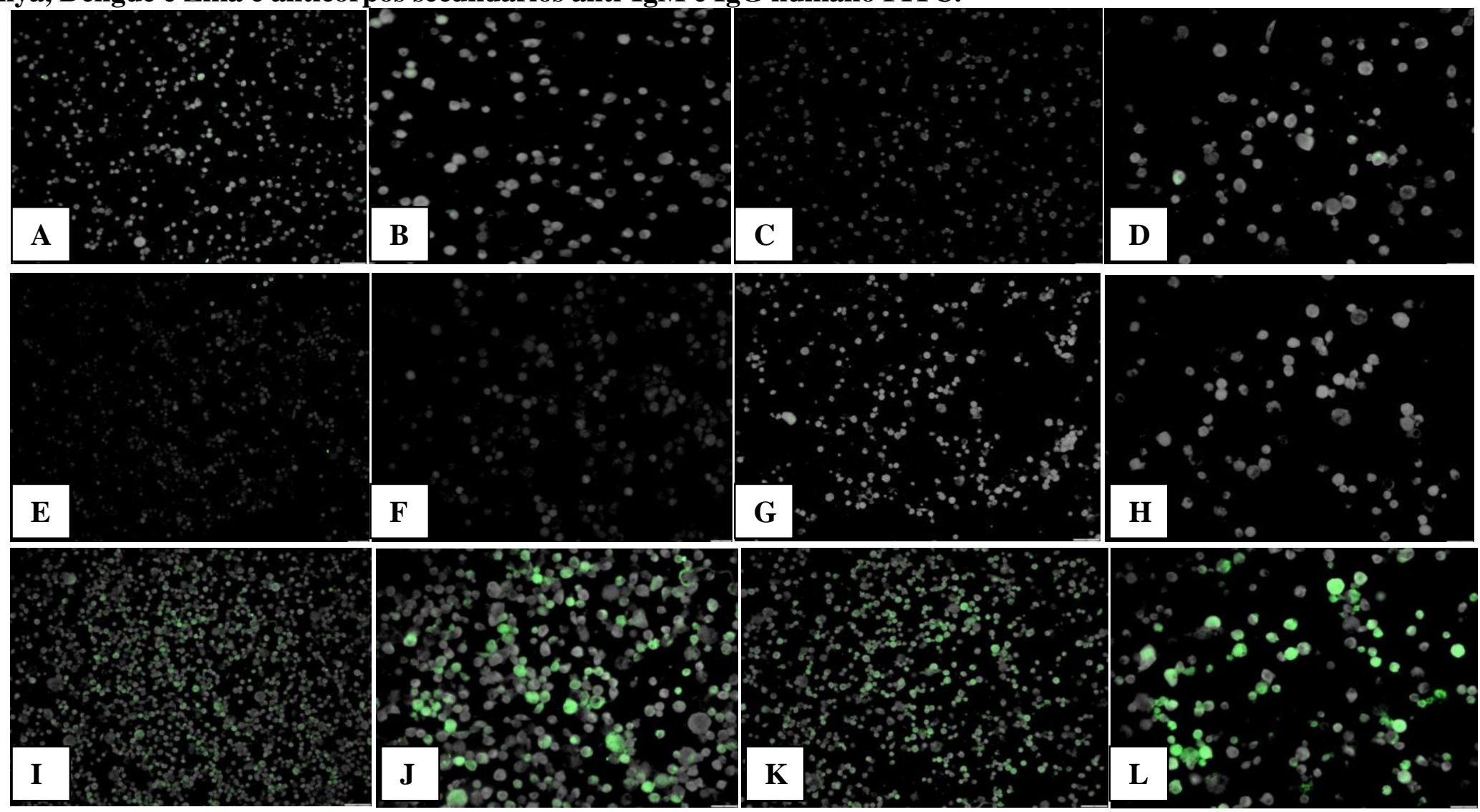



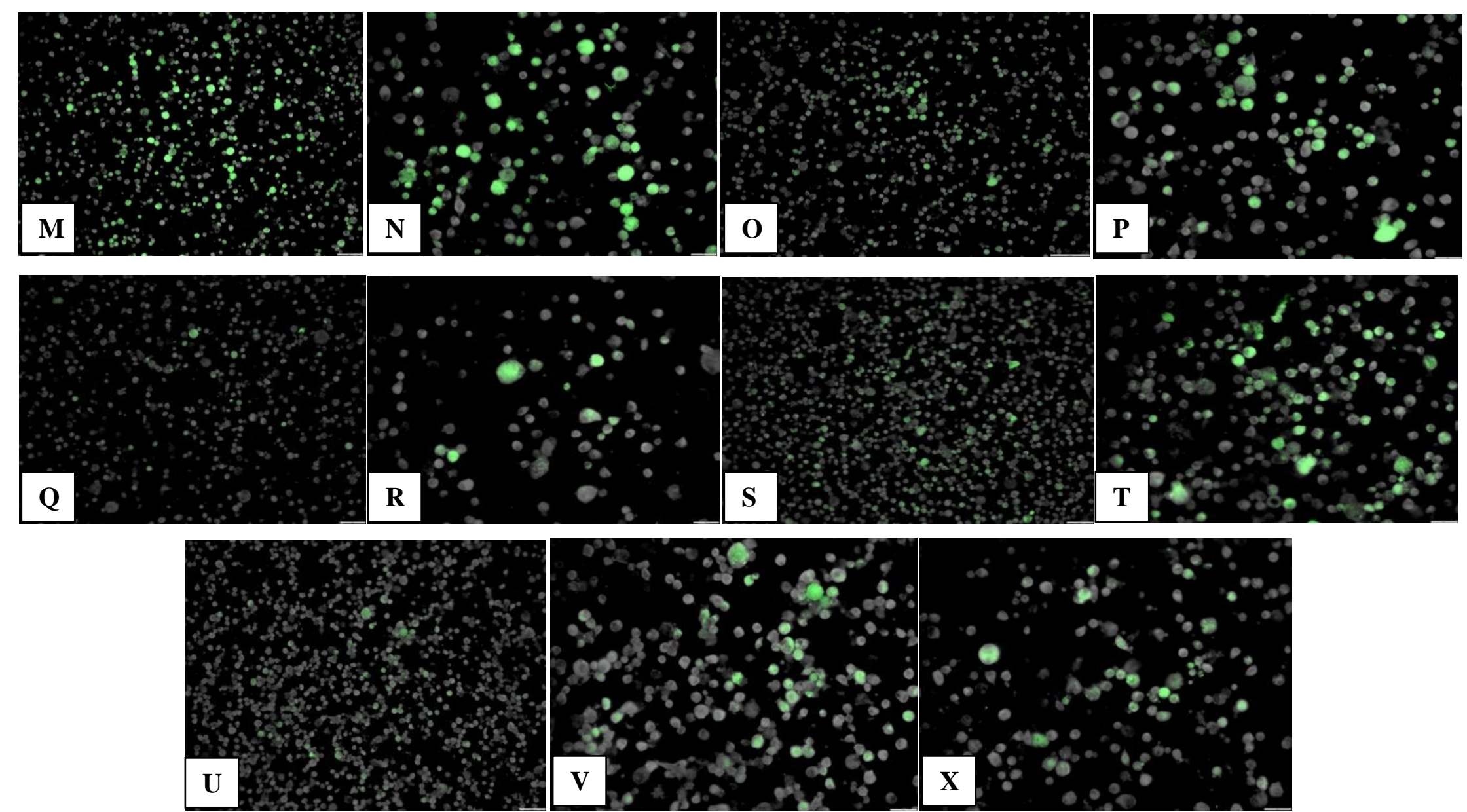

Células S2MtMAYV(E3E2)_SC foram cultivadas em garrafas T25 e a expressão induzida com CuSO durante 144 e/ou 168 horas. A fixação foi realizada com solução Metanol/Acetona 1:1. Amostras de soro humano e tempo de indução das células utilizadas: Soro negativo para Alphavirus em células induzidas por 144 horas (A) e (B) ou 168 horas $(\mathbf{C})$ e $(\mathbf{D})$. Soro de fase convalescente para Dengue em células induzidas por 144 horas $(\mathbf{E})$ e $(\mathbf{F})$. Soro de fase aguda para ZIKA, em células induzidas por 144 horas (G) e (H). Soro de fase aguda para Mayaro, em células induzidas por 144 horas $(\mathbf{I})$ e (J) ou 168 horas $(\mathbf{K})$ e (L). Soro de fase covalescente para Mayaro, em células induzidas por 144 horas $(\mathbf{M})$ e $(\mathbf{N})$ ou 168 horas $(\mathbf{O})$ e $(\mathbf{P})$. Soro de fase aguda Chikungunya (amostra de soro 1), em células induzidas por 144 horas $(\mathbf{Q})$ e $(\mathbf{R})$ ou 168 horas $(\mathbf{S})$ e $(\mathbf{T})$; (amostra de soro 2): em células induzidas por 144 horas $(\mathbf{U})$ e $(\mathbf{V})$ ou 168 horas $(\mathbf{X})$. Anticorpos secundários anti-IgM e IgG humano FITC (1:1500). Aumentos de 200X e $400 X$. 
Figura 29 - Linhagem S2MtMAYV(E3E2)_SC incubada com amostras de soro humano de fase aguda para infecção pelos arbovírus Mayaro ou Chikungunya e anticorpo secundário anti-IgM humano FITC.
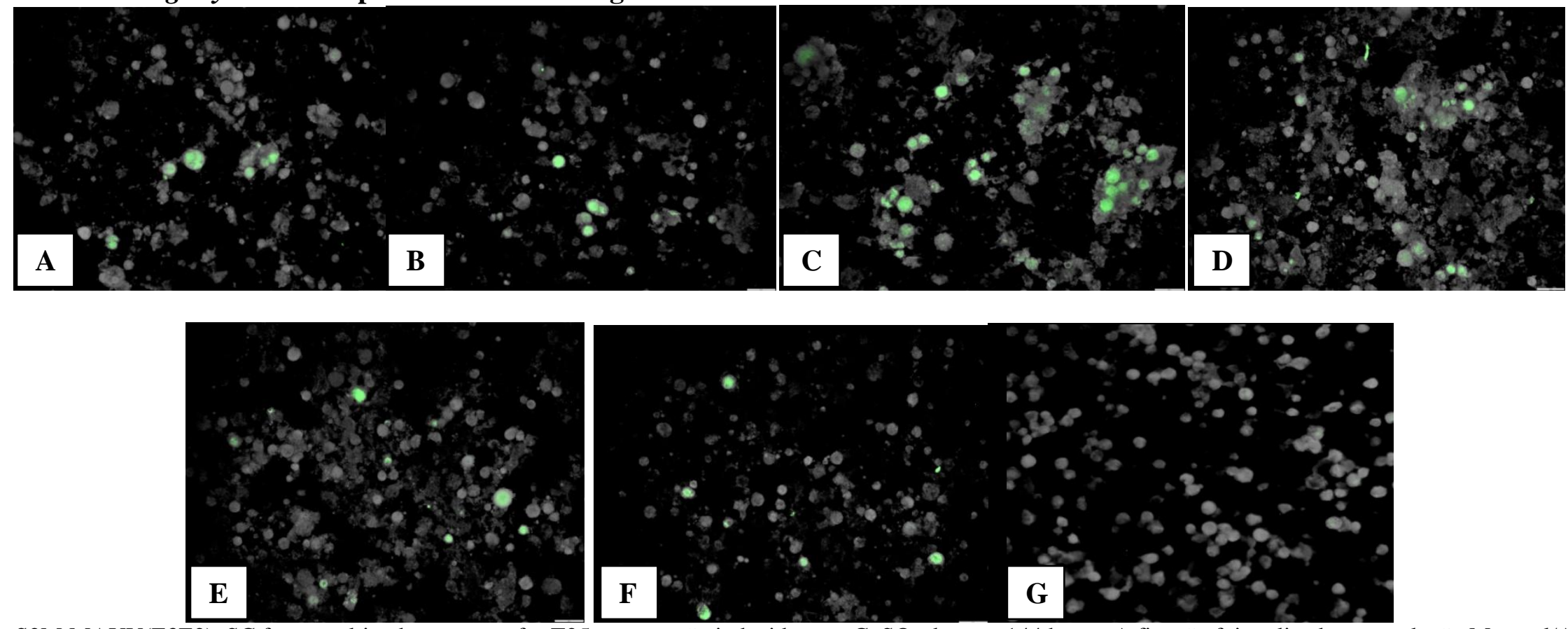

Células S2MtMAYV(E3E2)_SC foram cultivadas em garrafas T25 e expressão induzida com CuSO 4 durante 144 horas. A fixação foi realizada com solução Metanol/Acetona 1:1. Incubação: Soro humano de fase aguda para Mayaro, amostra de soro 2 (A) e (B); amostra de soro 3 (C) e (D); Soro humano de fase aguda para Chikungunya: amostra de soro 3 (E) e (F); Soro humano negativo para Alphavirus (G). Anticorpos secundários anti-IgM humano FITC (1:1500). Aumento de 400 X. 
Para verificar a positividade do soro humano contra Zika, de maneira a corroborar as conclusões anteriores sobre a distinção eficaz entre a presença de anticorpos anti-Alphavirus ou anti-Flavivirus, o soro de Zika foi testado em células VERO infectadas com o vírus Zika no Laboratório de Imunologia Viral (Figura 30). O protocolo de IFI para células VERO foi o mesmo aplicado para a linhagem S2, com modificação apenas na etapa de fixação, em que foi utilizado formaldeído $4 \%$, que permite a preservação da morfologia celular.

Figura 30 - Teste de imunofluorescência para verificação de positividade do soro humano anti-Zika.
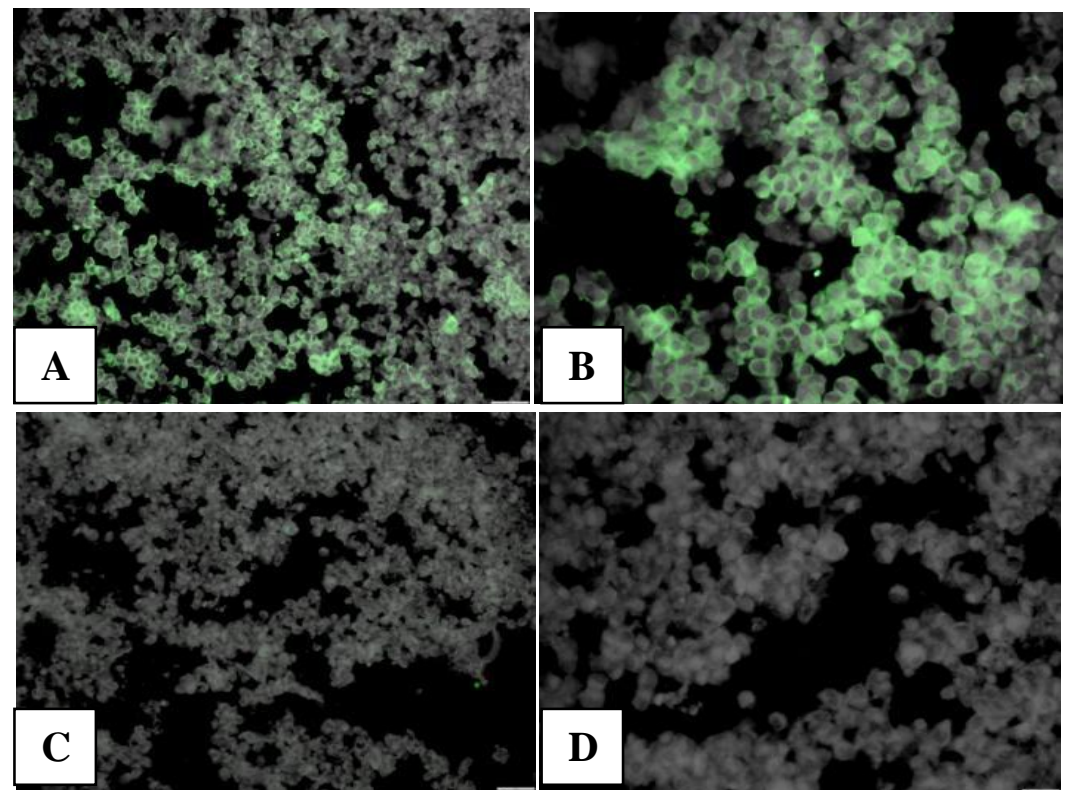

Células VERO foram cultivadas em garrafas T25 e infectadas com vírus Zika MOI 0,02 durante 96 horas. A fixação foi realizada com formaldeído $4 \%$ e incubada com soros humanos de fase aguda de infecção pelo vírus Zika (A) e (B) ou negativo para Zika (C) e (D). Anticorpos secundários anti-IgG humano FITC (1:1500). Aumentos de $200 \mathrm{X}$ e $400 \mathrm{X}$.

Para verificar se o teste de imunofluorescência indireta permite a detecção de marcação na membrana celular a partir de diluição de amostra de soro de pacientes, a critério de comparação com o método diagnóstico EIA-ICC, que detecta positividade empregando uma diluição do soro positivo para Mayaro de até 1:8000 (FIGUEIREDO et al., 1989), foram realizadas diluições de 1:1000, 1:2000, 1:3000, 1:4000, 1:5000, 1:6000, 1:7000 e 1:8000 para uma amostra de soro humano de fase aguda e uma de fase covalescente para infecção por MAYV. Na figura 31 estão representadas as diluições de 1:1000 e 1:8000 de ambas as amostras, mostrando a diferença de marcação e permitindo verificar a eficácia do teste. 
FIGURA 31 - Teste de diluição de amostras de soro humano de fases aguda e covalescente para infecção pelo vírus Mayaro.
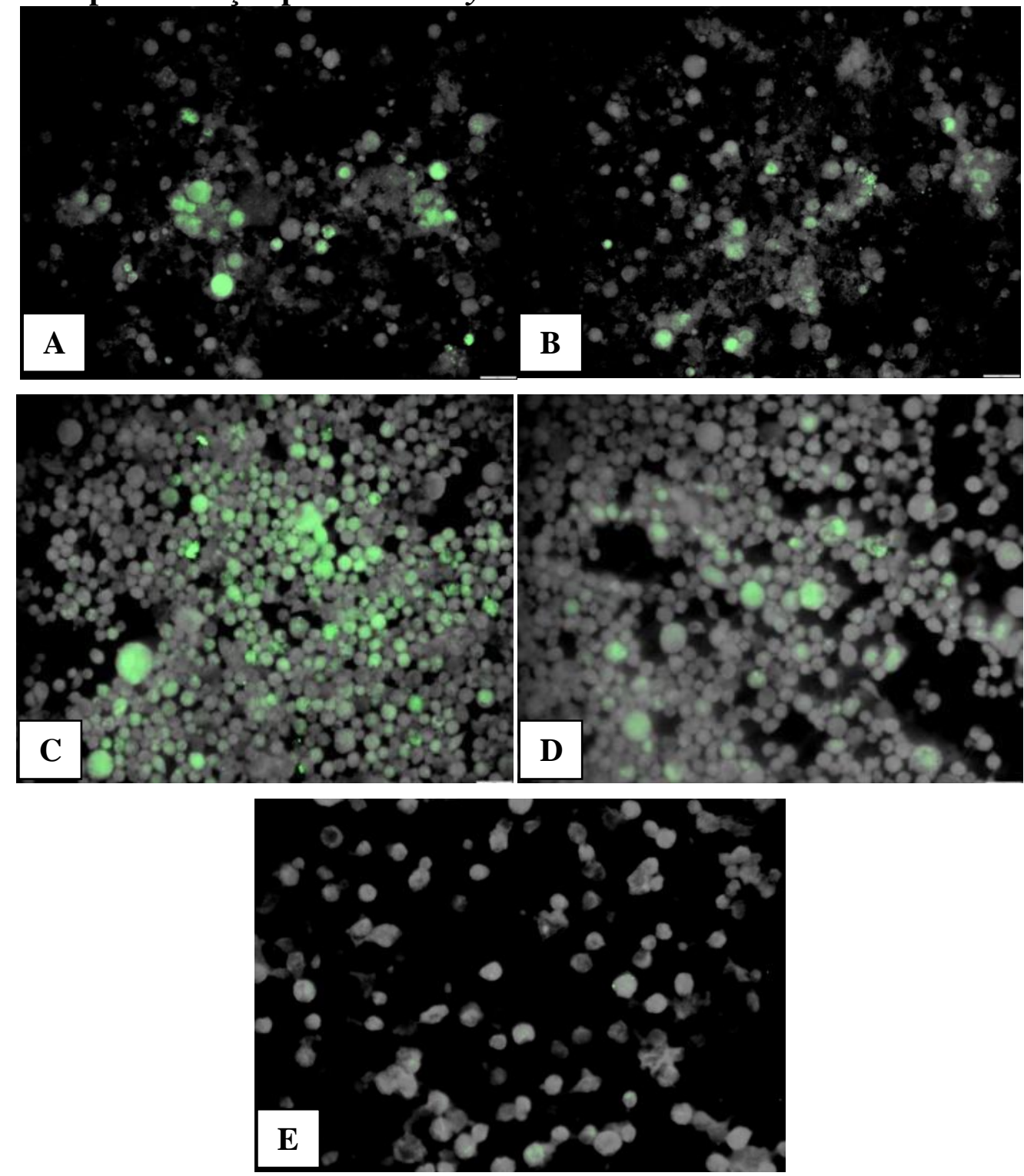

Células S2MtMAYV(E3E2)_SC foram cultivadas em garrafas T25 e a expressão induzida com $\mathrm{CuSO}_{4}$ durante 144 horas. A fixação foi realizada com solução Metanol/Acetona 1:1 e a incubação com soro humano de fase aguda para Mayaro nas seguintes diluições: 1:1000 (A); 1:8000 (B). Incubação com soro humano de fase covalescente para Mayaro: 1:1000 (C); 1:8000 (D). Incubação com soro humano negativo para Alphavirus 1:500 (E). Anticorpos secundários anti-IgM (A e B) e anti-IgG humano (C e D) FITC (1:1500). Aumento de 400 X.

A análise dos resultados obtidos apontou que a técnica de imunofluorescência indireta utilizando o suporte recombinante pode responder de forma eficiente ao objetivo proposto de obter um método alternativo para o diagnóstico diferencial entre Alphavirus/Flavivirus. 
A análise das cinéticas de crescimento das linhagens celulares S2 Selvagem, S2MtMAYV(E3E2), S2MtBipMAYV(E3E2V5), S2MtMAYV(E3E2)_M1, S2MtMAYV(E3E2)_SC e S2MtBipMAYV(E3E2V5)_SC mostrou um perfil de crescimento celular similar até os tempos referentes a 96 e 120 horas após a indução, alcançando concentrações na ordem de $10^{7}$ células/mL, esperadas para células S2 recombinantes (Figura 32).

Figura 32 - Cinética de crescimento de células S2 selvagem e recombinantes na presença de $\mathrm{CuSO}_{4}$.

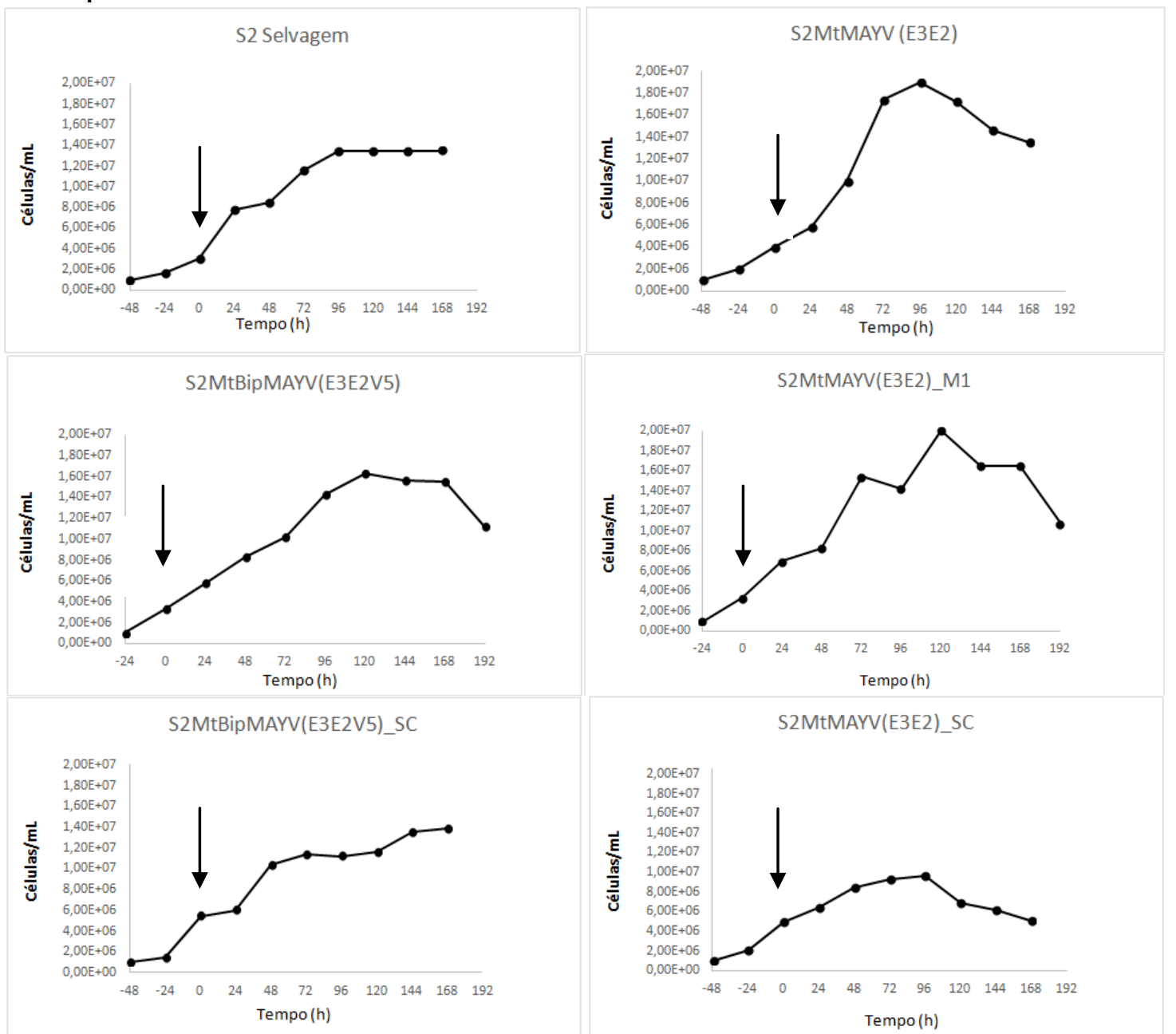

Para o estudo da cinética de crescimento e a viabilidade celular após a indução da expressão, foram retiradas amostras diariamente e a viabilidade medida pelo método de azul de Trypan. As culturas foram induzidas quando a concentração celular atingiu o intervalo entre 3,0 e 5,0 × $10^{6}$ células $/ \mathrm{mL}$, conforme os protocolos padronizados do laboratório para células $\mathrm{S} 2$ recombinantes. A escala de tempo indica o tempo $0 \mathrm{~h}$ marcando o momento da indução com $\mathrm{CuSO}_{4}(\downarrow)$, já que algumas células apresentaram fase lag e tardaram mais para atingir $\mathrm{o}$ intervalo apropriado para a indução 
A partir do intervalo entre 96 e 120 horas de indução, as linhagens recombinantes que receberam o vetor pMtMAYV(E3E2) apresentaram declínio na concentração celular, ao passo que as culturas de $\mathrm{S} 2$ selvagem $\mathrm{e}$ as recombinantes que receberam $\mathrm{o}$ vetor pMTBitMAYV(E3E2) mantiveram a quantidade de células viáveis até o tempo máximo de 168 horas pós-indução (Figura 32).

5.6 Quantificação relativa do mRNA da Glicoproteína E2 de MAYV nas linhagens de células $S 2$ recombinantes estabelecidas

Como forma de verificar indiretamente o perfil de expressão da glicoproteína E2 de MAYV, foram medidas as quantidades relativas de mRNA entre os tempos de 72 horas e 168 horas após a indução da expressão, pois entre 24 e 48 horas não há expressão significativa da glicoproteína E2 na membrana das células, conforme observado por imunofluorescência indireta previamente (dados não incluídos). Os resultados mostraram que o tempo de 72 horas de indução com $\mathrm{CuSO}_{4}$ apresentou as maiores quantidades de RNA relativo à glicoproteína E2 do vírus Mayaro. Na maioria das linhagens celulares, a quantidade de RNA relativo da E2 decresceu ou estabilizou conforme o tempo de pós-indução aumentou (Gráfico 2). Dessa forma, os tempos em que as quantidades de RNA relativo são menores coincidem com os tempos em que a glicoproteína E2 foi detectada de maneira mais evidente por imunofluorescência. A quantificação relativa de mRNA a partir de 72 horas permitiu verificar um perfil de expressão do mRNA da proteína E2, semelhante ao encontrado em trabalhos prévios realizados para a análise da expressão do mRNA da glicoproteína do vírus da raiva (RVGP) em células S2, em que há uma queda na abundância do transcrito justamente no momento em que se inicia o intervalo de maior expressão recombinante (ASTRAY et al., 2013; SANTOS et al., 2016). Os dados para a subpopulação S2MtBipMAYV(E3E2)_SC não foram apresentados pois não houve rendimento de RNA total durante a extração por kit. 
Gráfico 2 - mRNA relativo à glicoproteína $\mathrm{E} 2$ do vírus Mayaro nas linhagens de células $\mathrm{S} 2$ recombinantes em diferentes tempos de indução com $\mathrm{CuSO}_{4}$.

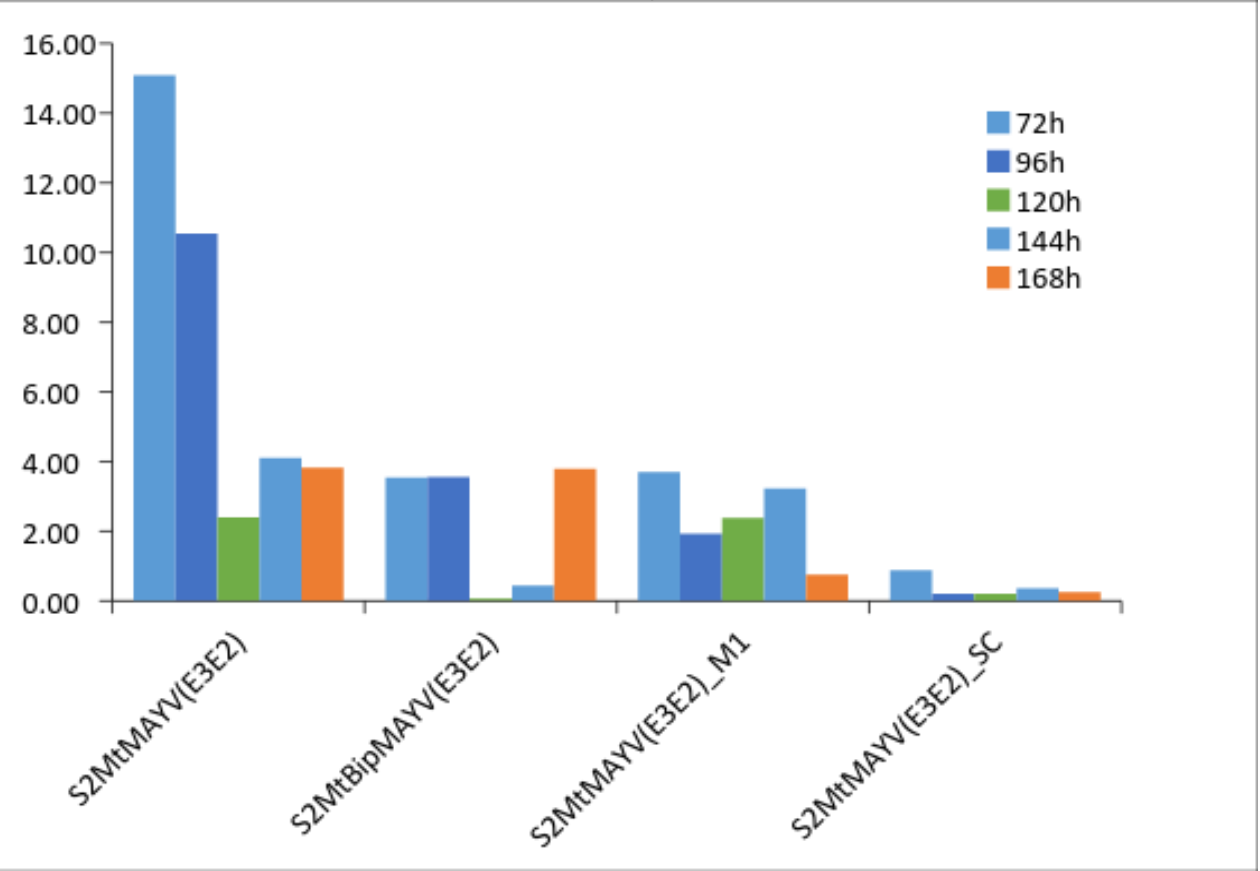

Análise por RT-qPCR da quantidade de mRNA da glicoproteína E2 de MAYV relativa ao calibrador escolhido (amostra de S2MtMAYV(E3E2)_SC, tempo 72h após a indução). As subpopulações foram cultivadas em triplicatas, sendo separadas para análise as amostras de dois Schotts nos tempos especificados na legenda. As amostras de cada shott em cada tempo foram analisadas em triplicatas e a média dos Cts obtida foi utilizada nos cálculos da quantidade relativa de RNA. 


\section{DISCUSSÃO}

A ocorrência das doenças febris agudas causadas por arbovírus como Zika, Dengue, Chikungunya tem sido hoje um alerta para a possibilidade de novos surtos de Febre Amarela e para a transmissão urbana de outra arbovirose, muito similar à causada por CHIKV, a chamada Febre Mayaro, pois todos esses apresentam vetores em comum. Além disso, reforçam a necessidade de vigilância epidemiológica do vírus Mayaro, sua semelhança com a doença causada pelo vírus Chikungunya, e a evidência de que este vírus já pode estar sendo transmitido em perímetro urbano, devido à sua capacidade de infectar espécies urbanas de mosquitos, como Aedes e Culex, possibilidade que já havia sido demonstrada laboratorialmente há alguns anos atrás (ACADEMIA BRASILEIRA DE CIÊNCIAS, 2010; LONG et al., 2011; MARCONDES; XIMENES, 2015; SERRA et al., 2016; ZUCHI et al., 2014). Em vista desta realidade, diversos estudos têm sido realizados a fim de desenvolver um melhor método diagnóstico no que se refere à sensibilidade e especificidade, priorizando a detecção de IgM na fase aguda da enfermidade, como a técnica de EIA-ICC (FIGUEIREDO et al., 1989). Esse teste, porém, apresenta problemas de sensibilidade devido à presença de muito ruído de fundo (background), pois trata-se de um ELISA realizado sobre um tapete de células infectadas como matriz sensibilizada. Necessita ainda da manipulação constante do vírus Mayaro selvagem, o que, traz preocupações do ponto de vista da biossegurança. Por esta razão, foi proposto realizar neste trabalho a padronização de um método de imunofluorescência indireta baseado na expressão recombinante da principal proteína imunogênica de MAYV, a glicoproteína E2. O teste foi idealizado e padronizado buscando reunir sensibilidade e especificidade em bons níveis conforme recomendado para o diagnóstico da infecção, além da possibilidade de diferenciar esta de outras arboviroses (OLIVEIRA, 2008; TAPPE et al., 2009).

Baseado nas vantagens e desvantagens das técnicas diagnósticas aqui revisadas e no impacto socioeconômico que a Febre Mayaro pode causar, o desenvolvimento de um método diagnóstico por imunofluorescência indireta, tendo como suporte de antígeno células recombinantes expressando a glicoproteína E2 de MAYV na membrana, traz uma alternativa viável para a melhoria das condições de diagnóstico da infecção por MAYV. Além disso, a obtenção biotecnológica do antígeno recombinante poderá gerar um teste mais econômico do 
que aqueles em que preparações virais são utilizadas e que, portanto, requerem dispendiosos procedimentos de manipulação e titulação viral.

Dessa forma, foram construídas linhagens de células S2 recombinantes capazes de expressar a glicoproteína E2 em condições de ser detectada em imunofluorescência indireta por anticorpos presentes em soro comercial de camundongos e em soro de pacientes infectados com MAYV.

As análises demonstraram que foi possível detectar, com eficiência e boa intensidade de fluorescência, anticorpos anti-E2 em amostras de soro humano tanto de fase aguda quanto covalescente para MAYV. Vale ressaltar que a detecção de anticorpos anti-E2 por IFI utilizando as células S2MtMAYV(E3E2), S2MtBipMAYV(E3E2) e linhagens, indica que o folding e transporte da glicoproteína E2 à membrana plasmática das células S2 foram realizados corretamente, tornando possível sua detecção. Como já foi descrito anteriormente, grande parte deste eficiente processamento ocorre por contribuição da proteína E3, a qual funciona como um peptídeo sinal para a translocação de p62 (precursora de E2) ao lúmen do retículo endoplasmático (LOBIGS; HONGXING; GAROFF, 1990). Por esta razão, a proteína E3 foi inserida no gene sintético utilizado na clonagem dos vetores plasmidiais pMtMAYV(E3E2) e pMtBipMAYV(E3E2V5), pois na ausência de E3 a glicoproteína E2 poderia não ser normalmente transportada, permanecendo retida no retículo (SNYDER; MUKHOPADHYAY, 2012). Esses dois vetores foram utilizados, pois por um lado procurouse prevenir uma possível falha de sinalização por parte da proteína E3 no sistema de células S2, incluindo um vetor contendo a sequência sinal de secreção da proteína Bip de Drosophila melanogaster, que seria capaz de direcionar a proteína E2 para o lúmen do RER. Além disso, as populações celulares obtidas com esse vetor dão origem a uma proteína E2 que contém uma cauda de poli-histidina, podendo facilitar, assim, a sua purificação futuramente.

Para realizar o desenvolvimento do procedimento de imunofluorescência de maneira mais rápida e confiável, iniciamos o trabalho de padronização utilizando células S2MtRVGPM3 que expressam a glicoproteína do vírus da raiva em sua membrana. Essas células já foram amplamente estudadas pelo nosso grupo (LEMOS, 2009; SANTOS et al., 2016) e estavam disponíveis no início do projeto, ao contrário das células expressando a proteína E2, que foram obtidas com o desenvolvimento do projeto. Dessa forma, um primeiro procedimento foi estabelecido (ANEXO I), tendo sido padronizados os processos de fixação, lavagem, marcação e montagem das lâminas. Essa abordagem também possibilitou a verificação da 
configuração necessária para o microscópio de fluorescência e sua condição de uso geral. Após o processo de padronização inicial, ficou demonstrado o potencial das células S2 em servir como suporte antigênico para uma glicoproteína viral de membrana. Também foi concluído que o método permitia a utilização de soro de animais imunizados como amostra a ser testada, e não apenas a utilização de anticorpos purificados, uma característica importante para o desenvolvimento do teste envolvendo a proteína E2 e amostras de soro humano. Além disso, o resultado obtido com o teste de temperatura de armazenamento de lamínulas contendo células $\mathrm{S} 2$ induzidas para a expressão da proteína de interesse e fixadas com solução Metanol/Acetona 1:1 mostrou que $-20{ }^{\circ} \mathrm{C}$ seria ideal para manter a morfologia celular, importante para a qualidade e nitidez da técnica de IFI, e permitir a detecção da proteína com boa intensidade de fluorescência. Esse resultado é particularmente importante quando se considera que o custo de equipamento freezer para manutenção de temperatura de $-20{ }^{\circ} \mathrm{C}$ é menor que aquele para $-80{ }^{\circ} \mathrm{C}$, sendo, portanto mais viável aos centros de diagnósticos.

Os bons resultados obtidos inicialmente com RVGP também foram observados com a proteína E2 de MAYV quando da análise de amostras humanas positivas para infecção pelo vírus Mayaro. A eficiência atingida na técnica para células S2 expressando a proteína de membrana de MAYV também foi decorrente da adaptação do protocolo de imunofluorescência indireta (ANEXO II) para utilizar quantidades reduzidas de anticorpos primários e secundários nas etapas de incubação e marcação, possibilitando boa qualidade de detecção de anticorpos em amostras de soro, com consequente diminuição do custo da técnica. Segundo DUAN et al., 2012, a redução nas quantidades de anticorpos gera maior sensibilidade e especificidade ao método, favorecendo a expansão da aplicação desta técnica na rotina diagnóstica.

Ainda que as populações S2MtMAYV(E3E2) e S2MtBipMAYV(E3E2) tenham inicialmente se mostrado aptas ao teste de imunofluorescência, realizamos três procedimentos de enriquecimento das populações celulares, buscando uma maior proporção de células positivas e uma maior intensidade de expressão: novo processo de seleção com antibiótico Higromicina B e seleções clonal e imunomagnética. Esses métodos resultaram na obtenção de linhagens que foram avaliadas quanto ao crescimento celular e quantidade relativa do mRNA da proteína E2, com o intuito de verificar o melhor ponto do cultivo para a retirada das células e montagem das lâminas. Todas as linhagens alcançaram altas concentrações celulares, conforme anteriormente descrito para células S2 (MCCARROL; KING, 1997; WURM, 
2004). As linhagens também apresentaram perfis de crescimento muito similares entre si, fator anteriormente observado com células S2 expressando RVGP após processos de enriquecimento populacional (SANTOS et al., 2016). A partir de 72 horas de indução da expressão (ou da adição de $\mathrm{CuSO}_{4}$ para a célula selvagem), o crescimento celular foi irregular e por vezes uma curta fase estacionária foi observada. De acordo com estudos anteriores com células S2, esse platô é considerado como uma possível forma de adaptação de células S2 à baixa concentração de oxigênio (hipóxia) (SWIECH et al., 2008). A alta densidade celular mantida mesmo após 10 dias de cultivo pode ser devido à característica do meio de cultura SF-900 ${ }^{\mathrm{TM}}$ III SFM $\left(\right.$ Gibco $^{\circledR}$ ) utilizado no experimento, o qual é otimizado para o crescimento de células de inseto. Nota-se também que as células transfectadas com o vetor pMtBipMAYV(E3E2V5), ao contrário das transfectadas com o pMtMAYV(E3E2), não apresentaram queda de viabilidade após 120 horas de indução. Teoricamente, a presença do sinal de secreção da proteína Bip de Drosophila apenas reforçaria a translocação do polipeptídeo E3E2 para o interior do RER, sendo imediatamente clivada após esse evento. Por outro lado, a expressão mediada pelo vetor contendo o sinal Bip também resulta em uma proteína E2 contendo cauda de poli-histidina (6x) em sua porção C terminal. Essas diferenças de construção genética não impactaram de forma perceptível na qualidade da proteína E2 expressa, tampouco em sua quantidade, segundo mostram os resultados. Também não houve diminuição da viabilidade celular nos tempos estudados, contrariamente ao que foi verificado para as construções em que E2 foi expressa em sua sequência original. Isso pode ser resultado de algum nível de citotoxicidade da E2 expressa em sua sequência original, dado que o início do declínio da viabilidade celular coincide com os tempos em que é observado seu acúmulo nas células (tempos após 120 horas de indução), como avaliado por IFI.

Para compreender melhor a expressão da glicoproteína E2 pelas linhagens celulares, realizamos um estudo cinético da quantidade do mRNA específico da E2 após a indução. Esse estudo se baseou em procedimentos anteriormente realizados para o estudo da cinética de expressão da glicoproteína da raiva em células S2 (ASTRAY et al., 2013; SANTOS et al., 2016). Foi observado que, de maneira geral, o mRNA de E2 apresentou níveis menores em tempos superiores a $120 \mathrm{~h}$ após a indução. Com base nos estudos anteriores citados (ASTRAY et al., 2013; SANTOS et al., 2016), esses resultados apontam uma maior atividade de tradução neste período e, por isso, maior expressão na membrana e menor quantidade do RNA mensageiro da E2. De fato, a mesma relação foi encontrada para a expressão da RVGP 
em células S2 (ASTRAY et al., 2013), de forma que a quantidade de mRNA relativo à RVGP diminuiu quando a quantidade da proteína aumentou, exatamente como ocorreu com as subpopulações de S2 expressando E2. Como mostrou o estudo já publicado que realizamos em paralelo (SANTOS et al., 2016, ANEXO III), a quantidade de mRNA é dificilmente relacionada com a quantidade da proteína recombinante expressa, de forma que, pelo menos em populações recombinantes com altos níveis de expressão do mRNA da proteína de interesse, grandes quantidades desse mRNA significam prioritariamente acúmulo e não se correlacionam com grandes quantidades da proteína recombinante. Para a linhagem S2MtMAYV(E3E2)_SC, os baixos valores de mRNA relativo encontrados desde o menor tempo pós-indução analisado (72 horas), quando comparados com os obtidos para as demais populações celulares, podem indicar que o gene da glicoproteína E2 esteja já em fase de tradução, sendo possivelmente o motivo por apresentar a marcação mais intensa em IFI. A aparente demora para que a E2 se torne detectável nas células S2 (144 horas), mesmo o RNA mensageiro estando presente horas após a indução da expressão, pode ser devido à necessidade do acúmulo da glicoproteína na membrana celular, ou ainda, devido a um processamento da glicoproteína mais demorado que o observado para RVGP nos estudos anteriores (SANTOS et al., 2016).

Finalmente, as linhagens celulares foram utilizadas para a avaliação de amostras clínicas obtidas através de doação de outros trabalhos. Amostras positivas para Mayaro são particularmente difíceis de serem encontradas e obtidas, justamente pelo fraco monitoramento existente para a ocorrência dessa doença. As amostras utilizadas neste trabalho são alíquotas de amostras de dois grupos de indivíduos diagnosticados positivamente para Mayaro, após terem sido descartados para malária, objetivo inicial do estudo para o qual foram coletadas.

A linhagem S2MtMAYV(E3E2)_SC foi escolhida para os teste de IFI utilizando amostras de indivíduos infectados por MAYV pois apresentou maior intensidade de fluorescência por célula quando incubada com soro hiperimune de camundongos, mesmo que a porcentagem de eventos marcados por campo não tenha sido substancialmente maior do que para a população S2MtBipMAYV(E3E2)_SC. Os resultados obtidos em IFI utilizando amostra de soro humano negativo para Alphavirus mostraram que não há ligação inespecífica às células S2MtMAYV(E3E2)_SC que foram utilizadas nos testes com soros positivos. Desta forma, soros de indivíduos infectados por Mayaro puderam ser testados e, conforme o esperado, apresentaram resultados bastante satisfatórios, com boa relação quanto à 
intensidade de fluorescência/célula e porcentagem de células fluorescentes/campo visual. Igualmente, as características morfológicas das células foram mantidas, sendo estes parâmetros observados tanto quando da incubação com amostras de fase aguda quanto de convalescência.

Da mesma forma, resultaram em marcação positiva os soros de indivíduos diagnosticados para Chikungunya, sendo já esperado algum grau de reação cruzada entre anticorpos contra MAYV e CHIKV por estes se tratarem de vírus participantes do mesmo gênero e complexo antigênico. Porém, seria necessário utilizar amostras de indivíduos infectados por Chikungunya em condição de convalescência e de indivíduos da mesma localidade sem histórico de infecção recente por CHIKV para embasar com maior segurança a conclusão de que o método não distingue infecção por MAYV ou CHIKV, o que não foi possível devido à indisponibilidade de um painel de amostras para Chikungunya e Mayaro. A presença de marcação na superfície de células VERO infectadas por ZIKV mostrou que a técnica de IFI poderia ser aplicada para o diagnóstico de infecção por esse vírus. Amostras positivas para DENV poderiam ser interessantes para verificar a ocorrência de reação cruzada com ZIKV.

Também foi possível concluir que o método diagnóstico aqui proposto poderia ser considerado futuramente para a substituição eficaz do teste EIA-ICC, utilizado em diversos locais do país, pois permitiu a detecção de anticorpos anti-E2 de MAYV em amostras de soro humano diluídas até 1:8000, maior diluição observada na técnica EIA-ICC. Foram detectados anticorpos em amostras de fase aguda e covalescente sem ocorrência de background e necessidade de manipulação do vírus Mayaro selvagem, o que se faz mais interessante do ponto de vista de biossegurança.

O material e o método desenvolvidos neste trabalho requerem ainda uma etapa de validação mais ampla, fazendo uso de um painel de soros positivos e negativos para arboviroses. Além disso, o material necessariamente precisaria ser produzido em condições de boas práticas para se tornar um produto. Por outro lado, a padronização do teste e sua utilização pelos laboratórios de diagnóstico tradicionais é uma condição mais direta que pode interessar. Aliás, para a detecção de anticorpos $\operatorname{IgM}$ ou IgG anti-CHIKV, respectivamente $52 \%$ e $58,7 \%$, de 54 laboratórios ao redor do mundo envolvidos em uma pesquisa de performance, utilizaram a metodologia de imunofluorescência, que em alguns casos foi desenvolvida localmente (JACOBSEN et al., 2016). Ainda segundo JACOBSEN et al., 2016, 
há uma dificuldade apresentada por diversos métodos de diagnóstico, incluindo a IFI, para a detecção de IgM contra CHIKV. No entanto, isso não foi encontrado neste trabalho durante a avaliação de reação cruzada entre MAYV e CHIKV, utilizando amostras de soro humano positivas (por RT-qPCR) para o vírus Chikungunya.

A validação da técnica diagnóstica diferencial, a partir de células S2, entre Alphavirus e Flavivirus permitiria um registro epidemiológico mais assertivo dos arbovírus Mayaro/Chikungunya e o tratamento mais adequado para o alívio das dores ocasionadas pela artralgia na fase crônica da infecção pelos mesmos. Em síntese, a linhagem S2MtMAYV(E3E2)_SC mostrou ser eficiente como suporte de antígeno à detecção de anticorpos anti-E2 do vírus Mayaro em amostras de soro humano e, futuramente, S2MtBipMAYV(E3E2V5)_SC poderá ser utilizada como fonte para a extração da proteína recombinante, o que permitirá sua aplicação para a pesquisa de anticorpos anti-Mayaro em outros tipos de testes diagnósticos. 


\section{CONCLUSÕES}

$\checkmark$ Um método de imunofluorescência baseado em células S2 foi padronizado com sucesso utilizando células S2MtRVGP-M3, tendo sido estabelecidos os melhores procedimentos para fixação de células, marcação com anticorpos purificados ou amostras de soro, etapas de lavagem e montagem das lâminas.

$\checkmark$ Foram obtidas, de forma eficaz, as células S2MtMAYV(E3E2), S2MtBipMAYV(E3E2V5) e linhagens após processos de clonagem, transfecção e seleção populacional.

$\checkmark$ Uma segunda etapa de padronização, utilizando células S2MtMAYV(E3E2) e S2MtBipMAYV(E3E2V5) permitiu melhorar o procedimento de imunofluorescência estabelecido, gerando economia de material.

$\checkmark$ Foi comprovado, por meio de ensaio de imunofluorescência indireta, que as células S2 são capazes de sintetizar com eficiência a glicoproteína E2 do MAYV.

$\checkmark$ As células S2 expressando E2 de MAYV apresentaram cinéticas de crescimento e de expressão do mRNA de E2 compatíveis com dados anteriores obtidos com células S2 expressando RVGP, reforçando as características do sistema descritas anteriormente pelo grupo de pesquisa.

$\checkmark$ A linhagem S2MtMAYV(E3E2)_SC obtida após seleção clonal se mostrou eficiente na expressão da glicoproteina E2 de membrana, permitindo a correta detecção de anticorpos $\operatorname{IgM}$ e $\operatorname{IgG}$ específicos no soro de indivíduos infectados com o vírus Mayaro.

$\checkmark$ O suporte antigênico S2MtMAYV(E3E2)_SC funcionou como um método diagnóstico diferencial entre Alphavirus/Flavivirus e é potencialmente sensível para substituir o teste EIA-ICC empregado no diagnóstico de infecção por Mayaro. 


\section{REFERÊNCIAS*}

AASKOV, J.G.; DAVIES, C,E,A. An immunofluorescence assay for human antibodies to Ross River virus. Journal of Immunological Methods, vol. 25, no. 1, p. 37-41, 1979.

ABAD-FRANCH, F. et al. Mayaro virus infection in Amazonia: a multimodel inference approach to risk factor assessment. PLoS Neglected Tropical Disease, vol. 6: e1846, 2012.

ACADEMIA BRASILEIRADE CIÊNCIAS. Doenças Negligenciadas. Ciência e Tecnologia para o Desenvolvimento Nacional. Estudos Estratégicos. Rio de Janeiro, 2010. 45 páginas.

AGGARWAL S. What's fueling the biotech engine?. Nature Biotechnology, vol. 25, no. 12, p. 1097-1104, 2007.

AMARAL, J.J.F. Avaliação de artigos científicos: Bases da epidemiologia clínica. Disponível em: 〈http://www.geocities.ws/abs5famed/avalcient.pdf>, 2007. Acesso em: 17 Out. 2014.

AMARAL NMF. Regulação da saída de mitose em células humanas - a função de hsMob1. 2010. Número total de folhas: 71.

Dissertação (Mestrado em Bioquímica) - Faculdade de Ciências, Universidade de Lisboa, Lisboa, Portugal, 2010.

AOKI, V. et al. Direct and indirect immunofluorescence. Anais Brasileiros de Dermatologia.; vol. 85, no. 4, p. 490-500, 2010.

ASSUNÇÃO-MIRANDA I. et al. Molecular Mechanisms Involved in the Pathogenesis of Alphavirus-Induced Arthritis. BioMed Research International, vol. 2013, no. 2013, 11 páginas, 2013.

ASTRAY RM et al. Kinetic studies of recombinant rabies virus glycoprotein (RVGP) cDNA transcription and mRNA translation in Drosophila melanogaster $\mathrm{S} 2$ cell populations.

Cytotechnology, vol. 65, no. 5, p. 829-38, 2013.

BOONPUCKNAVIG,S. et al. Indirect fluorescent antibody technique for demonstration of serum antibody in dengue hemorrhagic fever cases. American Journal of Clinical Pathology, vol. 64, no. 3, p. 365-371, 1975.

CAUSEY OR; MAROJA OM. Mayaro Virus: a new human disease agent. III. Investigation of an epidemic of acute febrile illness on the river Guama in Pará, Brazil, and isolation of Mayaro Virus as causative agent. American Journal of Tropical Medicine and Hygiene, vol. 6, no. 6, p. 1017-23, 1957.

*De acordo com:

ASSOCIAÇÃO BRASILEIRA DE NORMAS TÉCNICAS. NBR6023: informação e documentação: referências: elaboração. Rio de Janeiro, 2002. 
CAUSEY OR; THEILER, M. Virus antibody survey on sera of residents of the Amazon valley in Brasil. American Journal of Tropical Medicine and Hygiene,vol. 7, no 1, p. 36-41, 1958.

CHENG RH. et al. Nucleocapsid and Glycoprotein Organization in an Enveloped Virus. Cell, vol. 80, no. 4, p. 621-630, 1995.

CHERBAS L; GONG L. Cell lines. Methods, vol. 68, no. 1, p. 74-81, 2014.

DUAN Y. et al. A faster immunofluorescence assay for tracking infection progress of human Cytomegalovirus. Acta Biochim Biophys Sin, vol. 44, no. 7, p. 597-605, 2012.

EL MEKKI A. A., VAN DER GROEN G., PATTYN S. R. Evaluation of immunofluorescence and immunoperoxidase methods for antibody determination against Chikungunya, West Nile, and Yellow Fever viruses. Annales de la Societe Belge De Medecine Tropicale, vol. 59, no. 2, p.121-125, 1979.

FERNÁNDEZ-SALAS I. et al. Chikungunya and Zika Virus Dissemination in the Americas. Current Opinion in Infectious Diseases., vol. 29, no. 5, p. 467-475, 2016.

FERREIRA DF. et al. Weak bases affect late stages of Mayaro virus replication cycle in vertebrate cells. Journal of Medical Microbiology., vol.49, no. 4, p. 313-318, 2000.

FIGUEIREDO LTM. et al. Study oh two different enzyme immunoassays for the detection of Mayaro Virus antibodies. Memórias do Instituto Oswaldo Cruz, vol 84, no. 3, p. 303-307, 1989.

FIGUEIREDO MLG; FIGUEIREDO LTM. Emerging alphaviruses in the Americas:

Chikungunya and Mayaro. Revista da Sociedade Brasileira de Medicina Tropical, vol. 47, no. 6, p. 677-683, 2014.

FLORES, E.F. Virologia Veterinária. Santa Maria: UFSM., 2007. 598 p.

FRANCIS HL; KABEYA M; KAFUAMA N. et al. Comparison of sensitivities and specificities of latex agglutination and an enzyme-linked immunosorbent assay for detection of antibodies to the Human immunodeficiency virus in Africa sera. Journal of Clinical Microbiology, vol. 26, no. 11, p.2462-2464, 1988.

GUIA DE VIGILÂNCIA EPIDEMIOLÓGICA PARA CHIKUNGUNYA. SECRETARIA DA SAÚDE - BAHIA GOVERNO DO ESTADO. Disponível em: < http://www1.saude.ba.gov.br/entomologiabahia/photoartwork2/downloads/guia_ve_chik.pdf> Acesso em: 15 Ago. 2016.

HANAHAN D. Studies on transformation of Escherichia coli with plasmids. Journal of Molecular Biology, volume 166, no. 4, p. 557-580, 1983. 
JACOBSEN S et al. External quality assessment studies for laboratory performance of molecular and serological diagnosis of Chikungunya virus infection. Journal of Clinical Virology., vol. 76, p. 55-65, 2016.

JOHANSSON DX; DRAKENBERG K; HOPMANN KH; SCHMIDT A; YARI F; HINKULA $\mathrm{J}$; PERSSON MA. Efficient expression of recombinant human monoclonal antibodies in Drosophila S2 cells. Journal of Immunological Methods, vol. 318, no. 1-2, p. 37-46, 2007.

KRAEMER MUG et al. The global distribution of the arbovirus vectors Aedes aegypti and Ae. Albopictus. eLife, vol. 4, e08347, 2015.

LAVERGNE A. et al. Short communication Mayaro virus: Complete nucleotide sequence and phylogenetic relationships with other alphaviruses. Virus Research, vol. 117, no. 2, p. 283-290, 2006.

LELAND DS; GINOCCHIO CC. Role of Cell Culture for Virus Detection in the Age of Technology. Clinical Microbiology Reviews.; vol. 20, no. 1, p. 49-78, 2007.

LEMOS MAN. Construção e transfecção de vetores plasmidiais contendo o gene da glicoproteína do vírus da raiva (GPV) em células de Drosophila melanogaster. Número total de folhas: 82, 2009.

Dissertação (Mestrado em Biotecnologia).

LOBIGS, M; HONGXING, Z; GAROFF, H. Function of Semliki Forest Virus E3 Peptide in Virus Assembly: Replacement of E3 with an Artificial Signal Peptide Abolishes Spike Heterodimerization and Surface Expression of E1. Journal of Virology, vol. 64, no. 9, p. 4346-55, 1990.

LONG KC et al. Experimental Transmission of Mayaro Virus by Aedes aegypti. American Journal of Tropical Medicine and Hygiene., vol. 85, no. 4, p. 750-757, 2011.

MACS MILTENYI BIOTEC. Cell separation with MACS Technology: MACS Strategies. MACS Separators user manual - Miltenyi Biotec GmbH; páginas 2.2 - 2.2.1.2., 2011.

MARANGONI A. et al. Treponema pallidum Surface Immunofluorescence Assay for Serologic Diagnosis of Syphilis. Clinical and Diagnostic Laboratory Immunology, vol. 7, no. 3, p. 417-421, 2000.

MARCONDES CB; XIMENES MFFM. Zika virus in Brazil and the danger of infestation by Aedes (Stegomyia) mosquitoes. Revista da Sociedade Brasileira de Medicina Tropical, vol. 49, no. 1, 2015.

MENDONÇA JC; DOLCI JEL. Imunofluorescência para neuropeptídeos na mucosa nasal humana: avaliação de técnica para peptídeo intestinal vasoativo (VIP). Revista Brasileira de Otorrinolaringologia, vol.71, no.2, 2005.

PORTAL DA SAÚDE-SUS. MINISTÉRIO DA SAÚDE, 2016. Disponível em: $<$ http://portalsaude.saude.gov.br/index.php/o-ministerio/principal/leia-mais-o- 
ministerio/1205-secretaria-svs/vigilancia-de-a-a-z/febre-do-mayaro/20950-situacaoepidemiologica-dados >. Acesso em: 15 Set. 2016.

MORAES AM; AUGUSTO EFP; CASTILHO LR. Tecnologia do cultivo de células animais: de biofármacos a terapia gênica. São Paulo, Roca, 2007.

MOTA MTO; RIBEIRO MR; VEDOVELLO D; NOGUEIRA ML. Mayaro virus: a neglected arbovirus of the Americas. Future Virology, vol 10, no. 9, p. 1109 - 1122, 2015.

MUÑOZ M.; NAVARRO J. C. Virus Mayaro: un arbovirus reemergente en Venezuela y Latinoamérica. Biomédica, vol. 32, no. 2, p. 286-302, 2012.

NIEDRIG M et al. Evaluation of an Indirect Immunofluorescence Assay for Detection of Immunoglobulin M (IgM) and IgG Antibodies against Yellow Fever Virus. Clinical and Vaccine Immunology, vol. 15, no. 2, p. 177-181, 2008.

OLIVEIRA MS. ENAGIS-MAY: Uma proposta de ensaio de hemaglutinação indireta para detectar no sangue imunoglobulinas contra o vírus Mayaro. Número total de folhas: 80. 2008.

Dissertação (Mestrado em Ciências).

PFAFFL MW (2001) A new mathematical model for relative quantification in real-time RTPCR. Nucleic Acids Research, vol. 29, no. 9, e45, 2007.

PAUVOLID- CORRÊA A., et al. Neutralising antibodies for Mayaro virus in Pantanal, Brazil. Memórias do Instituto Oswaldo Cruz, vol. 110, no. 1, 2015.

PONCHIO L. et al. Mitomycin C as an alternative to irradiation to inhibit the feeder layer growth in long-term culture assays. Cytotherapy, vol. 2, no. 4, p.281-286, 2000.

POWERS AM., et al. Genetic relationships among Mayaro and UNA viruses suggest distinct patterns of transmission. American Journal of Tropical Medicine and Hygiene., vol. 75, no. 3, p. 461-469, 2006.

ROGERS SL; ROGERS GC. Culture of Drosophila S2 cells and their use for RNAi-mediated loss-of-function studies and immunofluorescence microscopy. Nature protocols, vol. 3, no. 4, p. $606-611,2008$.

SAIJO, M. et al. Immunofluorescence Technique Using HeLa Cells Expressing Recombinant Nucleoprotein for Detection of Immunoglobulin $G$ Antibodies to Crimean-Congo Hemorrhagic Fever Virus. Journal of Clinical Microbiology, vol. 40, no. 2, p. 372-375, 2002.

SANTOS, N. G. L. et al. Impact of recombinant Drosophila S2 cell population enrichment on expression of rabies virus glycoprotein. Cytotechnology, vol. 68, no. 6, p 1-7, 2016. 
SERRA, O. P. et al. Mayaro virus and dengue virus 1 and 4 natural infection in culicids from Cuiabá, state of Mato Grosso, Brazil. Memórias do Instituto Oswaldo Cruz, vol. 111, no. 1, p. 20-29, 2016.

STRAUSS, J. H.; STRAUSS, E.G. The Alphaviruses: Gene Expression, Replication, and Evolution. Microbiological Reviews, vol. 58, no. 3, p. 491-562, 1994.

SUHRBIER A.; LA LINN M. Clinical and pathologic aspects of arthritis due to Ross River virus and other alphaviruses. Current Opinion in Rheumatology, vol.16, no. 4, p. 374-379, 2004.

SNYDER, A. J.; MUKHOPADHYAY, S. The Alphavirus E3 Glycoprotein Functions in a Clade-Specific Manner. Journal of Virology, vol. 86, no. 24, p. 13609-20, 2012.

SWIECH, K. et al. Characterization of growth and metabolism of Drosophila melanogaster cells transfected with the rabies virus glycoprotein gene. Biotechonology and Applied Biochemistry, vol. 49, no. 1, p. 41-49, 2008.

TAPPE, D. et al. Ross River virus infection in a traveller returning from northern Australia. Medical Microbiology and Immunology, vol. 198, no. 4, p.271-273, 2009.

PROMEGA. pGEM®-T and pGEM®-T Easy Vector Systems. Technical Manual. Disponível em:

$<$ https://www.promega.com/ /media/files/resources/protocols/technical\%20manuals/0/pgemt\%20and\%20pgem-t\%20easy\%20vector\%20systems\%20protocol.pdf $>$. Acesso em: 10 Out. 2014.

TOIVANEN, A. Alphaviruses: an emerging cause of arthritis? Current Opinion in Rheumatology, vol. 20, no. 4, p. 486-490, 2008.

VASCONCELOS, P. F. C.; DA ROSA, A. P. A. T.; PINHEIRO, F. P. Evolutionary, ecological and taxonomic relationships between arboviruses of Florida, U.S.A., and Brazil . In: DA ROSA, A. P. A. T.; VASCONCELOS, P. F. C.; DA ROSA, J. F. S. T. (eds.). An overview of arbovirology in Brazil and neighboring countries. Belém: Instituto Evando Chagas, 1998. p. 71-99

WEAVER SC; REISEN WK. Present and Future Arboviral Threats. Antiviral Research, vol. 85 , no. 2, p. 328-45, 2010.

WURM, F.M. Production of recombinant protein therapeutics in cultivated mammalian cells. Nature Biotechnology, vol.22, no. 11, p.1393 - 1398, 2004.

ZUCHI N. et al. Molecular detection of Mayaro virus during a dengue outbreak in the state of Mato Grosso, Central-West Brazil. Memórias do Instituto Oswaldo Cruz, vol. 109, no.6, p.820-823, 2014. 


\begin{abstract}
ANEXOS
A Procedimento de imunofluorescência indireta utilizando células $S 2$ recombinantes como suporte antigênico
\end{abstract}

1- Inocular $3 \times 10^{6}$ células/mL em placas de 6 poços, contendo lamínulas estéreis.

2- Cultivar durante 1 dia e induzir com $\mathrm{CuSO}_{4}$.

3- Após 1 dia de cultivo, retirar o meio SF-900III.

4- Pipetar 1mL de PBS $1 \mathrm{X}$ nos poços para lavagem e homogeneizar cuidadosamente. Realizar a lavagem por três vezes no total.

5- Adicionar 1mL de solução de fixação (Metanol/Acetona 1:1 / FORMALDEÍDO $2 \%$ / FORMALDEÍDO $4 \%$ ) e deixar as placas a $-20{ }^{\circ} \mathrm{C}$ por 20 minutos.

6- Realizar três lavagens com PBS.

7- Aplicar $200 \mu \mathrm{L}$ do anticorpo primário sobre cada lamínula de acordo com a diluição padronizada. Incubar por 1 hora à temperatura de $4^{\circ} \mathrm{C}$.

8- Lavar três vezes com PBS 1X.

9- Após a lavagem, gotejar $200 \mu \mathrm{L}$ de anticorpo secundário em solução Azul de Evans sobre cada lamínula, na diluição de 1:500 para ambos. Incubar por 1 hora à temperatura de $4^{\circ} \mathrm{C}$.

10- Retirar o anticorpo secundário e lavar três vezes com PBS 1X.

11- Colocar $10 \mu \mathrm{L}$ de SlowFade-Gold antifade reagent sobre a lâmina, permitindo o posterior contato da lamínula com o reagente.

12- Analisar em microscópio de fluorescência. 
B Procedimento de imunofluorescência indireta utilizando células $S 2$ recombinantes como suporte antigênico (quantidades de anticorpos primários e secundários ajustadas)

Ao procedimento anteriormente padronizado foram adicionados os passos seguintes em substituição aqueles de 1 a 4:

1-) Induzir as linhagens celulares com $\mathrm{CuSO}_{4}$ por um período de 6 dias;

2-) Adicionar $40 \mu \mathrm{L}$ de células (concentração de, aproximandamente, $1,5 \times 10^{5}$ células totais) sobre as lamínulas, aguardar 40 minutos em estufa a $37^{\circ} \mathrm{C}$ e aplicar $20 \mu \mathrm{L}$ da solução de fixação Metanol/Acetona 1:1. Incubar por 20 minutos a $-20^{\circ} \mathrm{C}$ e lavar três vezes com PBS $1 \mathrm{X}$.

Os próximos passos seguem os anteriormente estabelecidos, porém com quantidades menores de anticorpos primário e secundário $(40 \mu \mathrm{L}$ dos mesmos diluídos). 
C Recombinant $S 2$ cell population enrichment impacts on specific RNA expression levels and on Rabies Virus Glycoprotein expression

Santos N.G.L., Rocca M.P., Pereira C.A., Ventini D.C., Puglia A.L., Jorge S.A.C., Lemos M.A.N., Astray R.M.

Nayara G.L. Santos, Mayra P. Rocca, Carlos A. Pereira, Daniella C. Ventini, Ana Lia P. Puglia, Soraia A.C Jorge, Marcos A.N. Lemos, Renato M Astray

Laboratório de Imunologia Viral, Instituto Butantan, Av. Vital Brasil 1500, 05503-900 São Paulo, Brazil 